Doktori (Ph.D.) értekezés

\title{
Plazmid DNS-alapú nanomedicína formuláció fejlesztése
}

\author{
LŐRINCZ ORSOLYA
}

Témavezető: Dr. Lisziewicz Julianna

Genetic Immunity Kft.

\section{KÖRNYEZETTUDOMÁNYI DOKTORI ISKOLA SZEGEDI TUDOMÁNYEGYETEM \\ Természettudományi és Informatikai Kar \\ Szeged}

2013 


\section{Tartalomjegyzék}

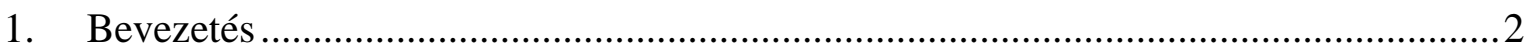

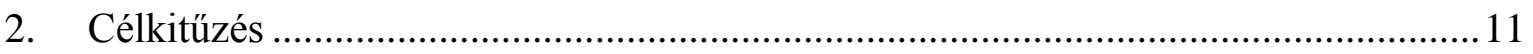

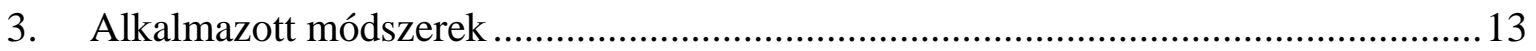

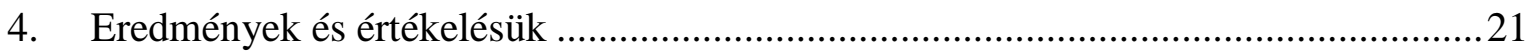

4.1. A DermaVir nanomedicína formuláció fejlesztése ..........................................21

4.1.1. A jelenlegi klinikai formuláció problémái....................................................21

4.1.2. A PEIm komponens optimalizálása............................................................23

4.1.3. A plazmid DNS komponens optimalizálása................................................28

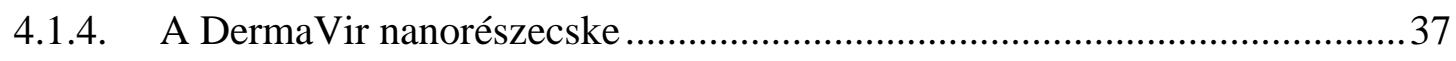

4.2. A DermaVir nanorészecske szerkezetének vizsgálata......................................57

4.2.1. A részecske kialakulásának nyomon követése ............................................57

4.2.2. A DermaVir nanorészecske szerkezete ....................................................6 61

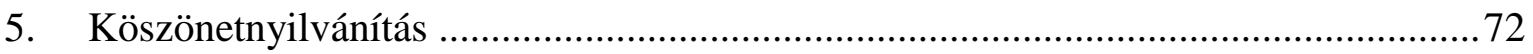

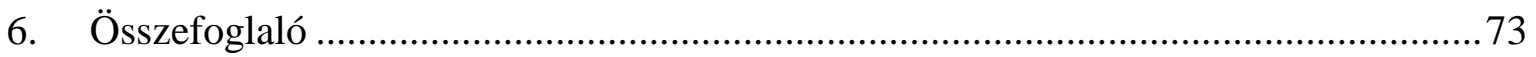

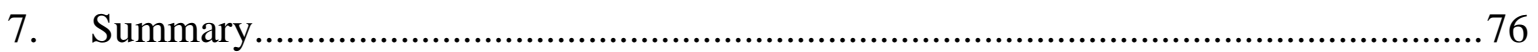

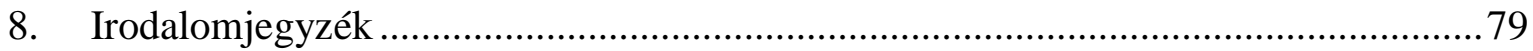




\section{BEVEZETÉS}

A nanotechnológia alkalmazása a gyógyászatban, valamint új gyógyszerek fejlesztésében egyre népszerübb tudományág, amelyet világszerte vizsgálnak. Az elmúlt két évtizedben, ahogy ma is hatalmas érdeklődés övezi a nanomedicína technológiákat, különösképpen a génterápiát és gének terápiás szándékkal való célzott eljuttatását meghatározott szövetekhez, sejtpopulációkhoz. Ezekben a nanogyógyszerekben a hatóanyag általában valamilyen nukleinsav; DNS, RNS, esetleg oligonukleotidok.

Legegyszerübb esetben a bejuttatni kívánt nukleinsavat önmagában, vektor használata nélkül alkalmazzák. ${ }^{1,2}$ Vektornak nevezzük azokat a molekulákat/ágenseket, melyek a bejuttatni kívánt hatóanyagot valamilyen kölcsönhatásnak köszönhetően (pl. ionos vagy kovalens kötés) képesek célzottan eljuttatni valamely sejtekhez a szervezetben. Azonban mind a célzás, mind a védelmi funkció hatásossága változó. Vektor használata nélkül az adminisztráció módja leggyakrabban elektroporáció, vagy intramuszkuláris injekció. ${ }^{3,4}$ Ezek a módszerek ugyan mutatnak némi hatékonyságot, de a nukleinsavak in vivo környezetben nagyon gyorsan degradálódnak, hiszen a szervezet igyekszik az idegen genetikai anyagot minél előbb semlegesíteni. ${ }^{5}$ Emellett a fenti módon alkalmazott vakcinák inkább antitestes immunválasz kiváltására alkalmasak, nem memória T-sejteket generálnak, így terápiás helyett inkább preventív céllal lehetnének alkalmazhatóak. ${ }^{6}$

Léteznek olyan nukleinsav-alapú vakcinák, melyekben gyengített, vagy módosított vírusokat használnak a sejtekbe való hatékony bejuttatáshoz. Ezen vírus vektorok előnye, hogy célzottan juttatják el a genetikai anyagot (vagyis a hatóanyagot) a kívánt sejtpopulációhoz. Emellett képesek megvédeni azt a szervezetben történő extra- és intracelluláris degradációtól. ${ }^{7,8,9}$ A vírus vektorok alkalmazása azonban rengeteg kérdést vet fel a termék biztonságosságával kapcsolatban, illetve sok esetben nem csak a kívánt betegség ellen váltanak ki immunválaszt, hanem maga a vektor, az alkalmazott gyengített vírus ellen is, emiatt az ismételt alkalmazás, többszöri dózis sem hozza meg a kívánt eredményt, hisz a vektort magát már semlegesíteni igyekszik a szervezet. ${ }^{10,11}$ Emellett az ilyen termékek reprodukálható gyártása és minőségellenőrzése is nagy kihívást jelent. ${ }^{12}$ 
Fontos megemlíteni a liposzóma nanorészecskéket, vagyis lipoplexeket, melyek szintén nagyon népszerủek ezen a tudományterületen. Ezeket a részecskéket általában többféle foszfolipid és lipid láncok keveréke alkotja, a hatóanyag pedig általában valamilyen nukleinsav vagy oligonukleotid. ${ }^{13}$ Előnyük, hogy a szervezet képes lebontani őket (biodegradábilisak) illetve meglehetősen szük és reprodukálható részecskeméreteloszlással állíthatók elő. Azonban a biodegradábilitás miatt nagyon gyorsan kiürülnek a szervezetből, illetve nem képesek célzottan a hatóanyag bejuttatására, mivel nem tartalmaznak olyan felületi elemeket, amelyek specifikusan tudnának célozni bizonyos sejteket. ${ }^{14,15}$ A liposzómák képződése bonyolult folyamat: megfelelő körülmények között bizonyos foszfolipidek (pl. lecitin) vizes közegben kettős, vagy többszörös rétegekbe rendeződnek, leggyakrabban ultrahangos kezelés hatására. ${ }^{16}$ Az ultrahangos módszer azonban könnyen kárt tehet a „becsomagolni” kívánt hatóanyagban.

A nanomedicínák legnagyobb részben plazmid DNS (pDNS) alapú formulációk, melyekben az aktív hatóanyag egy vagy több plazmid DNS. A molekuláris biológiában a plazmid DNS olyan DNS-t jelent mely a kromoszómális DNS-től elkülönül, és attól függetlenül tud replikálódni. ${ }^{17}$ A pDNS-t sok esetben az immunválasz sikeres kiváltása érdekében szintetikus vektor (valamilyen polimer) segítségével úgynevezett nanorészecskévé tömörítenek. Az ilyen polimerek felülete tetszés szerint módosítható különböző molekulák segítségével, így specifikusan célozhatók a szervezet immunsejtjei. ${ }^{18,19,20}$ Ezek a nanorészecskék, vagy poliplexek másik fontos tulajdonsága, hogy a kórokozók néhány száz nanométeres mérettartományába esnek. Az ilyen vakcinákban a pDNS a betegségre specifikus antigéneket kódol, melyeknek a megfelelő sejtekben (antigén prezentáló sejtek) való kifejeződése biztosítja az immunválasz létrejöttét, vagyis a szervezet saját védekező mechanizmusát kihasználva érhetünk el gyógyulást úgynevezett immunterápia segítségével. A vektornak alkalmas polimerek tárháza rendkívül széles: poliészterek, poliaminosavak, poliuretánok, polisavak homo- és heteropolimerjei mind megfelelök. ${ }^{21,22,23,24}$

A tudományos irodalomban elfogadott tény, hogy a negatív töltésű pDNS pozitív töltésű polimerekkel (polikationokkal) spontán módon, önrendeződő nanorészecskéket képez. ${ }^{25,26,27,28,29}$ Egy ilyen, széles körben vizsgált szintetikus vektor az egyenes láncú polietilénimin (PEI), melyben a molekula pozitív töltésű szekunder aminjai ionos kötést létesítenek a pDNS negatív töltésű foszfátcsoportjaival. A PEI ötvözi a vírus vektorok és a 
liposzómák előnyeit, viszont megbirkózik azok főbb hátrányaival. ${ }^{30,31,32,33}$ A PEI váza kémiailag könnyen módosítható, hogy különböző felületü nanorészecskéket kapjunk, így a vírusokhoz hasonlóan képes lehet specifikusan célozni bizonyos sejteket, emellett a szervezetben nem alakul ki ellene immunválasz, hasonlóan a liposzómákhoz. ${ }^{19}$ A PEI-t az egyik leghatékonyabb szintetikus vektorként jegyzi az irodalom mind oligonukleotidok, pDNS és siRNS (short interfering RNS) szállításához. ${ }^{34,35,36,37}$ Kétfajta morfológiai formája az elágazó láncú, úgynevezett „,branched” PEI (b-PEI) és az egyenes láncú lineáris polimer (1-PEI). A b-PEI-t az aziridin sav-katalizált polimerizációjával szintetizálják, míg a lineáris változatnál a monomer általában valamilyen 2-szubsztituált oxazolin származék, majd a polioxazolinból savas hidrolízissel állítják elő a terméket. ${ }^{38,39}$ Mind a lineáris, mind az elágazó láncú PEI képes megvédeni a pDNS-t az enzimatikus és egyéb biokémiai támadásoktól, köztük a sejtbe való bejutást követően az endoszóma alacsony pHjától. ${ }^{40,41,42}$ A nem protonált nitrogének ugyanis képesek pufferelni a protonpumpák hatását. Ezt a tulajdonságot nevezzük proton-spongya jelenségnek. A kétféle polimerrel a pDNS azonban eltérő fizikokémiai tulajdonságú poliplexeket képez. Lineáris PEI-vel létrejövő nanorészecskék aggregálódnak a sejtmembrán környezetében, ezzel ellentétben a b-PEI/pDNS részecskék még a citoplazmában is diszkrét részecskékként vannak jelen a sejtbe való bejutás után. ${ }^{43,44,45}$ A b-PEI dendrimer szerkezete a 1-PEI lineáris láncával szemben sokkal kompaktabb nanorészecskét képez, amely kevésbe hatékony a pDNS sejtekbe való bejuttatásában, és sokkal magasabb toxicitást mutat, mivel a sejt nehezen tudja lebontani. ${ }^{46,47}$ PEI tartalmú poliplexeket sikeresen alkalmaztak állatkísérletekben a tüdő, a máj illetve az agy in vivo célzásához. ${ }^{30,48,49,50}$ A közvetlenül a tumorba való beinjektálás során pedig azt találták, hogy ott hosszan képes tartózkodni a poliplex, így biztosítva a folyamatos génexpressziót. ${ }^{51}$ Egy másik antitumor kísérletben sikeresen szorították vissza a tumor növekedését és növelték a túlélést humanizált májrákos egérmodellben PEI/pDNS komplexeket használva. ${ }^{52}$ Emberekben is ígéretes klinikai vizsgálatok folynak jelenleg is PEI/DNS nanorészecskék alkalmazásával. Ilyen például egy hasnyálmirigy adenokarcinoma elleni génterápia, ami jelenleg fázis I-es vizsgálat alatt van, miután hörcsög modellben kimutatták, hogy a kétféle kinázból alkotott fúziós génből és a PEI-ből kialakuló nanorészecske kemoterápiával közös alkalmazása a daganat zsugorodását okozza. ${ }^{53,54}$ Szintén fázis I-es klinikai vizsgálatban bizonyította biztonságosságát és tolerálhatóságát egy olyan interleukin-12-t kódoló plazmid DNS és PEI-származék nanorészecskéje, ahol a polimert polietilén-glikol és koleszterol 
felhasználásával módosították. ${ }^{55}$ Ezt a terápiát visszaeső petefészekrákban szenvedő páciensekben tesztelték, akik a kemoterápiára rezisztensnek bizonyultak.

A plazmid DNS-alapú vakcinák egyik nagy problémája a célzott bejuttatás mellett a stabilitás kérdése. Ugyan a lipoplexek sok esetben akár hónapokig eltarthatók $4^{\circ} \mathrm{C}$-on oligonukleotidokkal, pDNS-sel formulálva már nem. ${ }^{56,57,58}$ A PEI és egyéb szintetikus polimerekkel készülő poliplexek pár óránál tovább nem stabilak, legtöbb esetben a részecskék dezintegrálódnak, vagy a folyamatos aggregáció miatt fokozatosan kiülepednek, kicsapódnak. ${ }^{59}$ Egy másik jellemző probléma az ilyen biológiai rendszereknél, hogy gyakran kémiai szempontból nem vizsgálják a rendszereket, vagyis a biológiai laborokban bevált szokásos ,adalékanyagokat”, reagenseket, puffereket használják, anélkül, hogy vizsgálnák, van-e/lehet-e valamilyen kémiai összeférhetetlenség az anyagok között. Ilyen például a Tris, Tris-EDTA (TE), vagy EDTA tartalmú Tris-acetát (TAE) pufferek, illetve akár az egyszerü fiziológiás só- vagy glükóz/dextróz oldat, amelyek minden laborban kéznél vannak, és amelyek ugyan a „csupasz” pDNS-t általában valóban stabilizálják, de a poliplex rendszer egészét tekintve nem szerencsés választás egyik sem, ha meggondoljuk, hogy milyen mellékreakciók jöhetnek létre. ${ }^{60,61}$

Amint az ilyen új-generációs pDNS-alapú nanomedicínák fejlesztése előrehalad, számos feltételnek kell megfelelniük a hatékonyság és a biztonságosság mellett, hogy valóban piacképes termék váljon belölük. ${ }^{62} \mathrm{Az}$ ilyen, polimer vektort tartalmazó, formulációk instabilitása miatt sokszor csak közvetlenül a kezelés előtt lehet több komponensből összekeverni a készítményt. ${ }^{63}$ Az egyik lehetséges megoldás a stabilitás kérdésére a részecske-szuszpenzó liofilizálása lehetne, azonban korábbi kísérletek azt mutatták, hogy a lineáris PEI-t tartalmazó formulációk nem liofilizálhatók (pontosabban liofilizálás után nem oldhatók vissza), annak ellenére, hogy az elágazó láncú PEI-vel ez a probléma nem jelentkezik. ${ }^{64,65,66}$

Az AIDS halálos „betegségét” (Acquired Immune Deficiency Syndrome, vagyis szerzett immunhiányos tünet együttes) a HIV (Human Immunodeficiency Virus, vagyis emberi immunhiány vírus) okozza. 1983-ban a Pasteur Intézetben izoláltak egy vírust (többek között Françoise Barré-Sinoussi és Luc Montagnier), melyről úgy gondolták, hogy az AIDS-et okozza. ${ }^{67}$ Ebböl az izolátumból küldtek mintát a CDC intézetbe (Center for Disease Control), majd néhány hónappal később a vírust elnevezték limfadenopátiával 
összefüggő vírusnak, vagyis LAV-nak és mintát küldtek a National Cancer Institute-nak is. 1984-ben Washingtonban bejelentették, hogy Robert Gallo sikeresen izolálta a vírust, amely az AIDS-et okozza, melyet HTLV-III-nak neveztek el. Egy mindenki által elérhető vértesztet is kidolgozott, amely közel $100 \%$-os pontossággal kimutatja a fertőzést. ${ }^{68}$ Csak 1985-re derült ki, hogy a két vírus valójában egy és ugyanaz. ${ }^{69}$ Ugyanebben az évben kezdték meg a véradó központokban használni a kifejezetten HTLV-III/LAV vírus specifikus tesztet, és a pozitív páciensek többé nem adhattak vért. A vértesztek által lehetővé vált a vírus klónozása és genetikai anyagának meghatározása. A vírus végül 1986-ban kapta meg a HIV nevet. ${ }^{70}$ A HIV vírus és az AIDS közötti kapcsolat felfedezésért Françoise Barré-Sinoussi és Luc Montagnier kapta meg a Nobel-díjat, azonban fontos megjegyezni, hogy Gallo felfedezései nélkül ez lehetetlen lett volna. ${ }^{71}$

Ma a HIV-fertőzés és az AIDS az egyik legnagyobb egészségügyi kihívás. Jelenleg több mint 30 millió HIV-fertőzött él a világon, akik közül mindössze kb. 5 milliót kezelnek a ma elérhető gyógyszeres terápiával. ${ }^{72}$ A fertőzöttség jelenleg Kelet-Európában gyorsabban terjed, mint Afrikában, és növekedést mutat Európa nyugati részén is. A vírusellenes gyógyszerek forradalmasították ugyan a fertőzés kezelését, de csak az AIDSbetegség késleltetett kialakulását érik el, gyógyulást nem hoznak. A hosszú távú kezelés azonban együtt jár az alkalmazás során fellépő toxicitással, rengeteg kellemetlen mellékhatással, és a beteg előbb-utóbb rezisztenssé válik az alkalmazott szerekre, ami azt jelenti, hogy mindig újabb és újabb antiretrovirális gyógyszereket kell kapnia. Emiatt nagy hangsúlyt fektetnek ma is sokan a megfelelő ellenszer (preventív vagy terápiás) megtalálására. A DermaVir nanomedicína ezekkel a gyógyszerekkel ellentétben egy innovatív immunterápiás termékjelölt, amely jelenleg HIV/AIDS ellenes terápiás vakcinaként fázis II-es klinikai vizsgálatokban vesz részt és ezzel ezen a területen a legelőrehaladottabb stádiumban van a pDNS alapú nanomedicínák között. ${ }^{73}$ A DermaVir aktív hatóanyaga egy plazmid DNS, amely a HIV vírus 15 fehérjéjét kódolja, így képes kiváltani HIV-specifikus immunválaszt a pDNS-ben kódolt antigének kifejeződésével. ${ }^{74,75,76}$ A kódolt proteinek olyan biztonsági módosításokkal vannak ellátva, melyeknek köszönhetően a termék akár egészséges embereknek is beadható, nem képes integrálódni a humán kromoszómába és a reverz transzkripció is gátolt. ${ }^{77}$ Hatékony antigén expresszióhoz a pDNS-t egy „patogén-szerü” nanorészecskévé formuláljuk glükóz/dextróz oldatban egy mannobiozilált lineáris polietilénimin (PEIm) polimer 
segítségével. ${ }^{78}$ A két fö komponenst egyszerüen összekeverve, közöttük elektrosztatikus kölcsönhatás alakul ki (1. Ábra), és a pozitív töltésü PEIm nanorészecskévé „csomagolja össze" (kondenzálja) a negatív töltésü pDNS-t. A PEIm kationos jellege abból fakad, hogy mivel a polimer önmagában nem oldódik vízben, annak hidroklorid sóját használjuk, vagyis a szekunder aminok egy része protonált-, kationos formában van. Az ionos jellegü kötés tehát a pDNS foszfát csoportja és a PEIm szekunder amin csoportja között jön létre.

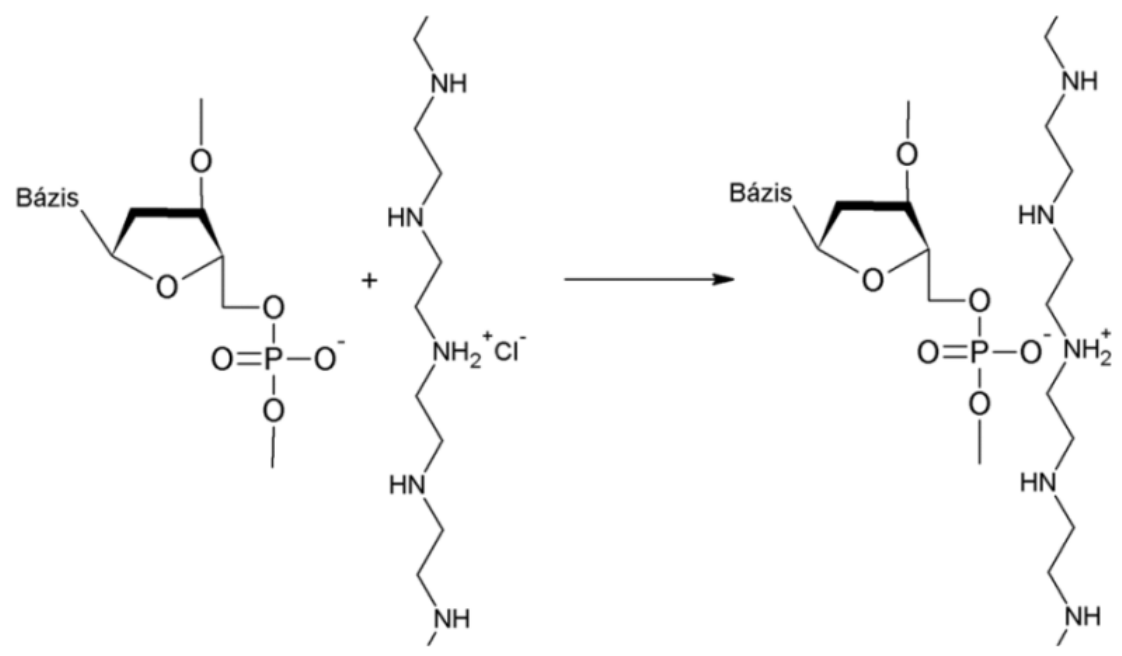

1. Ábra. Plazmid DNS és PEIm között kialakuló ionos kötés sematikus ábrája.

A PEIm-hez kovalensen kötött mannobióz molekulák azt a célt szolgálja, hogy a vírusokhoz, kórokozókhoz hasonlóan a részecskének „patogén-szerü” külsőt kölcsönözzenek, ugyanis azok felületén is gyakran találhatók glikoproteinek, vagy egyéb cukorszerü részek. ${ }^{79} \mathrm{~A}$ mannobióz emellett azért is szerencsés, mivel a célozni kívánt sejtek, a szervezet epidermális Langerhans-sejtjei rendelkeznek mannóz-receptorral, ami elösegítheti a sejtbe való bejutást. ${ }^{80}$

A pDNS és a PEIm összekeverésével kapott folyadék formulációt, a „patogénszerü” nanorészecskék szuszpenzióját a nyirokcsomók célzásához transzdermális úton alkalmazzuk a DermaPrep tapasz segítségével, amely kihasználja a szervezet természetes védekező mechanizmusát. ${ }^{81}$ Ezt a természetes folyamatot használták ki ugyancsak a himlőelleni védőoltás „karcolásos” adminisztrációjával is, amely hazánkban is egészen az 1980es évek elejéig zajlott és bizonyítottan az egyik leghatásosabb módszer a hosszú távú, 
memória T-sejtes immunválasz kiváltásához. ${ }^{82}$ (Mi sem nagyobb bizonyíték erre, minthogy a himlő az egyetlen olyan kórokozó, amelyet sikeresen kipusztítottak a világon.) A tapasz alkalmazása 3 fő lépésből áll: (1) az alkalmazás helyén a bőr megfelelő előkészítése, (2) a tapasz felragasztása, (3) a folyadék formuláció befecskendezése a tapasz alá, a féligáteresztő hártya és a bőr közé.

Először tehát a bőrön enyhe epidermális „sérülést” okozunk egy szivacs segítségével, így részlegesen „megbontjuk” a bőr felső, elszarusodott rétegét, a stratum corneumot (ez a gyakorlatban annyit jelent, hogy egy keményebb szivaccsal való dörzsöléssel enyhe bőrpírt okozunk). ${ }^{76} \mathrm{~A}$ bőr előkezelése után felragasztjuk a tapaszt, amely tulajdonképpen egy zseb-forma, csak a peremén ragad a bőrhöz, és kizárólag arra szolgál, hogy az aláfecskendezett folyadék formulációt az előkészített bőrfelületen tartsa. A DermaVir nanomedicína hatásmechanizmusát a 2. Ábra foglalja össze:

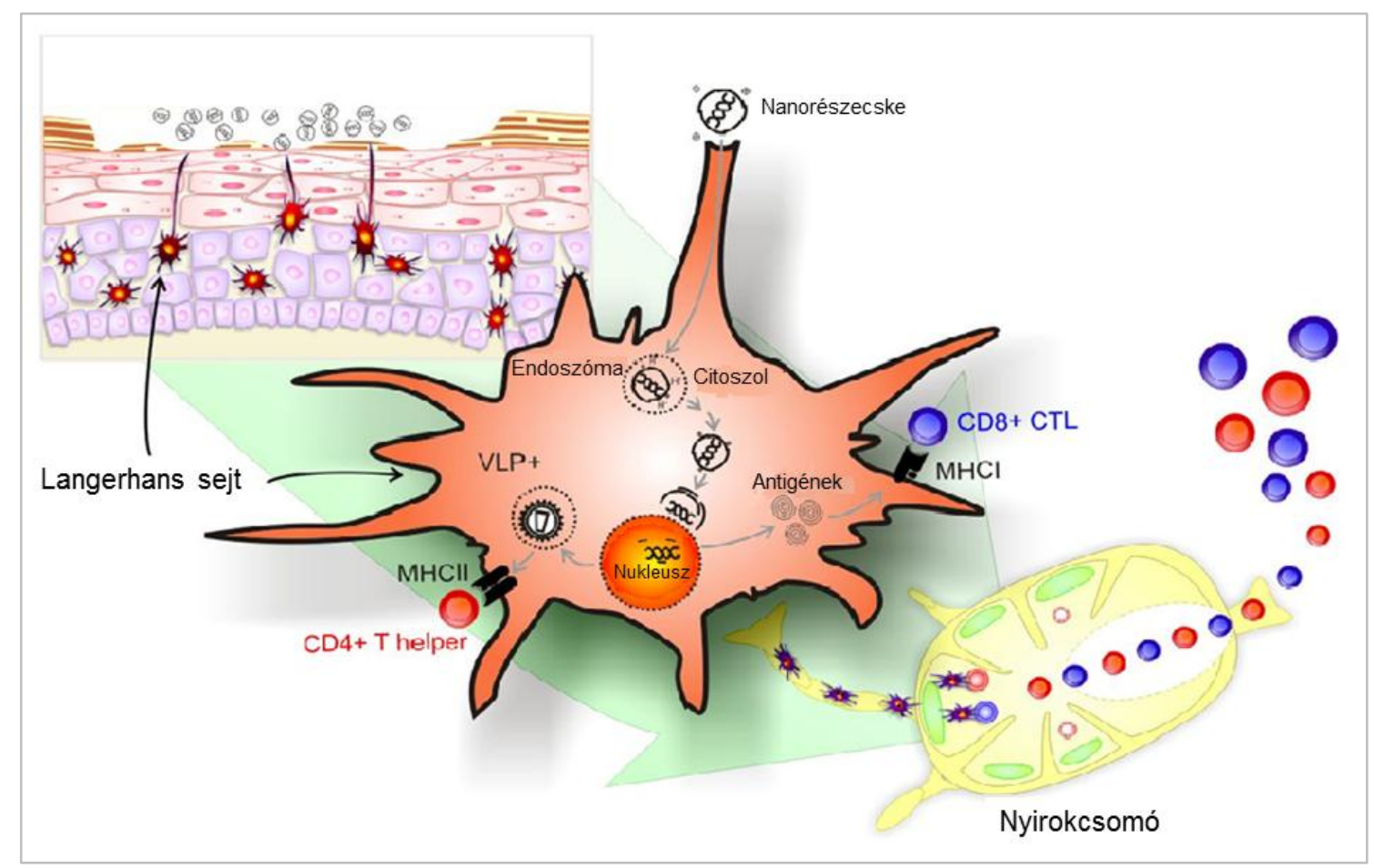

2. Ábra. DermaVir nanomedicína hatásmechanizmusa.

A mechanizmus: 
1. Az első lépés a Langerhans-sejtek (LC) specifikus célzása. Ezek a sejtek antigén prezentáló sejtek, melyek az egész epidermiszt behálózzák, és akkor aktiválódnak, mikor valamilyen sérülés éri a bőrt. ${ }^{83,84,85}$ Ekkor nyúlványaik segítségével felkúsznak a felszínre és felvesznek minden testidegen, patogén-szerű részecskét. Ahhoz, hogy a bejuttatni kívánt részecskét kórokozónak lássa a szervezet, a megfelelő részecskeméret mellett arra van szükség, hogy a felületén patogén-szerü elemek legyenek. Azért, hogy a pDNS/PEI nanorészecske célzottan eljusson a szervezet antigén prezentáló sejtjeihez (LC-k), a polimert módosítottuk azáltal, hogy cukormolekulával konjugáltuk, mannobiózt kötöttünk rá, ezáltal patogén-szerủvé téve a kialakuló részecskét. ${ }^{86}$

2. A második lépés a sejtbe való bejutás. Ehhez a megfelelő részecskeméret szükséges. A sejtek többféle mechanizmussal vehetnek fel anyagokat, részecskéket. Ezek közül a DermaVir számára a legmegfelelőbb az endocitózis, mivel majd ez biztosítja a megfelelő processzálást sejten belül. ${ }^{87,88}$ Ehhez az ideális mérettartomány az 50-400 nm. ${ }^{89}$ A DermaVir nanorészecske átlagos hidrodinamikai átmérője 100 és $300 \mathrm{~nm}$ között van, így beleesik az ideális, vírus mérettartományba. Miután a Langerhans-sejt felvette a részecskét és aktiválódott, elindul a legközelebbi nyirokcsomó felé.

3. A sejten belüli processzálás. A sejtbe receptoron keresztül bejutott anyagot a sejt endoszómába zárja, amelyben proton pumpa segítségével elkezdi csökkenteni a pH-t, hogy lebontsa a felvett idegen anyagot. ${ }^{90}$ Ahhoz, hogy a bejutott részecske túlélje az egyre csökkenő pH-t, arra van szükség, hogy képes legyen pufferelni a megnövekedett protonmennyiséget. A PEIm a proton-spongya jelenségnek köszönhetően képes megvédeni a pDNS-t az endoszómális degradációtól, így az el tud jutni a sejten belül a sejtmagig anélkül, hogy károsodna. A sejtmag közelében azonban a részecskének szét kell esnie ahhoz, hogy a pDNS bejuthasson a sejtmagba, és a benne kódolt információk átíródhassanak, megkezdődhessen a génexpresszó. ${ }^{91,92}$

4. Az antigének expressziója. Miután a pDNS bejutott a magba és átíródott a kódolt információ, megkezdődik a fehérjék kifejeződése. A DermaVirben használt pLWXu1 pDNS a HIV vírus 15 fehérjéjét kódolja, biztonsági mutációkkal módosítva, ahol szükséges (pl. csonkított reverz transzkriptáz és integráz gének). ${ }^{77}$

5. Antigén prezentáció a nyirokcsomóban, a T-sejtek aktiválása és immunválasz. Az antigén prezentáció két úton történhet: az expresszált fehérjék összeszerelődhetnek „vírus- 
szerű részecské”-vé (VLP-vé, ami nem összekeverendő a patogén-szerü nanorészecskével), így a 'Major Histocompatibility Complex' (MHC) II-es receptoron bemutatva $\mathrm{CD}^{+}{ }^{+}$-es T-sejtek jönnek létre, vagy a fehérjéket összeszerelődés nélkül MHC Ies receptoron keresztül mutatja be a sejt a naiv T-sejteknek és $\mathrm{CD}^{+}$-as ölösejtek proliferálódnak. Mindkét úton a HIV vírusra specifikus memória T-sejtes immunválasz alakul ki. ${ }^{77}$ Ezek a citotoxikus sejtek ezután elindulnak a nyirokcsomóból és a szervezetben keringve irtják a fertőzött sejteket.

Ez a fajta immunterápia platform technológiára alkalmas, ugyanis a pDNS konstrukt változtatásával más vírus-, baktériumfertőzések, rák-, vagy akár allergiás megbetegedések ellen is alkalmazható. ${ }^{93}$ 


\section{CÉLKITÜZÉS}

A DermaVir klinikai vizsgálati készítmény jelenleg három különböző komponensből készül közvetlenül a kezelés elött, a klinikán. Ezt a három komponenst három különbözö hőmérsékleten tároljuk; a pDNS-t $-80^{\circ} \mathrm{C}$-on, a PEIm-et $-20^{\circ} \mathrm{C}$-on és a glükóz/dextróz oldatot szobahőmérsékleten $\left(25^{\circ} \mathrm{C}\right)$. A fázis I és II klinikai vizsgálatok során ezeket standard müveleti elöírás szerint a klinikai gyógyszerész előkészítette, összekeverte, majd azt 3 órán belül fel is kellett használnia a termék glükóz oldatban való instabilitása miatt. Ez a bonyolult, gyógyszerészt és nem hétköznapi klinikai felszerelést (ultramély-hütő) igénylő formuláció nehezen lenne piacképes, ezért a cél egy olyan formuláció kidolgozása, amiben a pDNS/PEIm nanorészecske stabilan eltartható, használata nem igényel klinikai gyógyszerészt, elegendő a kórházi nővér a kezeléshez. A DermaVir nanomedicína kitünő biztonságosságot mutatott fázis I-es és II-es klinikai vizsgálatokban HIV-fertőzött egyedekben, azonban bármilyen hatásos is egy vakcina, a formuláció nehézkes alkalmazása és különleges tárolási igényei nagyban megnehezítik egy piacképes termék megszületését. ${ }^{94,95,96}$

Azt sem szabad figyelmen kívül hagyni, hogy mivel a készítmény már túl van a szükséges biztonságossági és toxikológiai vizsgálatokon, ezért a gyógyszerengedélyeztetési hatóságok csak olyan változtatásokat engednek meg a meglévő formuláción, melyek egyértelműen nem befolyásolják ezeket a tulajdonságokat, ellenkező esetben a termék klinikai vizsgálata és így engedélyeztetése akár évekkel elhúzódhat. Így a DermaVir nanomedicína formuláció optimalizálásának folyamata során a fejlesztés lehetőségei meglehetősen szük keretek között mozoghatnak.

A formuláció fejlesztésénél tehát a komponensek külön-külön való vizsgálata és a rendszerben való együttes, egymásra való hatásának megismerése is cél, hogy olyan formába önthessük a nanomedicínát, mellyel a fázis III klinikai vizsgálatokat megkezdheti. Ennek elengedhetetlen követelménye a korábbi biológiai aktivitás megőrzése és a termék stabillá tétele. Fontos szem előtt tartani, hogy mind az európai, mind az amerikai gyógyszer-engedélyeztető hatóságok előírása szerint a fázis III-as klinikai vizsgálati készítménynek meg kell egyeznie azzal a formulációval, amely az engedélyeztetés után a piacra kerül. 
További cél a DermaVir nanomedicína szerkezet-biológiai aktivitás kapcsolat felderítése, mivel a nanotechnológiának ez a része új tudományterület. 


\section{Alkalmazott MóDSZerek}

Minden kísérletet legalább egyszer megismételtünk, legtöbb esetben kétszer. A kísérletek nagy részében három párhuzamos mintával dolgoztunk, kivéve az in vitro biológiai aktivitás vizsgálatot, ahol a replikátumok száma öt. A felhasznált reagensek mind gyógyszerkönyvi minőségüek, ahol ez nem elérhető, ott analitikai tisztaságúak.

Statisztikai analízis a Student’s T-próbával történt. A különbség minden esetben szignifikáns, amennyiben a p érték <0,05.

\section{Nanorészecskék előállítása}

A nanorészecskéhez használt pDNS a pLWXu1 konstrukt, amely 12,5 kilóbázispárból $(\mathrm{kBp})$ áll és $1 \mathrm{mg} / \mathrm{ml}$ koncentrációjú vizes oldatban, $-80^{\circ} \mathrm{C}$-on tároljuk. Ez a koncentráció 3,23 mM-t jelent a foszfátra nézve. A használt PEIm 22 kDa nagyságú polimer (a mannobiózzal és a kötött hidrokloriddal együtt $\sim 32,8 \mathrm{kDa}$ ), amelyet $-20^{\circ} \mathrm{C}$-on tárolunk 13,6 mM-os moláris koncentrációban a nitrogénre nézve. A polimer a nitrogénhez képest 3mó1\% mannobiózt tartalmaz. A semleges polimer vízben nem oldódik, csak annak hidroklorid sója, így minden esetben ezt használjuk a nanomedicína összetevőjeként. A nanorészecske készítése az alábbiak szerint történt: egy térfogat $1 \mathrm{mg} / \mathrm{ml} \mathrm{pDNS}$ oldatot kihígítunk 3 térfogatnyi formulációs oldószerrel, majd ugyanígy egy térfogat 13,6 mM PEIm oldatot is kihígítunk 3 rész formulációs oldószerrel, végül a kihígított pDNS 1 térfogatnyi oldatához adunk a kihígított PEIm oldatából 1 térfogatnyit. A két oldat összekeverésével a nanorészecskék spontán kialakulnak, a komponensek mól aránya, vagyis a nitrogén-foszfor arány (N/P) 4,2 lesz, az egyszerüség kedvéért ezt 4-re kerekítve használom a leírásokban. Az oldószer a jelenlegi klinikai formulációban 10 tömeg\% glükóz/dextróz oldat. A kísérletek megkezdése előtt, az elkészítés után 20 percig inkubáltuk a folyadék formulációt a labor hőmérsékletén $\left(25 \pm 3^{\circ} \mathrm{C}\right)$.

Néhány kísérletben nem a HIV fehérjéket kódoló, hanem más pDNS konstruktokat (is) használtunk. Ezek: 
- pRED plazmid (6,5 kBp), vörös fluoreszcens proteint kódol, 1 mg/ml koncentrációjú vizes oldatban tároljuk $-80^{\circ} \mathrm{C}$-on .

- pGL2 (6 kBp), üres plazmid, $1 \mathrm{mg} / \mathrm{ml}$ koncentrációjú vizes oldatként, $-20^{\circ} \mathrm{C}$-on fagyasztva.

- $\quad$ pJET (4 kBp), üres plazmid, $1 \mathrm{mg} / \mathrm{ml}$ koncentrációjú vizes oldatként, $-20^{\circ} \mathrm{C}$-on tárolva.

- pcOVA (6,7 kBp), ovalbumin allergént kódoló konstrukt, 1 mg/ml-es koncentrációban, $-20^{\circ} \mathrm{C}$-on tárolva.

\section{$\underline{\text { Agaróz gélelektroforézis (AGE) }}$}

A pDNS különböző formáinak kvantitatív meghatározásához agaróz gélelektroforézist alkalmaztunk. A plazmid DNS-ek kettős szálúak, és leggyakrabban cirkulárisak, leginkább baktériumokban fordulnak elő a természetben, de néha megtalálhatók eukarióta szervezetekben is (pl. a Saccharomyces cerevisiae). Méretük 1-től egészen 1000 kilóbázispárig változhat, egy sejtben megtalálható számuk pedig elérheti akár az ezres nagyságrendet is. A plazmidok több különböző konformációban fordulhatnak elő, amely topoizimerek gélelektroforézis során eltérő fajlagos töltéssürüségük miatt elválaszthatók egymástól, ezek ugyanis különböző sebességgel migrálnak a gélben. A „leglassúbb”, vagyis ami legközelebb lesz a zsebhez a nyílt-cirkuláris forma (oc), amikor az egyik szálon van csak vágás. A következő a relaxált forma, amelynek ép mindkét szála, de nem szuperhelikális formában van (nincs feltekeredve, enzimatikusan relaxált). Következő az elektroforetikus mobilitás szerinti sorban a lineáris forma, melyben a pDNSnek van szabad vége (vagyis nem zárt cirkuláris). Ez akkor jöhet létre például, amikor a pDNS két szála ugyanott vágódik, vagy egymáshoz nagyon közel, ezért felnyílik a gyürü. Negyedik konformáció a szuperhelikális forma, vagyis más néven a kovalensen zárt cirkuláris (ccc-forma) pDNS, ahol zárt láncú a pDNS, nincs szabad vége és szuperhelikális formában (feltekeredve) található. Utolsó, a leggyorsabb (legmesszebbre migráló) forma a denaturált szuperhelikális, amely a denaturálódott régiók miatt kevésbé kompakt. Ennek kialakulását általában bázikus környezet, vagy hőhatás okozza. A pDNS-alapú nanomedicínák esetén a szuperhelikális formát találták a legnagyobb biológiai aktivitású konformációnak. ${ }^{97,98}$ 
A kísérleteket 2 protokoll szerint végeztük:

1. $0.8 \%$-os agaróz gélbe $1 \mu \mathrm{g}$ pDNS-t mértünk, 90 percig, 60 Volton, vagy

2. 1\%-os agaróz gélben 250 ng pDNS-t 999 percig, 22 Volton.

A gélek mindig 500 ppm etídium-bromidot tartalmaztak, a használt puffer pedig 8,3-as pH-jú EDTA tartalmú Tris-acetát (TAE) puffer volt. A géleket minden esetben lefotóztuk automatikus expozíciós beállítással, és az Image J szoftver segítségével denzitometrikus alapon értékeltük a topoizomerek százalékos arányát, ahol indokolt volt.

\section{Gél-retardációs módszer}

A gél-retardációs módszernél a fenti AGE módszert az 1. protokoll szerint használtuk. A gélbe felvitt minden mintában a pDNS mennyisége $1 \mu \mathrm{g}$, ezt a mennyiséget titráltuk PEIm-mel. A teljesen kondenzált részecske a zsebben marad, nem migrál a gélbe.

\section{Nanorészecskék dekomplexálása}

A fent leírt módon elkészített nanorészecskéket a nátrium-dodecil-szulfát (SDS) segítségével szedtük szét (dekomplexáltuk), hogy vizsgálhassuk a benne lévő pDNS állapotát (topoizomereinek arányát). Ehhez a részecskét a pDNS foszfátjához képest számított 1000-szeres moláris feleslegü SDS-oldattal inkubáltuk szobahőmérsékleten 1 órán át folyamatos rázatás mellett, majd agaróz gélen vizsgálva, denzitometrikusan értékelve meghatároztuk a pDNS szuperhelikális formájának mennyiségét (ccc\%) az összeshez képest. A dekomplexált részecskében a pDNS koncentrációja is mérhetővé válik UV-fotometriás módszerrel (ennek a módszernek a fejlesztése nem tárgya a dolgozatban, a DermaVir kibővített specifikációjába azonban bekerült).

\section{UV spektrofotometria}

Az UV-méréseket $30 \mu \mathrm{g} / \mathrm{ml}$ pDNS-t tartalmazó oldatból végeztük. A mérésekhez kvarc küvettákat és két utas Jasco spektrofotométert használtunk. Bár leggyakrabban csak a 260 nm-en mért abszorbancia fontos, mivel ez a pDNS abszorbancia-maximuma, az UV- 
méréseknél mindig a teljes spektrumot rögzítettük, 190-1100 nm között, 5 nm-es léptékkel. A nanorészecskéknél megfigyelt hiperkromofória számítása a következő képlet alapján történt:

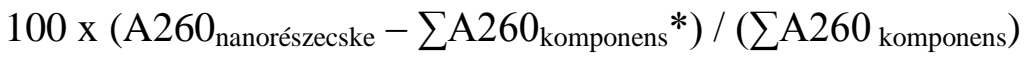

$* \sum \mathrm{A} 260_{\text {komponens }}=\mathrm{A} 260_{\mathrm{pDNS}}+\mathrm{A} 260_{\mathrm{PEIm}}+\mathrm{A} 260_{\text {formulációs oldószer }}$.

Tehát a nanorészecske 260 nm-en mért abszorbanciájának a komponensek 260 nm-en mért abszorbancia-összegéhez viszonyított növekedése százalékos formában.

\section{Részecskeméret mérés}

Részecskeméret méréseket Brookhaven ZetaPALSTM készülékkel végeztük, amely a dinamikus fényszórás (DLS) elvét alkalmazva a részecskék hidrodinamikai átmérőjét (vagyis a hidrátburkot is beleszámolva) határozza meg a Stokes-Einstein egyenlet alapján. A méréseket az (UV mintákat tovább hígítva) 10 $\mu \mathrm{g} / \mathrm{ml}$ pDNS koncentrációjú oldatokból végeztük szobahömérsékleten. A mérés paraméterei: 5 run, hullámhossz: $659 \mathrm{~nm}$, szög:

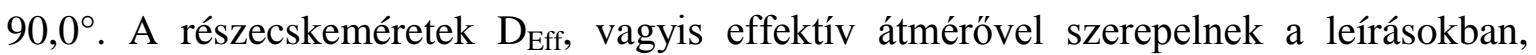
nanométerben $(\mathrm{nm})$.

\section{Zeta potenciál mérés}

Zeta potenciál méréseket szintén a Brookhaven ZetaPALSTM készülékkel végeztük, és ugyanazokat a mintákat használtuk, mint a részecskeméret meghatározásához. Modellnek a Smoluchowski egyenletet választottuk. Beállított paraméterek: dielektromos állandó 78,54, a feszültség 4,0 Volt, a frekvencia 2,0 Hz. A zeta potenciál analíziseknél 5 mérés történt mintánként.

\section{$\underline{\text { Atomerő mikroszkópia (AFM) }}$}

Az AFM felvételek készítésénél $7 \mu$ poliplex szuszpenziót mértünk friss mica lemezre, majd 3 perces inkubáció után ultra tiszta vízzel lemostuk és argon áramban megszárítottuk. A felvételek letapogató (tapping) üzemmódban készültek. Szilikon rugókat 
használtunk, melyek erőállandója $42 \mathrm{~N} / \mathrm{m}$, rezonancia frekvenciája pedig $300 \mathrm{kHz}$, a fej sugara $7 \mathrm{~nm}$. A felvételeket a Nanoscope Imaging és az Image J szoftverek segítségével készítettük és értékeltük.

\section{Induktív csatolású plazma - tömegspektrometria (ICP-MS)}

Az ICP-MS a tömeg spektrometria egy olyan fajtája, amely képes bizonyos fémek és nem fémek akár ppt $\left(10^{-12}\right)$ nagyságrendủ kimutatására és meghatározására. Alapja, hogy az ionizációra szolgáló induktív csatolású plazma módszert egy az ionok elválasztására és detektálására alkalmas tömeg spektrométerrel kötnek össze. Az atomabszorpciós módszerekkel ellentétben így a nyomokban jelenlévő elemeket is gyorsan, pontosan és magas érzékenységgel ki lehet mutatni.

Az ICP-MS méréseket az EPA 6020 európai szabványnak megfelelöen 0,5 ml-es mintákból végeztettük, 3 párhuzamost használva.

\section{$\underline{\text { Total organikus karbon (TOC) }}$}

A TOC mérésekhez a mintákat savval kezelik, $\mathrm{CO}_{2}$-dá alakítják, majd a szervetlen széntartalmat eltávolítják a rendszerből és a visszamaradt organikus karbon mennyiségét a TOC készülékkel megállapítják. A TOC mérésekhez kálium-hidrogén-ftalát standardokkal készítik a kalibrációs sort.

A TOC méréseket az MSZ EN 1484:1998 nemzetközi szabványnak megfelelően 0,5 ml-es mintákból végeztettuik, 3 párhuzamost használva.

\section{Adszorbeálható összes szerves halogén (AOX)}

AOX módszerrel az adszorbeálható szerves halogén-tartalmat lehet meghatározni. Mindazokat a halogén-tartalmú anyagokat meghatározhatjuk ezzel a módszerrel, melyek aktív szénen adszorbeálhatók. Az AOX módszert leginkább felszíni vizek és szennyvizek halogéntartalmának meghatározására használják. A módszer elve a következő: Aktív szenet adunk a vízmintához, majd miután adszorbeálódtak a vízben oldódó szerves molekulák, az aktív szenet kiszürjük, a szervetlen klorid-ionokat eluáljuk enyhén savas 
káliumnitrát-oldattal, végül elégetjük az aktív szenet oxigénáramban. A keletkező halogénsavakat abszorbeáljuk, majd argentometriásan, pl. kulometriával titráljuk. ${ }^{99}$

A méréseket az MSZ EN ISO 9562:2005 nemzetközi szabványnak megfelelően 0,5 ml-es mintákból végeztettük, 3 párhuzamost használva.

\section{pH-potenciometriás titrálás}

A PEIm protonáltságát a $\mathrm{pH}$ függvényében $\mathrm{pH}$-potenciometrikus titrálással vizsgáltuk. A titrálás során 1,25 mM PEIm oldatból kiindulva kezdtük növelni a pH-t nátrium-hidroxid oldat adagolásával. Az ionerősséget 0,1 M-ra állítottuk nátriumkloriddal. Minden titrálást termosztált körülmények között $\left(25 \pm 0,1^{\circ} \mathrm{C}\right)$ végeztünk, argon atmoszférában, számítógép-vezérelt automata bürettával, és pH-mérővel. A PEIm protonálódási együtthatóját 4 párhuzamos titrálásból becsültük PSEQUAD program segítségével. $^{100}$ Minden titrálás 70-80 adatpontból állt. A görbe normálása a következőképpen történt: az erős savra fogyott lúg mennyiségét kivontuk az összes fogyott mennyiségből, majd a PEIm nitrogén koncentrációjához viszonyítva megadtuk a lúgfogyást. A PEIm pK-ja 8,32 — 0,0022-nek adódott, ami egy közelítő egyetemes érték. Valójában a PEIm-nek annyi pK értéke van, ahány $\mathrm{N}$ van a polimer láncban, de mivel azok nagyon közel vannak egymáshoz fellép az úgynevezett polimer effektus, ami nagy eltéréseket okoz a szokásos szekunder aminokra mérhető pK-hoz képest már rövid lánchosszú polietilénimineknél is (pl. 5 monomer egység). ${ }^{101,102}$ Ezért a legcélszerübb volt az átlagos, becsült pK értéket használni.

\section{Nukleáz enzimmel szembeni ellenállás}

A nanorészecskét az aspecifikus endonukleázzal (DNase I) inkubáltuk a gyártó előírásai szerint, majd EDTA-val leállítottuk a reakciót, dekomplexáltuk a részecskét és agaróz gélen vizsgáltuk a detektálható pDNS mennyiségét. 


\section{Biológiai aktivitás mérés}

A formulációk biológiai aktivitását in vitro rendszeren teszteltük. A teszt lényege, hogy a kész nanorészecske-szuszpenziót lemezre kiültetett sejtekre pipettázzuk, majd 21 óra inkubáció után leszívjuk a felülúszót és abban az expresszált fehérjéket kvantifikáljuk HIV-1 ELISA (enzyme-linked immunosorbent assay) segítségével, így számszerüsítve az adott formuláció biológiai aktivitását. A folyamat részletesen:

A kísérletekben használt 293T sejtvonal (humán embrionális vesesejt) széles körben használt hasonló analitikai célokra ${ }^{103}$. A sejtek kiolvasztás, sejt-indítás és passzálások után kerülnek 48- vagy 96 lyukú lemezre. Minden lyukba 200000 sejt kerül a 48 lyukú lemeznél és 30000 a 96 lyukúnál. 24 órával a lemezre való kiültetés után transzfektáljuk őket, vagyis rájuk pipettázzuk a nanorészecske-szuszpenziót. 21 órás inkubáció után leszívjuk a felülúszót, amelyből szelektíven meghatározzuk HIV-1 ELISA kit (Zeptometrix) segítségével a pDNS-ben kódolt fehérjék közül a p24 nevü kapszid fehérje expresszálódott mennyiségét. Mivel ez egy késői fehérje, vagyis csak akkor kezd átíródni, mikor a többi már expresszálódott, alkalmas arra, hogy egyedül is mértéke legyen az in vitro biológiai aktivitásnak. ${ }^{77}$ Az ELISA elve és folyamata dióhéjban a következő:

A kitben található 96 lyukú lemez lyukai p24 fehérjére specifikus monoklonális antitesttel vannak bevonva. Miközben a sejtekről leszívott felülúszót inkubáljuk a lemezen, az abban található p24 fehérjemolekulák hozzákötődnek az immobilizált antitesthez. Ezután a kötött antigén reagál a reagens, humán anti-HIV-1 biotinnal konjugált másodlagos antitesttel (szendvics ELISA). Következő lépésben sztreptavidin-peroxidázt mérünk a lemezre, majd a szubsztrátot, amely hatására kék színü termék keletkezik az enzimreakcióban, amit egy kénsavat tartalmazó stop-oldat hozzáadása sárgává változtat. A szubsztráttal keletkezett termék mennyisége arányos a $450 \mathrm{~nm}$-en mért abszorbanciával és a kiindulási sejtfelülúszó p24 fehérje-tartalmával. A kit standardjainak kalibrációs sorából a pontos fehérjekoncentráció kiszámítható.

A biológiai aktivitás vizsgálat minden lépése szigorúan standardizált mủveleti elöírás szerint zajlik, a módszer a nemzetközi gyógyszer-engedélyeztető hatóságok elvárásai alapján validált. Bizonyított linearitásának köszönhetően alkalmas arra, hogy a különböző formulációk közötti különbséget kvantitatívan kimutassa. 
A biológiai aktivitás vizsgálat eredményeinek könnyebb értelmezéséhez legtöbb esetben az adatok relatív, százalékos formában szerepelnek valamely belső standard, vagy viszonyítási alaphoz képest (ez az adott helyen fel van tüntetve).

* A nanomedicína hivatalos referencia standardja a jelenlegi klinikai formuláció. 


\section{EREDMÉNYEK ÉS ÉRTÉKELÉSÜK}

\subsection{A DermaVir nanomedicína formuláció fejlesztése}

\subsubsection{A jelenlegi klinikai formuláció problémái}

Az jelenlegi klinikai formuláció számos problémás tulajdonsággal rendelkezik. Az egyik legkritikusabb, hogy a pDNS és a PEIm mellett a formulációs oldószer 10\%-os gyógyászati glükóz/dextróz oldat, ami a készítmény instabilitásának egyik fő oka. Ennek magyarázata, hogy a reduktív glükóz molekula a PEIm aminjaival Maillard-típusú reakcióban sárga mellékterméket képez, ami az oldatok összekeverése után pár órával már szemmel láthatóan sárgává színezi az oldatot (3. Ábra). ${ }^{104,105}$

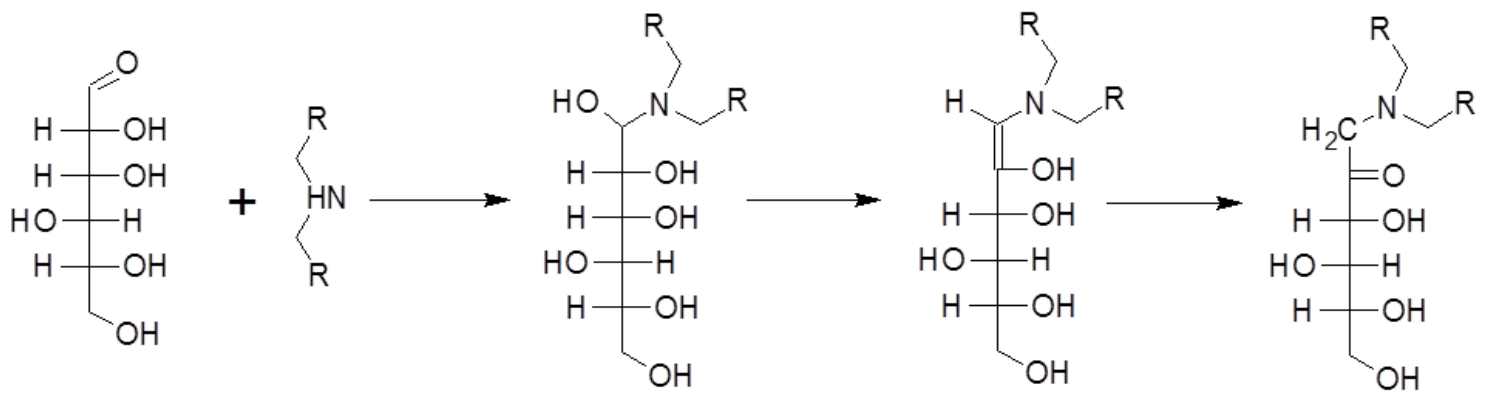

3. Ábra. A glükóz és PEI közötti Maillard-típusú reakció, melynek mellékterméke sárga színü (UV-vis spektrofotometriával kimutatható).

Mivel egy ilyen mellékreakció játszódik le a komponensek között, a DermaVir ebben a formulációban nem tartható el pár óránál tovább az összekeverés után, ezért készítik a klinikán mindig frissen a kezelés előtt és használják fel 3 órán belül.

A másik probléma az eredeti formulációval, hogy bár annak komponenseit, a Helyes Gyógyszergyártási Gyakorlat (GMP) elöírásainak megfelelően gyártották kielégítve a gyógyszer-engedélyeztető hatóságok követelményeit, mégis meglehetősen alulkarakterizáltak, kémiai környezetük és ionos karakterük nem definiált. A kész nanomedicína termék specifikációja is csupán a fizikai megjelenés, az azonosság, a tartalom és a biológiai aktivitásra tér ki (1. Táblázat). Ez a specifikáció tökéletesen 
megfelel a klinikai II-es fázis stádiumánál elvárt körülményeknek, a termék további vizsgálata, és fejlesztésének elörehaladása során azonban a hatóságok elvárják, hogy a termék minőségi előirata is vele „fejlődjön”.

1. Táblázat. DermaVir nanomedicína kezdeti specifikációja.

\begin{tabular}{lcc}
\hline \multicolumn{1}{c}{ Paraméter } & Módszer & Elfogadási kritérium \\
\hline Megjelenés & Szemrevételezés & Tiszta, színtelen oldat \\
Azonosság & Agaróz gélelektroforézis & Nincs migráció \\
Tartalom & UV-spektrofotometria & $0,24-0,35$ \\
Biológiai aktivitás & Transzfekciós módszer & p24 > $12 \mathrm{ng} / \mathrm{ml}$ \\
\hline
\end{tabular}




\subsubsection{A PEIm komponens optimalizálása}

A polimer ionos jellege

A PEIm eredeti specifikációjában, a kationos jellegre utalóan semmilyen információ nem volt található (2. Táblázat), annak ellenére, hogy a polimer a DermaVir rendszer polikationja, így a formuláció szempontjából ez fontosabb tulajdonsága.

2. Táblázat. A PEIm eredeti specifikációja.

\begin{tabular}{|c|c|c|}
\hline Paraméter & Módszer & Elfogadási kritérium \\
\hline Megjelenés & Szemrevételezés & Tiszta oldat \\
\hline Azonosság & Rezorcinol-kénsavas módszer & $2-4 \%$ mannobióz \\
\hline \multirow{2}{*}{ Tartalom } & $\begin{array}{l}\text { Gélpermeációs kromatográfia } \\
\text { (Sephadex PD10 oszlop) }\end{array}$ & $\begin{array}{c}\text { A kromatorgamon egy csúcs jelenik meg } \\
\text { (PEIm), nincs másodlagos csúcs (szabad } \\
\text { mannobióz) }\end{array}$ \\
\hline & $\begin{array}{l}\text { Agaróz gélelektroforézis } \\
\text { (retardációs módszer) }\end{array}$ & $\begin{array}{l}\text { A teljes kondenzációhoz szükséges N/P } \\
\text { arány 1,5-2,5 között }\end{array}$ \\
\hline Biológiai aktivitás & Transzfekciós módszer* & Eredmény jelentése \\
\hline $\begin{array}{l}\text { Mikrobiológiai } \\
\text { minőség }\end{array}$ & Ph.Eur. 2.6.12 és 2.6.13 & Ph.Eur. 5.1.4, 2-es kategória \\
\hline Endotoxin & LAL teszt & $<0,1 \mathrm{U} . \mathrm{E} / \mathrm{mL}$ \\
\hline
\end{tabular}

Amikor a klinikán használt PEIm (PEIm-1) után egy következő, újabb lot polimer (PEIm-2) érkezett, azt találtuk, hogy azonos formulációban készítve (ugyanazzal a pDNSsel és formulációs oldószerrel), az újabb PEIm-mel készült nanorészecskék biológiai aktivitása szignifikánsan magasabb (4. Ábra). 


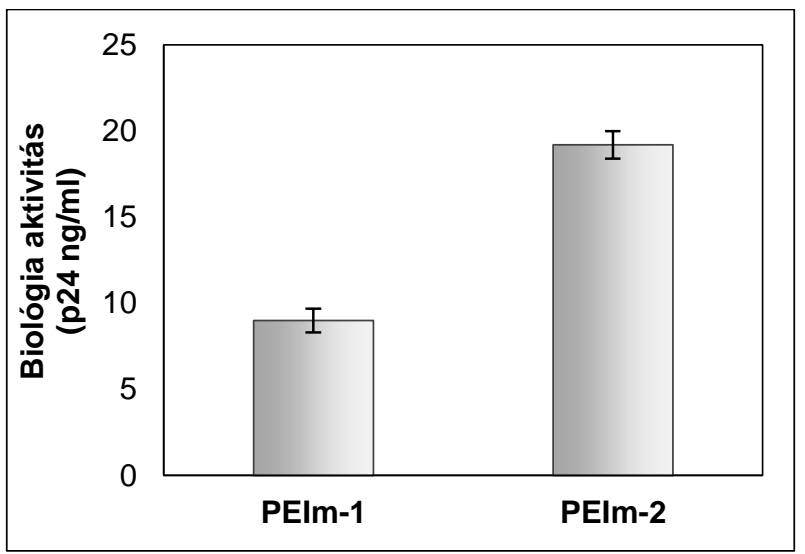

4. Ábra. Különbözö lot PEIm-böl készített nanorészecskék biológiai aktivitása (azonos pDNS és formulációs oldószer mellett): PEIm-1 a klinikai anyag, PEIm-2 az újabb lot polimer.

Mivel a specifikációban megadott tulajdonságokban mind megegyezik a két lot polimer, részletes elemanalízis vizsgálatnak vetettük alá őket, hogy megtaláljuk a különbséget. Ennek eredményét a 3. Táblázat mutatja.

3. Táblázat. A két különböző lot PEIm elemanalízis vizsgálatának eredménye.

\begin{tabular}{|c|c|c|c|c|c|c|}
\hline Lot & $\mathbf{C}^{*}$ & $\mathbf{N}^{* * *}$ & $\mathbf{P}$ & $\begin{array}{l}\mathrm{Na} \\
\%)\end{array}$ & $\mathbf{M g}$ & $\mathrm{Cl}^{* * * *}$ \\
\hline PEIm-1 & 387 & 191 & 22 & 10 & 3 & 436 \\
\hline PEIm-2 & 389 & 192 & 41 & 7 & 2 & 193 \\
\hline
\end{tabular}

A TOC, illetve az AOX mérések eredményéböl kiderült, hogy a klór-nitrogén $\left(\mathrm{Cl}^{-} / \mathrm{N}\right)$ arány a klinikán is használt PEIm-nél (PEIm-1) 0,9, míg az újnál (PEIm-2) 0,6. A klinikai PEIm protonáltsági foka tehát $90 \%$, ez azt jelenti, hogy a nitrogének $90 \%$-a hidroklorid-só 
formájában van az oldatban, vagyis $-\mathrm{NH}_{2}{ }^{+} \mathrm{Cl}^{-}$formában. $\mathrm{Az}$ új lot PEIm (PEIm-2) protonáltsági foka ezzel szemben csak 60\%-nak adódott. Kiderült tehát, hogy a két lot PEIm protonáltsági foka - a kationos jelleg az a tulajdonság, melyben eltérnek. Annak kiderítéséért, hogy valóban az ionos jelleg mértéke-e az a tulajdonság, ami az eltérő biológiai aktivitást okozza, a következő kísérletet végeztük: az eredeti 0,9 -es $\mathrm{Cl}^{-} / \mathrm{N}$ arányú PEIm protonáltsági fokát nátriumhidroxid oldat segítségével beállítottuk 0,$3 ; 0,4 ; 0,5 ; 0,6$; 0,7 és 0,8-ra, majd az ezekből készített nanorészecskéket vizsgáltuk (5. Ábra).

A

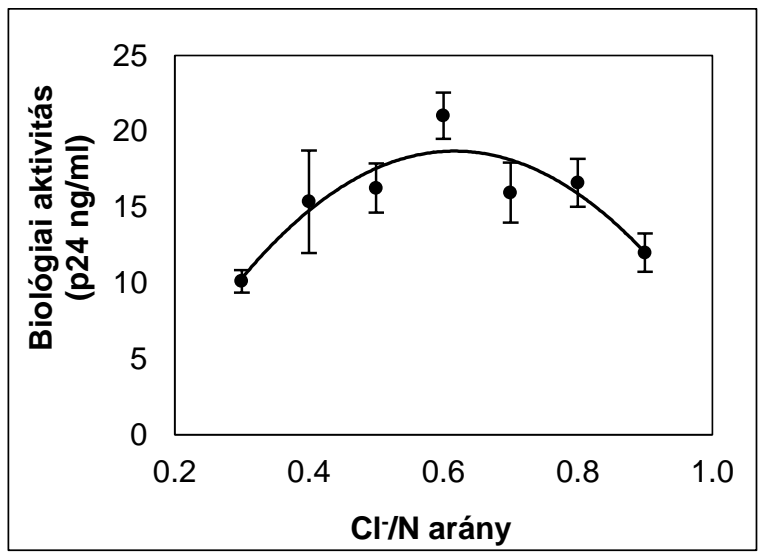

B

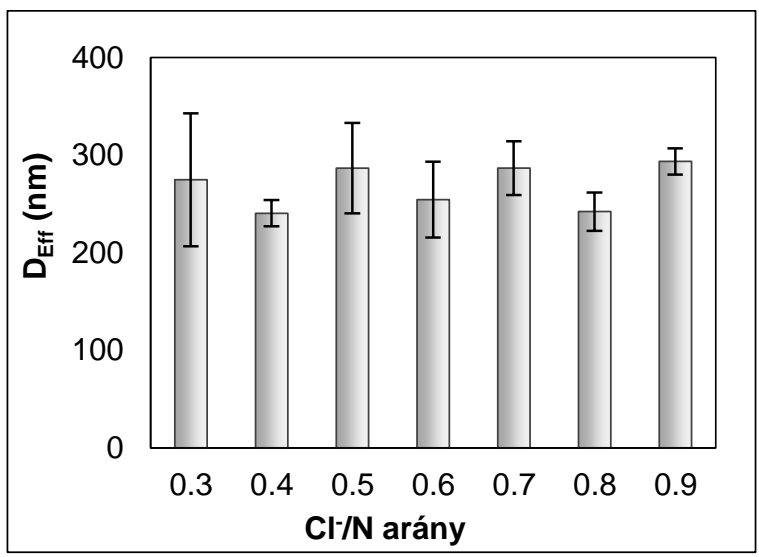

5. Ábra. Különbözö $\mathrm{Cl}^{-} / \mathrm{N}$ arányú PEIm-eket tartalmazó formulációk vizsgálata. A) In vitro biológiai aktivitás eredmények $\left(\mathrm{y}=-83,6 \mathrm{x}^{2}+103,1 \mathrm{x}-13,1, \mathrm{R}^{2}=0,83\right)$. B) Effektív átmérö eredmények.

A formulációkban az oldószer és a pDNS minden mintában ugyanaz volt. Az eredmény azt mutatja, hogy a biológiai aktivitás másodfokú polinóm szerint változik (5. Ábra, A), és maximuma 0,61-nél van. A biológiai aktivitással ellentétben a részecskeméretet nem befolyásolta a $\mathrm{Cl}^{-} / \mathrm{N}$ arány változtatása (5. Ábra, B).

\section{A polimer molekulatömege}

Megvizsgáltuk, hogy a PEIm molekulatömege milyen befolyással van a részecske tulajdonságaira, ha ugyanazt a pDNS-t és formulációs oldószert használjuk, illetve a nitrogén koncentrációt rögzítjük (vagyis minden molekulahossz esetében a monomerek 
száma megegyezik). Az eredményeket a 4. Táblázat foglalja össze. A polimer azonos cukortartalma mellett (3 mól\%) a kialakuló nanorészecskék mérete a vizsgált tartományban nem korrelál a PEIm molekula hosszával, a biológiai aktivitás pedig a három vizsgált molekulatömegü polimer közül a klinikán használatos, 32800 Da-osnál a legmagasabb: mind a kisebb, 9000-es, mind a nagyobb 50000-es PEIm kisebb potenciát mutatott.

4. Táblázat. A különböző molekulatömegü PEIm-ek ugyanazzal a pDNS-sel alkotott nanorészecskéinek effektív átméröi és relatív biológiai aktivitása a kontroll, 32800 Da-oshoz (klinikai anyag) viszonyítva.

\begin{tabular}{cccc}
\hline $\begin{array}{c}\text { PEIm móltömege } \\
(\mathbf{M n}, \mathbf{D a})\end{array}$ & $\begin{array}{c}\text { PEIm mannobióz } \\
\text { tartalma }(\%)\end{array}$ & $\begin{array}{c}\mathbf{D}_{\text {Eff }} \pm \mathbf{S D} \\
(\mathbf{n m})\end{array}$ & $\begin{array}{c}\text { Biológiai aktivitás } \\
(\mathbf{p 2 4 \%})\end{array}$ \\
\hline 8600 & 3 & $225 \pm 21$ & $41 \pm 12$ \\
32800 & 3 & $172 \pm 43$ & $100 \pm 10$ \\
50500 & 3 & $189 \pm 7$ & $80 \pm 8$ \\
\hline
\end{tabular}

$\underline{\text { A polimer cukortartalma }}$

Mivel a részecske patogén-szerü kinézetéhez fontos a polimerhez kötött mannobióz, illetve a célozni kívánt Langerhans-sejteknek van mannóz receptora, a molekulahosszhoz hasonlóan azt is megvizsgáltuk, hogyan változnak a fenti tulajdonságok, ha a polimer cukortartalmát változtatjuk. Ugyanarra a PEI-re különböző mennyiségben kapcsoltunk mannobiózt, majd megvizsgáltuk az ugyanazzal a pDNS-sel és pufferrel alkotott nanorészecske méretét és biológiai aktivitását (5. Táblázat).

A cukortartalom és a részecskeméret között ismét nem találtunk összefüggést a vizsgált tartományban, azonban biológiai aktivitásban az eredmény szerint szükség van a mannobiózra; a 0,1\% nem elegendő ahhoz, hogy hatékony formuláció jöjjön létre, de a 3\% és a $10 \%$ között szignifikáns különbség nincs, vagyis a még magasabb cukortartalom nem jár együtt megnövekedett biológiai aktivitással. 
5. Táblázat. A különböző cukortartalmú PEIm-ek ugyanazzal a pDNS-sel alkotott nanorészecskéinek effektív átmérői és relatív biológiai aktivitása a kontroll, 3\%-oshoz (klinikai anyag) viszonyítva.

\begin{tabular}{cccc}
\hline $\begin{array}{c}\text { PEI móltömege } \\
(\mathbf{M n}, \mathbf{k D a})\end{array}$ & $\begin{array}{c}\text { PEIm mannobióz } \\
\text { tartalma }(\%)\end{array}$ & $\begin{array}{c}\mathbf{D}_{\text {Eff }} \pm \text { SD } \\
(\mathbf{n m})\end{array}$ & $\begin{array}{c}\text { Biológiai aktivitás } \\
(\mathbf{p 2 4 \%})\end{array}$ \\
\hline 22 & 0,1 & $264 \pm 46$ & $3 \pm 1$ \\
22 & 3 & $172 \pm 43$ & $100 \pm 10$ \\
22 & 10 & $295 \pm 21$ & $109 \pm 5$ \\
\hline
\end{tabular}

A fenti kísérlet-sorozatból arra a következtetésre jutottunk, hogy a PEIm a molekulatömegétől függetlenül képes kondenzálni a pDNS-t, és az így létrejött részecskék biológiai aktivitása a vizsgált tartományban nem korrelál a molekula hosszával, ahogy a létrejövő poliplex mérete sem. Igazoltuk azt is, hogy a PEIm/pDNS nanorészecske hatékonyságához szükség van a PEIm láncra kapcsolt cukorszerü molekulára, de annak mennyiségét 3\%-on túl növelve nem kapunk magasabb biológiai aktivitást.

Miután megállapítottuk, hogy a PEIm polikation 60\%-os protonáltsági foka az ideális, valamint hogy az eddig használt molekulatömeg és mannobióz-tartalom optimális, kibővítettük a polimer specifikációját a 6 . Táblázatban feltüntetett paraméterekkel, majd a formuláció fejlesztését a pDNS komponens górcső alá vételével folytattuk.

6. Táblázat. A PEIm specifikációjába bekerült vizsgálati paraméterek (a szervetlen szennyezők a pDNS alábbi vizsgálata miatt kerültek be).

\begin{tabular}{lcc}
\hline \multicolumn{1}{c}{ Paraméter } & Módszer & Elfogadási kritérium \\
\hline Klórtartalom & AOX & $33,9-24,5 \pm 1,5 \mathrm{~m} / \mathrm{m} \%$ \\
$\begin{array}{l}\text { Szervetlen szennyezők } \\
\text { (Na, fémek) }\end{array}$ & ICP-MS & $<100 \mathrm{ppm}$ \\
\hline
\end{tabular}




\subsubsection{A plazmid DNS komponens optimalizálása}

\section{A pDNS oldat ionerössége}

A pDNS-t, az aktív hatóanyagot, a szerződéses gyártók a Helyes Gyógyszergyártási Gyakorlat szigorú követelményei szerint gyártották. Ennek ellenére, két különböző gyártótól származó ugyanazon pLWXu1 konstrukt tulajdonságai között nagy különbségeket találtunk. Mindkettőt $1 \mathrm{mg} / \mathrm{ml}$-es steril oldatként, ioncserélt vízben, $-80^{\circ} \mathrm{C}$ on tároltuk. Azonban amikor mindkettőt a DermaVir formulációban vizsgáltuk, azt tapasztaltuk, hogy a biológiai aktivitás (6. Ábra) között szignifikáns a különbség.

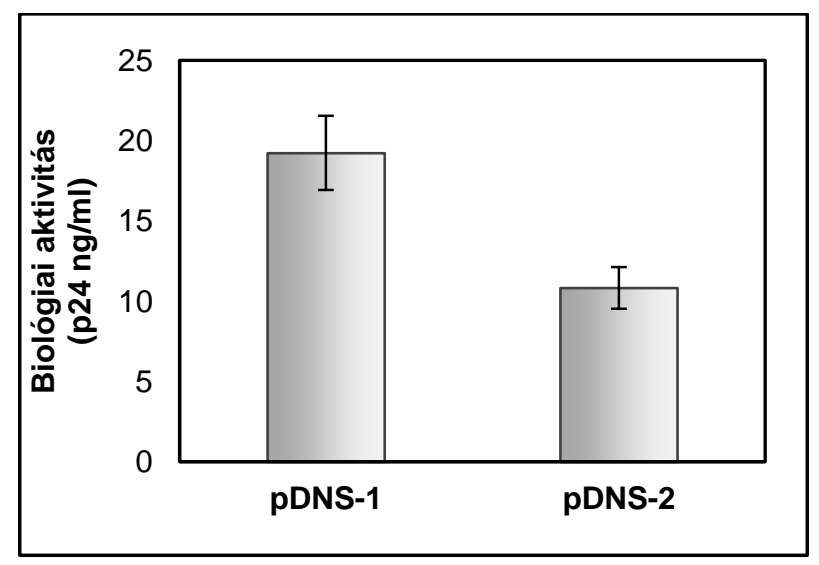

6. Ábra. A két különböző gyártó által gyártott azonos pDNS konstruktokból készített részecskék biológiai aktivitás vizsgálata $(\mathrm{p}<0,0001)$.

A használt PEIm és a formulációs oldószer mindkét vizsgált poliplexnél a klinikán is használatos anyagok voltak (90\%-os protonáltsági fokú PEIm és $10 \%$ glükóz/dextróz oldat). A PEIm fenti esetéhez hasonlóan mind a két pDNS megfelelt az akkori specifikációnak: vagyis a homogenitás (szuperhelikális forma mennyisége), a tisztaság (RNS, fehérje és genomiális DNS szennyezők mennyisége, bakteriális endotoxin), illetve az identitás (vagyis a szekvencia-azonosság) szempontjából azonosak voltak (7. Táblázat). 
7. Táblázat. A pLWXu1 plazmid DNS specifikációja.

\begin{tabular}{|c|c|c|}
\hline Paraméter & Módszer & Elfogadási kritérium \\
\hline Megjelenés & Szemrevételezés & Tiszta, színtelen oldat \\
\hline Koncentráció & UV-spektrofotometria $260 \mathrm{~nm}$-en & $1,0-1,2 \mathrm{mg} / \mathrm{ml}$ \\
\hline Szekvencia-azonosság & $\begin{array}{l}\text { RFLP (restrikciós fragmenthossz- } \\
\text { polimorfizmus) analízis NotI, BamHI } \\
\text { enzimekkel }\end{array}$ & $\begin{array}{l}\text { Minden várható fragmens } \\
\text { megjelenése: } \\
\text { NotI: } 12252 \mathrm{bp}\end{array}$ \\
\hline \multirow{2}{*}{$\begin{array}{l}\text { Szuperhelikális forma } \\
\text { mennyisége }\end{array}$} & Etídium-bromid gélelektroforézis & Domináns a gélen \\
\hline & HPLC & $>80 \%$ \\
\hline \multirow{2}{*}{ Maradvány RNS } & Etídium-bromid gélelektroforézis & $\begin{array}{c}\text { Nem detektálható } 0,5 \mu \mathrm{l}-\mathrm{t} \text { a } \\
\text { zsebbe betöltve }\end{array}$ \\
\hline & HPLC & $<5 \%$ \\
\hline $\begin{array}{l}\text { Bakteriosztázis és } \\
\text { Fungisztázis }\end{array}$ & USP $28<71>$ & Növekedést nem gátolja \\
\hline \multirow{2}{*}{ Maradvány protein } & UV-spektrofotometria & A260/A280 arány 1,7-2,0 között \\
\hline & BCA-módszer & $<1 \%$ \\
\hline Maradvány E.coli DNS & Q-PCR & $<3 \%$ \\
\hline $\begin{array}{l}\text { Maradvány izopropanol és } \\
\text { Etanol }\end{array}$ & USP <467> & $\begin{array}{l}<5000 \mathrm{ppm} \\
<5000 \mathrm{ppm}\end{array}$ \\
\hline $\begin{array}{l}\text { Maradvány antibiotikum } \\
\text { (kanamicin-szulfát) }\end{array}$ & $\mathrm{USP}<81>$ & $\begin{array}{l}\text { Nem detektálható } \\
\text { (határ: } 8 \mu \mathrm{g} / \mathrm{ml} \text { ) }\end{array}$ \\
\hline Endotoxin (LAL) & USP $<85>$ & $<5 \mathrm{EU} / \mathrm{mg}$ \\
\hline Sterilitás & USP23 <71> & Nincs növekedés \\
\hline pH & pH-metria & $6-8$ \\
\hline Biológiai aktivitás & Transzfekciós módszer & $\mathrm{p} 24>12 \mathrm{ng} / \mathrm{ml}$ \\
\hline
\end{tabular}

Hogy az eltérő potenciára magyarázatot találjunk, a két pDNS oldatot ismételten részletes elemanalízis vizsgálattal hasonlítottuk össze. Ennek eredményét a 8. Táblázat foglalja 
össze. A pDNS-1 a jelenlegi klinikai formulációban használt pLWXu1 konstrukt, míg a pDNS-2 ugyanez a plazmid, másik gyártótól. Szembetűnő különbség csupán az ionerősségben van, a pDNS-1-es mellett körülbelül 6 molekvivalens nátrium van jelen, a klór-mennyiség alapján ez föként nátrium-klorid formában, míg a pDNS-2 mellett csak kb. 0,3 molekvivalens nátrium-klorid található (molekvivalens: pDNS foszfátra vonatkoztatott relatív anyagmennyiség).

8. Táblázat. A két különböző lot pDNS elemanalízis vizsgálatának eredménye.

\begin{tabular}{cccccc}
\hline Lot & $\mathbf{C}^{*}$ & $\mathbf{P}$ & $\mathbf{N a}$ & $\mathbf{M g}$ & $\mathbf{C l}^{* * *}$ \\
& & & $\mathbf{m g} / \mathbf{L}(\mathbf{\pm 1 0 \%})$ & & \\
\hline pDNS-1 & 405 & 100 & 403 & 32 & 521 \\
pDNS-2 & 390 & 93 & 25 & 1 & 3 \\
\hline $\begin{array}{l}\text { *TOC-vel mérve. } \\
\text { **AOX-szel mérve. }\end{array}$ & & & & & \\
\end{tabular}

Annak kiderítésére, hogy ez az egyetlen kimutatható különbség okozza-e a biológiai aktivitásbeli eltérést, a következő kísérleti tervet dolgoztuk ki: a pDNS-2 kis adagjait kiegészítettük 3-, illetve 6 molekvivalensnyi nátriumra NaCl-oldat hozzáadásával, mielőtt DermaVirt készítettünk belöle. A harmadik vizsgált pontnak a pDNS-2-t magát, vagyis a 0,3 molekvivalensnyi NaCl-ot tartalmazó pDNS oldatot használtuk. Megmértük az in vitro biológiai aktivitásokat, és arra az eredményre jutottunk, hogy a $\mathrm{NaCl}$ mennyiségének növelése növeli a biológiai aktivitást, amennyiben ugyanazt a PEIm-et és formulációs oldószert használjuk, rögzített pH-n (7. Ábra). Amikor a pDNS-2 NaCltartalma elérte a pDNS-1-ben található 6 molekvivalenst, a belőle készült nanorészecske is utolérte a pDNS-1 poliplexének biológiai aktivitását (7. Ábra, A). A részecskeméretek ezzel szemben állandónak tekinthetők mindhárom formulációnál (7. Ábra, B). Ez az eredmény azt sugallja, hogy a pDNS oldat ionerőssége, különösen a nátrium-klorid tartalma, befolyásolja a nanorészecske biológiai aktivitását, így a génexpressziót. 
A

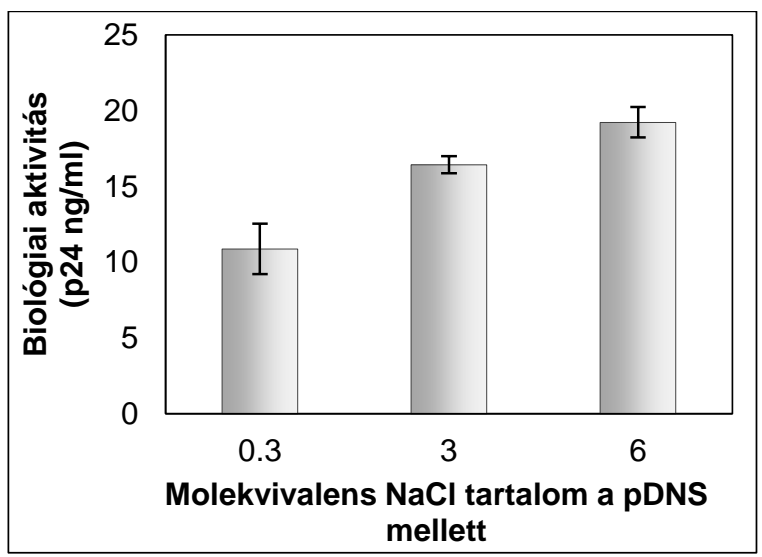

B

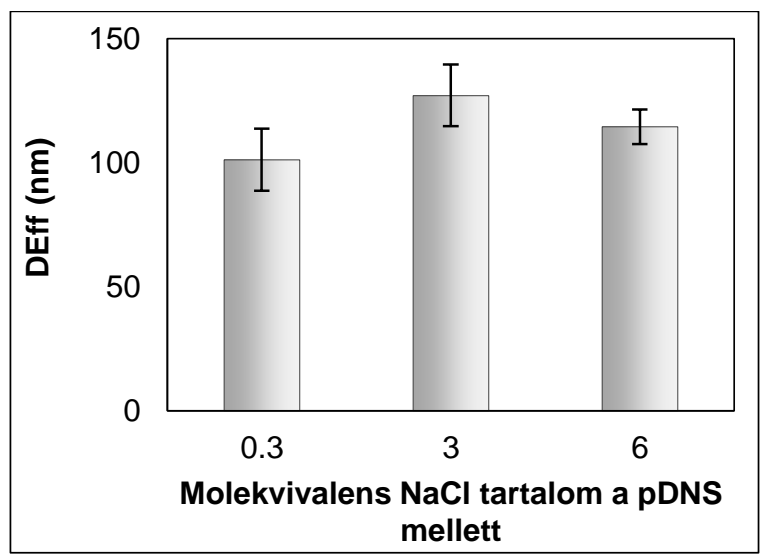

7. Ábra. A pDNS-2-t $(0,3)$ és a 3, illetve 6 molekvivalensnyi NaCl-ot tartalmazó pDNS-2-ből készült formulációk A) biológiai aktivitása és B) effektív átmérői (a pDNS-eken kívül ugyanazt a PEIm-1-et és formulációs oldószert használtuk, ugyanazon a pH-n).

A $\mathrm{NaCl}$ koncentráció kérdését tovább vizsgáltuk, ugyanis az irodalomban is elfogadott tény, hogy a pDNS-t stabilizálja a $\mathrm{NaCl}^{106,107}$ A következő kísérletet terveztük: egy hetes, $37^{\circ} \mathrm{C}$-os tárolásra tettünk le pDNS mintákat, melyek 0,$3 ; 1 ; 3 ; 6 ; 10$ molekvivalens $\mathrm{NaCl}$-ot tartalmaztak, kétféle összetételben; egy sorozat 6 rész formulációs puffert is tartalmazott, míg a második sorozat csak a különböző mennyiségü NaCl-dal kiegészített pDNS oldatokat. Az egy hét lejárta után a tárolt pDNS-ekböl DermaVirt készítettünk, majd a 0,3 molekvivalens NaCl-ot tartalmazó pDNS-2-böl frissen készített DermaVirhez viszonyítva megmértük a biológiai aktivitásokat. Az eredményt a 8. Ábra mutatja. A NaCl önmagában nem volt képes megvédeni a pDNS-t a degradációtól, a formulációs puffer azonban igen, ahogy az a 0,3 molekvivalens NaCl-ot tartalmazó, pufferben tárolt pDNS-nél látszik. Emellett azt is megfigyelhetjük, hogy a puffer mellett jelen lévő $\mathrm{NaCl}$ nem javítja a stabilitást; az összes, pufferben tárolt minta egyforma biológiai aktivitást mutat a $\mathrm{NaCl}$ mennyiségétöl függetlenül. 


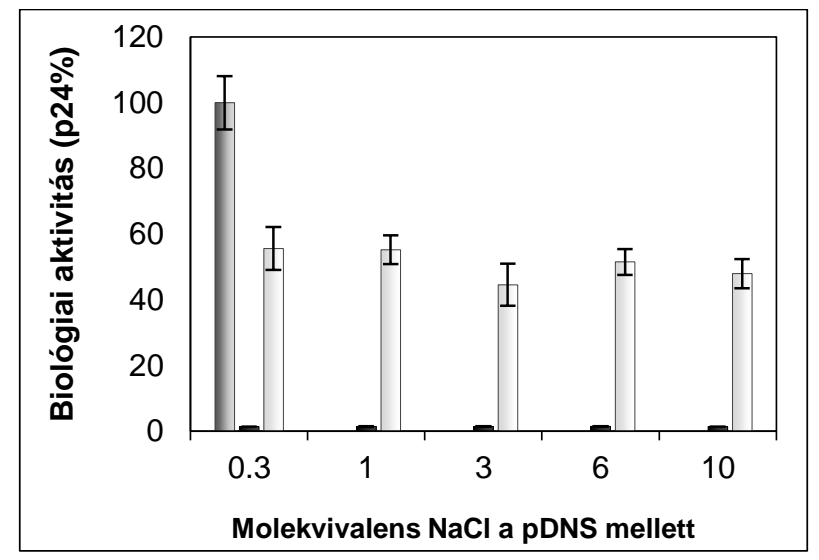

8. Ábra. A NaCl-dal ( $\square)$, illetve a NaCl-dal és formulációs pufferrel ( $\square$ ) tárolt pDNS-ekből ugyanazzal a PEIm-mel készített nanorészecskék biológiai aktivitása a 0,3 molekvivalens NaCl-ot tartalmazó friss kontrollhoz képest (ם).

\section{A szuperhelikális forma aránya}

A pDNS oldat kémiai környezete mellett fontos tulajdonsága a szuperhelikális forma mennyiségének aránya a különböző topoizomerekhez képest. Az irodalomban elfogadott tény, hogy a DNS vakcinák (nem nanorészecskévé formulált készítmények) hatékonyságát a pDNS ccc formájának mennyisége határozza meg; minél magasabb, annál potensebb. ${ }^{60,97,98}$ Ezt a paramétert a nanorészecskénél is meg akartuk vizsgálni, így a következő kísérleti tervet készítettük; hogy minél inkább tükrözzük a természetes degradációból eredő potencia-változást, a különböző ccc\%-ú pDNS-eket nem enzimek segítségével emésztettük, hanem úgy készítettük, hogy a biológiai aktivitás vizsgálat előtt különböző időpontokban tettünk $37^{\circ} \mathrm{C}$-ra mintákat ugyanabból a pDNS-oldatból $(14,13$, 10, 8, 6, 3 és 1 nap). A biológia aktivitás vizsgálat napján agaróz gélelektroforézissel ellenőriztük a különböző időpontokban letett pDNS minták ccc\%-át. Az eredmény azt mutatja, hogy a korreláció másodrendü függvény szerint alakul a ccc\% és a biológiai aktivitás között (9. Ábra). Igazoltuk tehát, hogy a szuperhelikális forma mennyisége alapvetően befolyásolja a biológiai aktivitást a formulált („becsomagolt”) plazmid esetében is. A fenti kísérletben a természetes módon degradálódott pDNS-ek mellett arra is kíváncsiak voltunk, hogy mi történik, ha linearizáljuk a plazmidot. Ehhez kétféleképpen emésztettük: az elsőnél az antibiotikum-rezisztenciáért felelős kanamicin génben vágtuk el 
a plazmidot (Lineáris \#1), vagyis az ,aktív”, HIV géneket nem érinti a vágás. A másodiknál pedig a gag génben, vagyis a HIV kapszid fehérjéjét kódoló részben vágtunk (Lineáris \#2). A biológiai aktivitás vizsgálat ezeknél a mintáknál nem hozott meglepő eredményt, a kanamicinben vágott Lineáris \#1 plazmidnál ki lehetett ugyan mutatni némi aktivitást (3\%), de a gag génben vágottnál (Lineáris \#2) nem volt detektálható mennyiségü expresszált protein (9. Ábra).

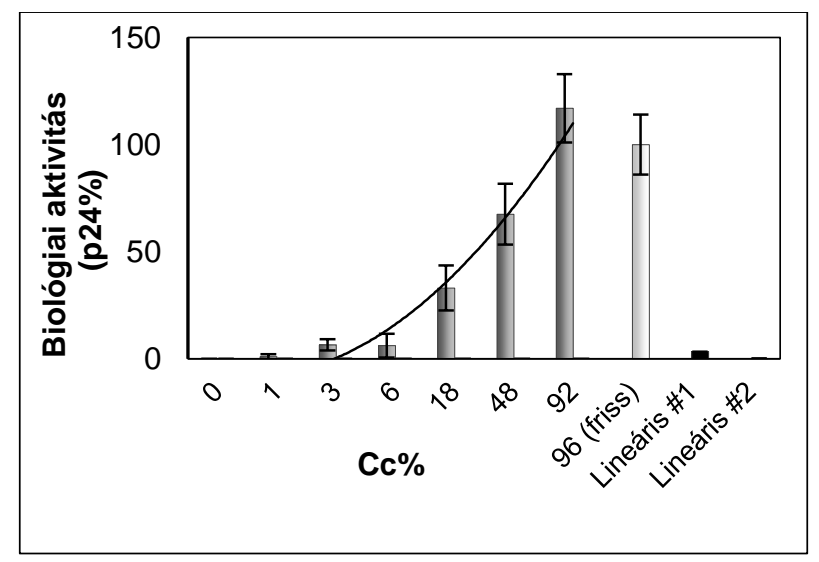

9. Ábra. Különböző ccc\%-ú pDNS-ekből ( $\square$ ) illetve a két fajta lineáris pDNS-ből (ロ) ugyanazzal a PEImmel és pufferrel készített DermaVirek relatív biológiai aktivitása a friss kontrollhoz $(\square)$ képest $(\mathrm{y}=$ $\left.0,0044 x^{2}+1,6702 x+0,1673, r^{2}=0,9963\right)$. Lineáris \#1 - kanamicin génben elvágott lineáris plazmidot tartalmazó nanorészecske, Lineáris \#2 - gag génben elvágott lineáris plazmidot tartalmazó nanorészecske.

A biológiai aktivitás vizsgálat mellett arra is kíváncsiak voltunk, hogy vajon változik-e a részecskeméret, ha különböző ccc\%-ú pDNS-eket „csomagolunk” ugyanabba a polimerbe. A fentihez hasonló módon degradált plazmidokkal készített nanorészecskék részecskeméretét megmérve nem találtunk korrelációt a szuperhelikális forma mennyiségének aránya és a kialakuló poliplex részecskemérete között (9. Táblázat). Függetlenül attól, hogy a pDNS-ben mekkora százalékkal szerepel a szuperhelikális forma, a PEIm körülbelül egyforma effektív átmérőjü nanorészecskékké kondenzálja azt. 
9. Táblázat. A PEIm különböző ccc\%-ú pDNS-ekkel alkotott nanorészecskéinek effektív átmérői.

\begin{tabular}{cc}
$\begin{array}{c}\text { Szuperhelikális pDNS mennyisége } \\
(\%)\end{array}$ & $\begin{array}{c}\mathbf{D}_{\text {Eff }} \pm \mathbf{S D} \\
(\mathbf{n m})\end{array}$ \\
\hline 8 & $145 \pm 8$ \\
17 & $143 \pm 2$ \\
31 & $136 \pm 4$ \\
55 & $148 \pm 4$ \\
75 & $190 \pm 1$ \\
81 & $130 \pm 7$ \\
95 & $130 \pm 5$ \\
\hline
\end{tabular}

\section{A pDNS molekulatömege}

Megvizsgáltuk azt is, hogy milyen változás történik a nanorészecske méretében, ha a benne lévő plazmidot kicseréljük. A kísérlethez minden mintánál ugyanazt a PEIm-et és formulációs oldószert használtuk, a következö méretü pDNS-ekkel: 4; 6; 6,5; 6,7 és 12,5 kilóbázispár. A szokott módon készített nanorészecskéknek megmértük a részecskeméretét (10. Táblázat).

10. Táblázat. A PEIm különböző méretű pDNS-ekkel alkotott nanorészecskéinek effektív átmérői.

\begin{tabular}{ccc}
\hline pDNS & $\begin{array}{c}\text { pDNS mérete } \\
(\mathbf{k B p})\end{array}$ & $\begin{array}{c}\mathbf{D}_{\text {Eff }} \pm \mathbf{S D} \\
(\mathbf{n m})\end{array}$ \\
\hline pJET & 4 & $254 \pm 8$ \\
pGL2 & 6 & $249 \pm 5$ \\
pRED & 6,5 & $233 \pm 10$ \\
pcOVA & 6,7 & $166 \pm 4$ \\
pLWXu1 & 12,5 & $172 \pm 43$
\end{tabular}


Az eredmények arra utalnak, hogy a plazmid cseréje a poliplex méretét nem befolyásolja, vagyis annak méretétől nem függ a kialakuló nanorészecske átmérője. Mind az öt különböző méretü pDNS, bár hatalmas mérettartományt (2,6-8 MDa) fednek le, 150-300 $\mathrm{nm}$ méretủ nanorészecskéket alakítanak ki. Nem csak a részecskeméret, hanem a méreteloszlás is hasonló, minden plazmid esetében egy kisebb és egy nagyobb mérettartomány jelenik meg, tehát bimodális jellegü. Az ötből három nanorészecske reprezentatív intenzitás szerinti eloszlását a 11. Ábra mutatja.

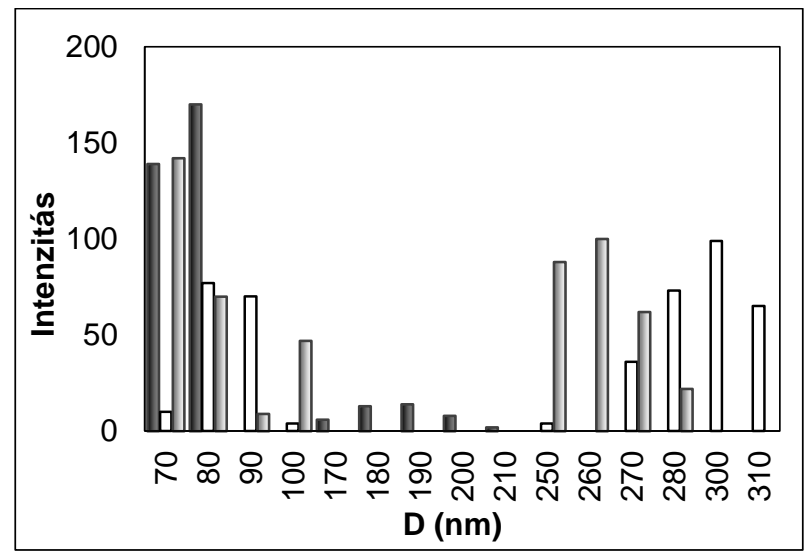

10. Ábra. Különbözö molekulatömegü pDNS-ekből ugyanazzal a PEIm-mel és pufferrel készített DermaVirek intenzitás szerinti méreteloszlása: - $\mathbf{- p L W X u 1}(12,5 \mathrm{kBp}), \square$ - pcOVA (6,7 kBp), $\square$ - pJet (4 $\mathrm{kBp})$.

Ez a paraméter azért fontos, mert mivel a pDNS/PEIm nanorészecske platformtechnológia, vagyis hasonló hatásmechanizmussal más betegségek kezelésére is alkalmas lehet, ha a pDNS-be más információt kódolunk, elvárt, hogy a részecskeméret a vírusokra jellemző 100-300 nm-es tartományban legyen akkor is, ha kisebb vagy nagyobb plazmid kerül a PEIm mellé. A hatásmechanizmus fontos lépése, hogy a részecskét a szervezet kórokozóként ismerje fel és endocitózis útján jusson a sejtbe, ehhez pedig nélkülözhetetlen, hogy a részecske átmérője a fent említett mérettartományba essen. A DermaVir mellett a másik ,prototípus”, a DermAll, az ovalbumin allergén elleni nanomedicína, ami sikeresen igazolta eddig egérben, hogy a specifikus immunterápia más megbetegedések kezelésére is alkalmas lehet, mint például az allergia. A DermAll 
nanomedicína a fenti plazmidok közül a pcOVA-t tartalmazza, melyet a PEIm a pLWXu1hez hasonló módon kondenzál nanorészecskévé. ${ }^{93}$

Bizonyítottuk tehát, hogy a plazmid DNS nagysága és topoizomereinek aránya nem befolyásolja a kondenzáció során kialakult nanorészecske méretét ezektől a paraméterektől függetlenül képes kialakulni a kompakt nanorészecske.

A pDNS komponens vizsgálata során felderített kritikus paraméterrel, a nátrium mennyiségére vonatkozó határértékkel bővült a specifikáció (11. Táblázat). Emellett, mivel régóta ismert az irodalomban, hogy a fémionok egy része katalizálhatja a pDNS hidrolízisét, illetve degradációját, bekerült a specifikációba egy fémionokra vonatkozó határérték is. ${ }^{108,109}$

11. Táblázat. A pDNS specifikációjába újonnan bekerült paraméterek.

\begin{tabular}{lcc}
\hline \multicolumn{1}{r}{ Paraméter } & Módszer & Elfogadási kritérium \\
\hline Na & ICP-MS & $<100 \mathrm{ppm}$ \\
Fém szennyezők & ICP-MS & $<0,1 \mathrm{ppm}$ \\
\hline
\end{tabular}




\subsubsection{A DermaVir nanorészecske}

\section{A formulációs oldószer megválasztása}

Más formulációs oldószer választása a glükóz helyett nem volt kérdéses, mivel az a fent már említett probléma miatt nem alkalmazható stabil formuláció készítéséhez. A megfelelő helyettesítő kiválasztása azonban nem magától értetődő. A hatóságok elvárásai szerint a legegyszerübb volna a cukoroldatot injekciós vízre, vagy a folyadékkészítményekben leggyakrabban használt fiziológiás sóoldatra ( 0,9 tömeg\% nátrium-klorid) cserélni. Mindkét lehetőséget meg is vizsgáltuk mind fizikokémiai minőségellenőrző-, mind biológiai aktivitás vizsgálattal. Az eredmény szerint az injekciós vízzel készített részecske átmérője ugyan a vírus mérettartományban marad, biológiai aktivitása azonban csupán a glükózos kontroll fele, ami egyértelmű bizonyíték arra, hogy a cukor pozitív hatással van a formuláció biológiai aktivitására. (12. Táblázat).

12. Táblázat. A három vizsgált formulációs oldószerben formulált poliplexek effektív átmérői és relatív biológiai aktivitásaik.

\begin{tabular}{ccc}
\hline $\begin{array}{c}\text { Formulációs } \\
\text { oldószer }\end{array}$ & $\begin{array}{c}\mathbf{D}_{\mathrm{EFF}} \pm \mathbf{S D} \\
(\mathbf{n m})\end{array}$ & $\begin{array}{c}\text { Biológiai aktivitás } \\
(\mathbf{p 2 4 \%})\end{array}$ \\
\hline $\mathbf{1 0 \%}$ glükóz & $149 \pm 7$ & $100 \pm 19$ \\
& $172 \pm 5$ & $48 \pm 3$ \\
Injekciós víz & $2368 \pm 154$ & $28 \pm 5$ \\
\hline $\mathbf{0 , 9 \% ~ N a C l}$ & & \\
\hline
\end{tabular}

A fiziológiás sóoldatban a kialakuló poliplexek a mikrorészecskék tartományába esnek, és feltehetően pont emiatt, a biológia aktivitás csupán 28\%-ot ér el a glükózos kontrollhoz képest. A megnövekedett részecskeméret arra kényszeríti a részecskét, hogy más utat válasszon a sejtbe való bejutásra, mint az egy-kétszáz nanométeres részecskék: az ilyen hatalmas méretűeket a sejt már csak pinocitózis vagy fagocitózis útján képes felvenni. ${ }^{89,110}$ Az ilyen alternatív folyamatok azonban lassabb folyamatok (kinetikailag kevésbé kedvezményezettek), ezért azonos körülmények között kisebb biológiai aktivitást mutatnak 
az így bejutó részecskék, mintha a poliplex receptoron keresztül lép be a sejtbe. ${ }^{13}$ Elméletünk szerint a fiziológiás sóoldatban való méretnövekedés oka, hogy a részecskék aggregálódnak, mivel a megnövekedett ionerősségű oldatban az ionok a polielektrolitokra adszorbeálódva képesek azokat összekötni és másodlagos kötéseken keresztül laza aggregálódott szerkezetet alakítanak ki. Erre bizonyíték az a megfigyelés, hogy az UV spektrumok alapján a fiziológiás sóoldatban formulált részecskék koncentrációja csökken, a poliplexek fokozatos aggregációja ugyanis egy idő után ahhoz vezet, hogy a túlságosan nagyra nőtt részecskék kiülepednek és kicsapódnak.

Mivel a fenti eredmények azt mutatták, hogy a formulációban szükség van cukorra, viszont a PEIm-mel való mellékreakciót ki kellett küszöbölni, olyan lehetséges jelöltmolekulákat teszteltünk, mint a szorbit, szacharóz és a mannitol. Ezek mind cukoralkoholok, vagyis nem tartalmaznak redukáló csoportot, így indifferensek a polimer nitrogénjeire nézve. Mindhárom választott poliol megtalálható a gyógyszerkönyvben, így regulációs oldalról is jó választás lehet bármelyik. A készített formulációkat ismét a glükóz-tartalmúhoz hasonlítottuk, és az eredmény azt mutatta, hogy a mannitolt, illetve a szacharózt tartalmazók minden paraméterükben megfeleltek: mind a fizikokémiai tulajdonságok, mind a biológiai aktivitás szempontjából, de a szorbit-tartalmú formuláció biológiai aktivitása kisebb volt, csupán 53\%-át éri el a kontrollnak (13. Táblázat).

13. Táblázat. A vizsgált formulációs oldószerekkel készített nanorészecskék effektív átmérői és relatív biológiai aktivitásaik.

\begin{tabular}{ccc}
\hline $\begin{array}{c}\text { Formulációs } \\
\text { oldószer }\end{array}$ & $\begin{array}{c}\mathbf{D}_{\mathrm{Eff}} \pm \mathbf{S D} \\
(\mathbf{n m})\end{array}$ & $\begin{array}{c}\text { Biológiai aktivitás } \\
(\mathbf{p 2 4 \%})\end{array}$ \\
\hline $\mathbf{1 0 \%}$ glükóz & $110 \pm 3$ & $100 \pm 18$ \\
$\mathbf{1 0 \%}$ mannitol & $179 \pm 10$ & $100 \pm 10$ \\
$\mathbf{1 0 \%}$ szacharóz & $191 \pm 2$ & $105 \pm 12$ \\
& $167 \pm 8$ & $53 \pm 3$ \\
\hline
\end{tabular}


Erre a csökkent biológiai aktivitásra magyarázatot nem találtunk. A két jól szereplő cukoralkohol közül a mannitolt választottuk, mivel ez kémiailag inkább hasonlít az eddig használt glükózhoz, mint a két gyürüt tartalmazó szacharóz.

Három napos szobahőmérsékletü tárolás során bebizonyosodott az is, hogy a várakozásnak megfelelően mannitollal spektrofotometriásan nem detektálható a Maillard-reakció termékére jellemző csúcs 365 nm-nél, ellentétben a glükózzal formulált formulációval (11. Ábra, A).

A

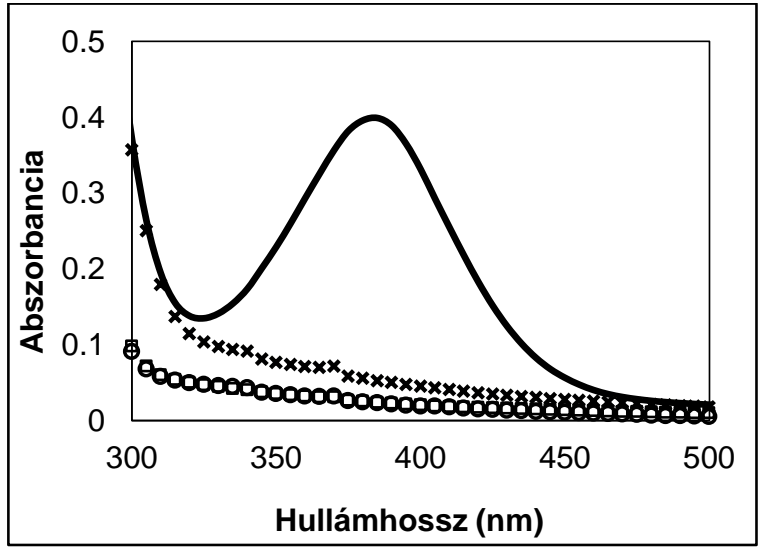

$\mathrm{B}$

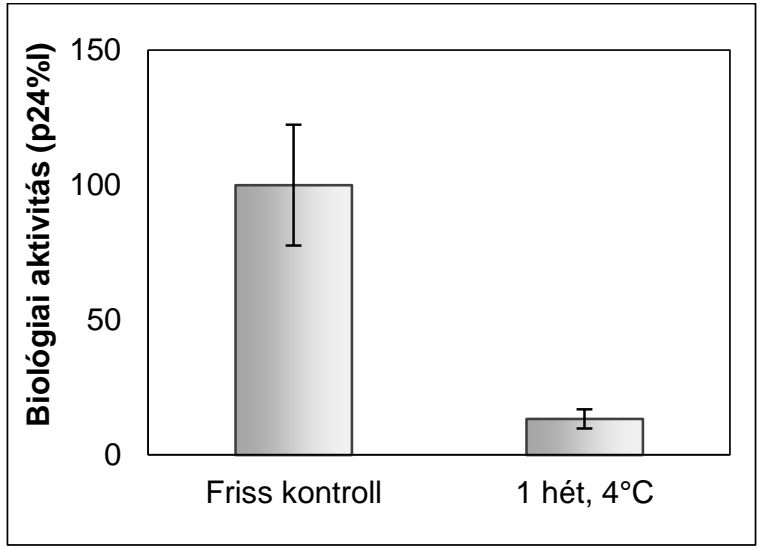

11. Ábra. A mannitolos-, illetve glükózos formulációk stabilitás-különbsége. A) A mannitollal és a glükózzal formulált DermaVirek UV-vis spektrumai a kérdéses tartományban: a mannitollal formulált DermaVir 20 perc után (०), a mannitollal formulált DermaVir 3 nap után $(\square)$, a glükózzal formulált DermaVir 20 perc után $(\times)$, a glükózzal formulált DermaVir 3 nap után $(-)$. B) A mannitollal formulált DermaVir biológiai aktivitása frissen és 1 hetes $4^{\circ} \mathrm{C}$-on történő tárolás után ( $100 \%$ a friss kontroll).

A mannitol azonban nem oldott meg minden problémát, mivel a pár órán túl való stabilitás továbbra is problémás maradt, bár nem melléktermék megjelenése, hanem a tárolás során csökkenő biológia aktivitás miatt (11. Ábra, B). Ezt annak tulajdonítottuk, hogy a formuláció pH-ja meglehetősen alacsony, 3,5-4 közötti, ami nem szolgálja a részecskék stabilitását, mivel a pDNS depurinizációja, illetve a $\beta$-elimináció első lépése is savkatalizált folyamatok. ${ }^{60}$ Ezért tehát a megfelelő cukor mellett egy puffert kellett találni, amely a megfelelő $\mathrm{pH}$ beállítása mellett a rendszer egészére és a komponensekre nézve külön-külön is indifferens. A pDNS szempontjából a pH az irodalom szerint 6 és 9 között 
lenne megfelelő, mivel itt a pDNS stabilan eltartható. ${ }^{60,61}$ Azonban a szokásos, biológiai rendszereknél használt pufferek között kevés olyan található, amely összeférhető lenne a DermaVir komponenseivel, vagy a részecskével magával. A PBS-t, vagyis a $\mathrm{NaCl}$ tartalmú foszfát puffert rögtön kizártuk, mert bár az egyik leggyakrabban alkalmazott közeg plazmidok mellett, magas NaCl-tartalma a fent leírtak miatt alkalmatlanná teszi a DermaVir nanorészecskék formulálására. A másik probléma, hogy a benne lévő foszfátion kompetícióba léphet a pDNS-sel a PEIm-hez való kötődésért, ami egy idő után ahhoz vezethet, hogy a részecskék szétesnek, amikor a foszfát teljesen kiszorítja a pDNS-t a PEIm szekunder aminjairól.

Az egyik lehetséges, és szintén gyakran alkalmazott puffer a Tris-HCl puffer (2amino-2-hidroximetil-propán-1,3-diol hidroklorid), ami a megfelelő pH-tartományban használható, 7 és 9 között. $10 \mathrm{mM}$ koncentrációjú, 7,9-es pH-jú Tris-HCl pufferrel formulált DermaVirt vizsgáltunk (12. Ábra). A friss Tris-HCl pufferes poliplex biológiai aktivitása a glükózos kontrollnak csupán 50\%-át érte el (12. Ábra, A), és 6 napos, szobahőmérsékleten történő tárolás során a részecske mérete a duplájára nőtt (12. Ábra, B). A részecske növekedése mellett a másik probléma, hogy a tárolt részecskék nátriumdodecil-szulfáttal (SDS-sel) történő dekomplexálása a friss poliplexhez képest csökkent pDNS mennyiséget mutatott (12. Ábra, C). A gélen látható kontroll (\#3-5 zseb) és a tárolt (\#7-9 zseb) minták sávjainak intenzitás-különbsége a pDNS részleges kicsapódását feltételezi. Ezt az is alátámasztja, hogy a poliplex frissen 260 nm-en mért abszorbanciája (A260 értéke) lecsökken a tárolás során, körülbelül a harmadára (12. Ábra, D).

A

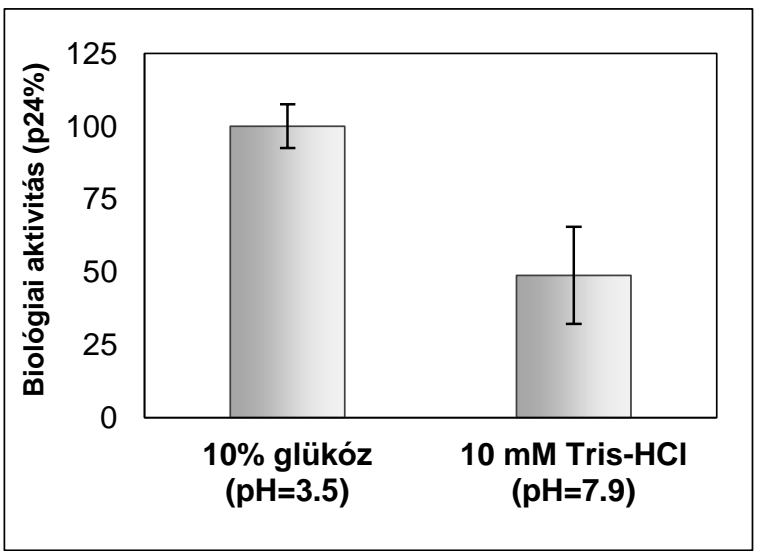

B

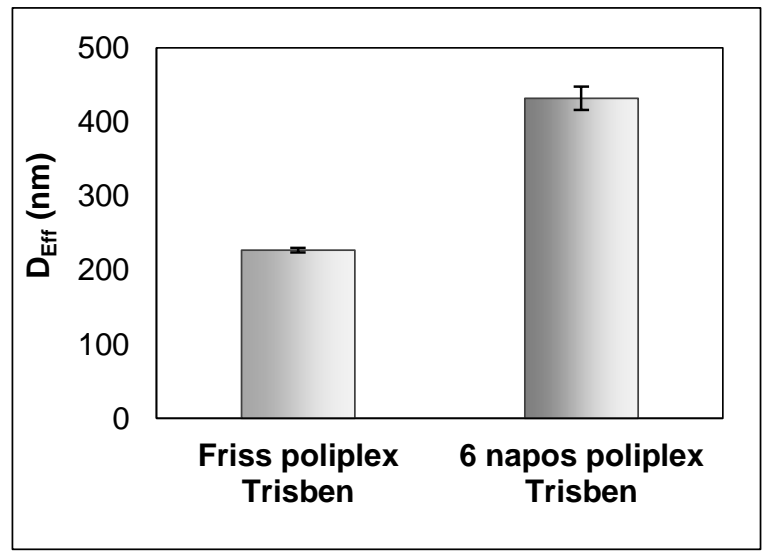


$\mathrm{C}$

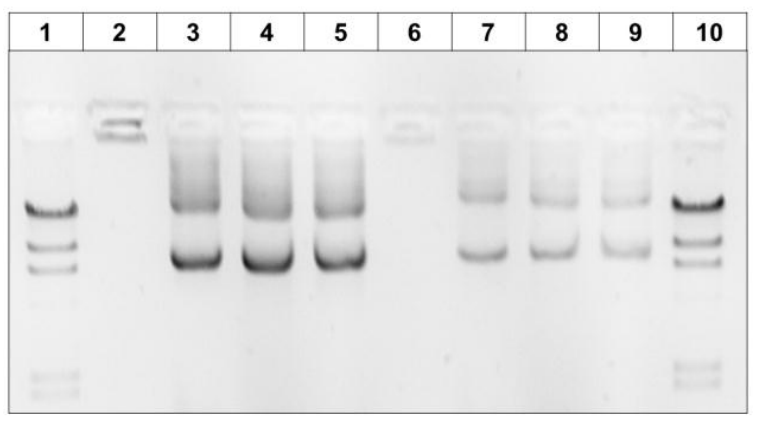

$\mathrm{D}$

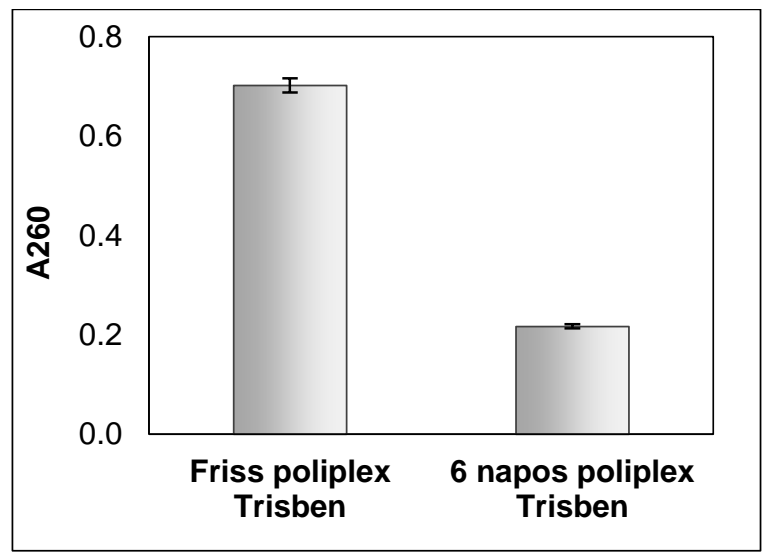

12. Ábra. A Tris-HCl tesztelése formulációs oldószerként. A) Relatív biológia aktivitás a glükózos formulációhoz képest. B) Friss és 6 napig szobahőmérsékleten tárolt részecskék részecskemérete. C) 6 napig szobahőmérsékleten tárolt Tris-ben formulált részecskék dekomplexálás után, agaróz gélen vizsgálva. Zsebek: \#1-marker; \#2-DermaVir glükózzal formulálva; \#3-5-friss glükózos DV dekomplexálva; \#6DermaVir Tris-szel formulálva; \#7-9-tárolt Tris-es DV dekomplexálva; \#10-marker. D) Friss és 6 napig szobahőmérsékleten tárolt formulációk 260 nm-en mért abszorbanciái.

A Tris- $\mathrm{HCl}$ puffer tehát nem vált be sem rövid, sem hosszabb távon. A Tris összeférhetetlensége a DermaVir rendszerrel nem meglepö, ha meggondoljuk, hogy a Tris primer aminja erősebb bázis, mint a PEIm (annak szekunder aminjai), így a polimerrel versengve kiszorítja azt a pDNS mellől, az inkubációs idő növelése pedig ebben a folyamatban a Tris-nek kedvez, mivel sokkal magasabb koncentrációban van jelen az oldatban. Így tehát a meglazuló poliplex részecskék aggregálódnak, összetapadnak, ezért látjuk a részecskeméret növekedését, ami kicsapódáshoz vezet, ahogy a gélelektroforézis és az UV mérés is bizonyítja.

A következő puffer-jelölt a trietanolamin és annak hidroklorid sója volt (TEA/HCl). A trietanolamin egy gyenge bázis, amely egy tercier nitrogént tartalmaz, így nem lép kompetícióba a PEIm-mel, emellett 7,3-8,3 pH-tartományban megfelelő a pufferkapacitása, mindezek mellet gyógyszerkönyvi kompendium. Készítettünk tehát egy 10 mM-os TEA/HCl puffert, melynek pH-ját 7,5-re állítottuk be. Ezzel egy időben még egy formulációs oldószert készítettünk, mégpedig úgy, hogy a fenti 7,5-os pH-jú TEA/HCl pufferbe beoldottunk 10 tömeg\% mannitolt (TEAM puffer), ami ötvözi a pH-puffer és a cukorszerü molekula már korábban vizsgált előnyeit. Ezután elvégeztük az analitikai 
vizsgálatokat, melyekben kontrollként a $10 \%$ glükózos eredeti, illetve a már korábban vizsgált $10 \%$ mannitolos formulációkat használtuk. Az eredményeket a 13. Ábra mutatja. A részecskeméret-mérések alapján mind a 4 vizsgált formuláció 160 és $170 \mathrm{~nm}$ közötti átlagos effektív átmérőt mutatott, ebben tehát nem találtunk eltérést (13. Ábra, A). Az in vitro biológiai aktivitás tesztben (13. Ábra, B) azonban azt találtuk, hogy a glükózos formulációhoz hasonló mértékű aktivitást mutat a mannitolos, illetve a TEAM-os formuláció (hasonló volt a helyzet abban az esetben is, amikor a mannitol helyett 10 tömeg\%-nyi glükózt oldottunk a TEA/HCl-be, ekkor a biológiai aktivitás 104 $\pm 15 \%$ volt). A TEA/HCl puffer a cukor/cukoralkohol nélkül szignifikánsan alacsonyabb, mindössze 60\%-os potenciát ért el $(\mathrm{p}=0,037)$. Ezt a csökkent aktivitást a cukor-szerü molekulák pDNS-re gyakorolt stabilizáló hatásával magyarázhatjuk. ${ }^{111}$

A

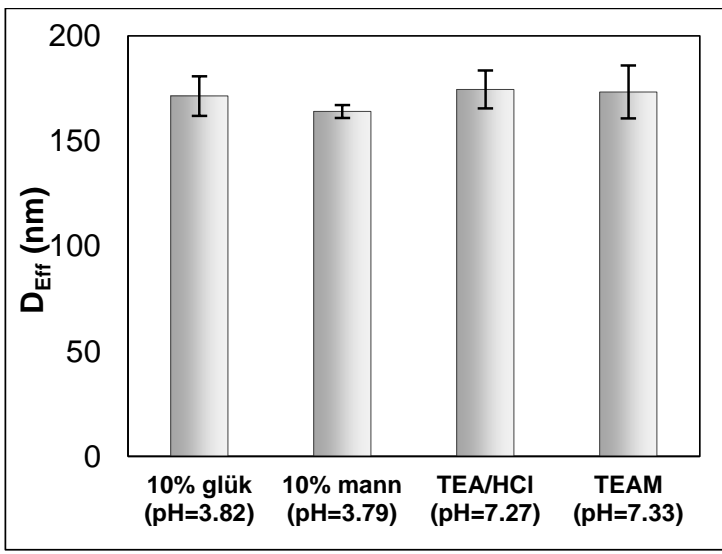

B

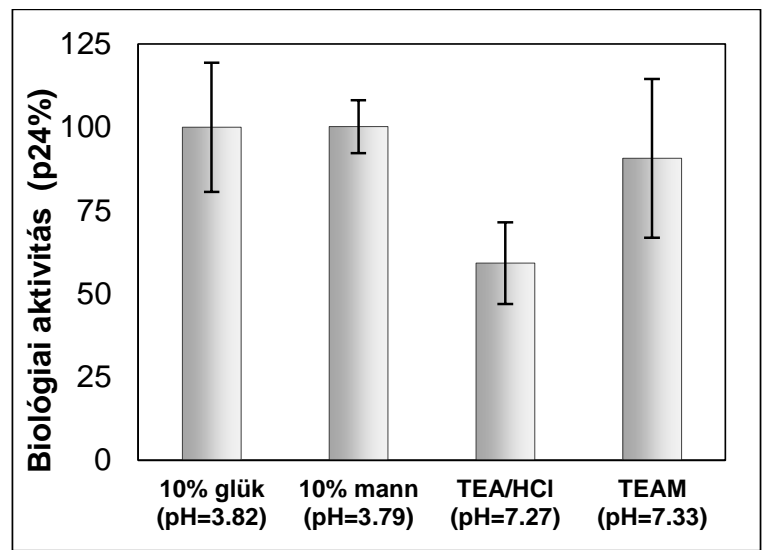

13. Ábra. A trietanolamin-hidroklorid puffer $(\mathrm{TEA} / \mathrm{HCl})$ és a mannitol tartalmú trietanolamin-hidroklorid puffer (TEAM) tesztelése a nanomedicína formulációs oldószereként. A) Effektív átmérő eredmények a 4 vizsgált formulációnál. B) In vitro biológiai aktivitás eredmények a 4 vizsgált formulációnál a glükózzal készített kontrollhoz képest.

Megtaláltuk tehát az ideális cukoralkohol-tartalmú puffert a glükóz lecserélésére, azonban annak optimális pH-ját is meg kellett határozni. Mivel a különböző pH-jú közegek hatását igazán csak hosszabb távú, tárolásos kísérletekben lehet vizsgálni, hogy a minőségbeli különbségek jobban mérhetőek legyenek, elindítottunk egy $+4^{\circ} \mathrm{C}$-os, egy hetes stabilitás vizsgálatot, melyhez az alábbi pH-jú puffereket használtuk: 3,6; 3,9; 5,2; 
6,2; 7,0; 7,5; 8,0; 9,3. Ez a nyolc vizsgált érték persze nagyon széles $\mathrm{pH}$ tartományt fed le, és a TEAM nem minden ponton képes pufferelni (így ebben a kísérletben oldatnak nevezzük); pH 3-7 között nem pufferel ugyan, de így tervezve a kísérletet azonos kémiai összetételü formulációkat tesztelhettünk, melyek egyedül a pH-ban térnek el. A stabilitás vizsgálat elindításánál teszteltük a mintákat (friss), majd egy hét elteltével újra (14. Ábra). A frissen készített DermaVireknek mind hasonló biológiai aktivitása (14. Ábra, A) és részecskemérete (14. Ábra, B) volt, azonban már ekkor is kiemelkedő a 6-7,5 pH régióban szerepelő minták aktivitása. Az adatsorra parabola illeszthető, melynek maximuma 6,2-es pH-nál van. Az egy hetes tárolás után hasonló trendet kaptunk (a formulációk pH-ja a tárolás során nem változott). Mivel tárolás után a 7 és a 7,5-es pH-kra mértük a maximumot, és a TEA/HCl puffertartománya 7,3 és 8,3 között van, így a 7,5 \pm 0,2-es pH-t állapítottuk meg elfogadási kritériumnak.

A

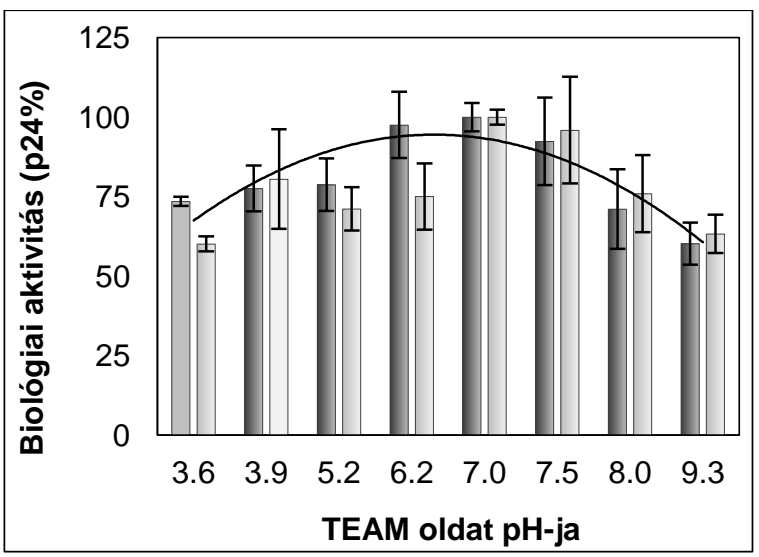

$\mathrm{B}$

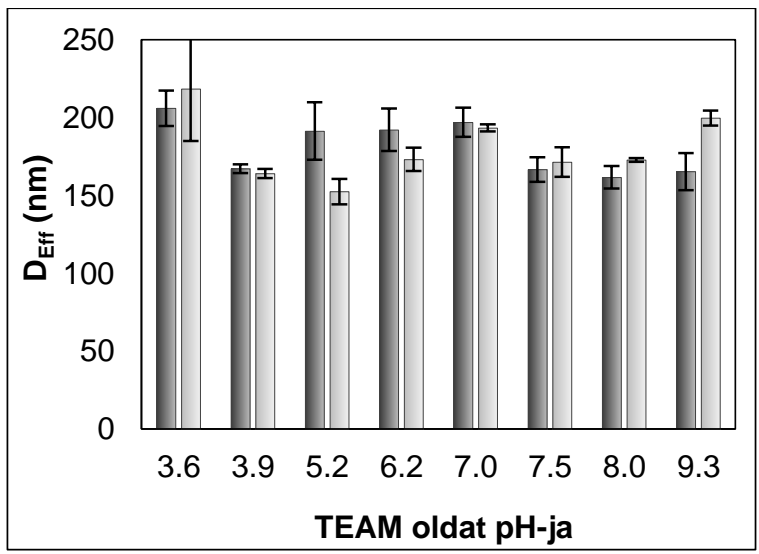

14. Ábra. Különböző pH-jú TEAM oldattal formulált nanorészecskék egy hetes, $4^{\circ} \mathrm{C}$-os stabilitás vizsgálata.

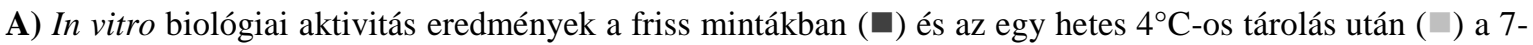
es pH-jú TEAM-ot tartalmazó formulációhoz képest $\left(\mathrm{y}=-3,5344 \mathrm{x}^{2}+43,71 \mathrm{x}-41,146, \mathrm{R}^{2}=0,7533\right)$. B) Effektív átmérő eredmények a friss mintákban $(\square)$ és egy hetes $4{ }^{\circ} \mathrm{C}$-os tárolás után $(\square)$.

Az újonnan kiválasztott TEAM puffer stabilizáló hatását megvizsgáltuk a pDNS-re magában is, két másik gyakran használt puffer/oldat; $10 \mathrm{mM}$ Tris, illetve $1 \mathrm{mM}$ EDTA mellett. Az eredmény szerint a TEAM bizonyult a leghatásosabbnak: míg a Tris-ben $(\mathrm{pH}=7,8)$ tárolt pDNS 4\%, az EDTA-ban tárolt 3\%, a kontroll puffermentes 0\%, a TEAM- 
mal hígított plazmid ( $\mathrm{pH}=7,4)$ 33\%-nyi szuperhelikális formát tudott megőrizni egy hetes $37^{\circ} \mathrm{C}$-os tárolás alatt, ami jól mutatja, hogy a választott pufferoldat képes stabilizálni a pDNS-t (is).

Hogy még tovább stabilizáljuk a részecskét, megvizsgáltuk az EDTA-t a poliplex rendszer stabilizátoraként is mivel az EDTA köztudottan növeli a pDNS eltarthatóságát. ${ }^{60}$ Az eredmény meglepő lett, ugyanis az EDTA nemhogy nem stabilizálta a poliplexet, de jelenlétében nem tudott kialakulni a nanorészecske, annak ellenére, hogy csak 1 mM-os, meglehetősen alacsony koncentrációban volt jelen (15. Ábra). A részecskeméret a mikrométeres tartományban volt, a biológiai aktivitás pedig a töredékét érte csak el az EDTA-t nem tartalmazó kontrollénak. Ez az eredmény azzal magyarázható, hogy a kelátképző ágens EDTA fogai képesek bekötni a PEIm kationos nitrogénjeihez, így csökkentve a foszfáttal kialakítható kötések számát. Ez a magyarázat a mikroméretre is magyarázatot ad, ugyanis az EDTA bekötődésével a polimert sztérikusan gátolja, nem alakulhat ki kicsi, kompakt nanorészecske.

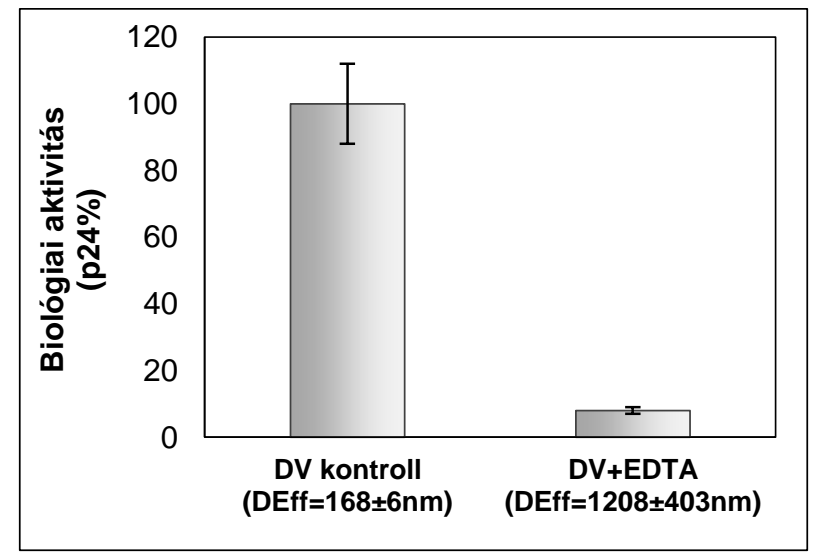

15. Ábra. Az EDTA hatásának vizsgálata az új formulációs DermaVirre. Az EDTA-val készített DermaVir és az EDTA-mentes kontroll relatív biológiai aktivitása a kontrollhoz képest.

\section{$\underline{\text { A komponensek aránya (N/P arány) }}$}

A nanorészecske egészének vizsgálata során a pDNS és a PEIm komponensek arányát (N/P arány) is tanulmányoztuk, mivel megfigyeltük, hogy egyes esetekben a 
tárolás során javul a nanorészecskék minősége. Eredményeink szerint, a 2-es N/P arányú részecske biológiai aktivitása az egy hetes, szobahőmérsékleten történő (RT) tárolás alatt javult (16. Ábra). Ezt a magasabb, 3-as és 4-es N/P arányú poliplexeknél nem tapasztaltuk. Feltehetően a 2-es N/P arányú részecske esetében a tárolás során történő stabilizálódás okozza a javulást, mert a PEIm alacsonyabb mennyisége miatt itt több idő szükséges a stabil részecske kialakulásához, az egyensúly beálltához (16. Ábra, A). 2-es N/P aránynál a friss részecske mérete nagy, körülbelül 400 nm-es és a szórása is magas, ami inhomogén rendszert sejtet. Egy hetes tárolás után viszont a méret már a vírus mérettartományba esik, $280 \mathrm{~nm}$, és szórása is lecsökken (16. Ábra, B). Ezeknek a diszkrétté vált nanorészecskéknek már a biológiai aktivitása is jóval magasabb, majdnem a kétszerese a frissen mért értéknek (16. Ábra, A). Ezzel ellentétben 3-as N/P aránynál a tárolás során a biológiai aktivitás szignifikánsan csökkent $(\mathrm{p}<0,003)$, míg 4-es $\mathrm{N} / \mathrm{P}$ aránynál állandó maradt. Ezekből az eredményekből arra a következtetésre jutottunk, hogy az ideális N/P arány a formulációban az eddig is alkalmazott 4-es. Ezeken felül a magasabb N/P arányok a náluk megfigyelt emelkedett toxicitás miatt nem szerencsések. ${ }^{112,113,114}$

A

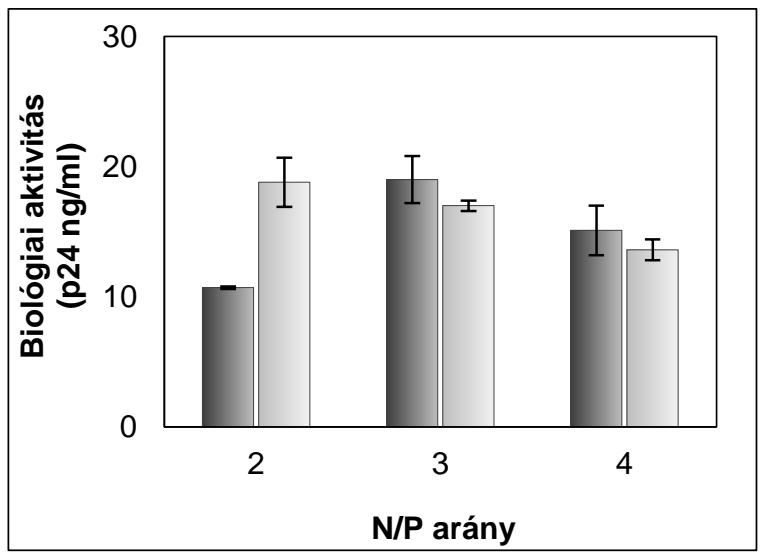

B

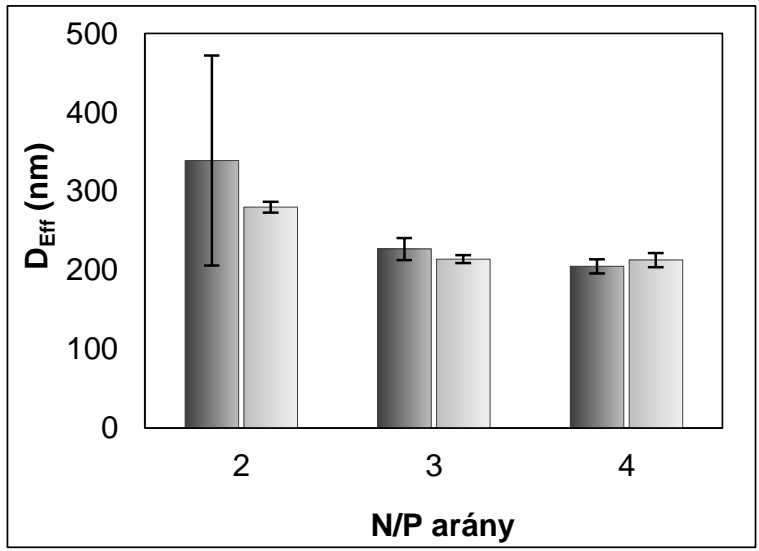

16. Ábra. $\mathrm{N} / \mathrm{P}=2,3$, illetve 4-es nanorészecskék frissen kevert (匹), és egy hetes ( $\square)$, szobahőmérsékletü (RT) tárolása során mért A) biológiai aktivitásai és B) részecskeméret eredményei.

Stabilitás vizsgálatok 
Miután optimalizáltuk a PEIm és a pDNS komponenseket, illetve az eddigi problémás formulációs oldószer glükóz oldatot lecseréltük a mannitoltartalmú, 7,5-ös pH-jú trietanolamin-hidroklorid pufferre, elkezdhettük a stabilitás vizsgálatokat; a rendelkezésre álló kétféle PEIm és kétféle pDNS különböző kombinációkban történő formulálásával létrejövő nanorészecskék tulajdonságait hosszabb távon megfigyelve. Elindítottunk egy 3, illetve 8 hetes stabilitás vizsgálatot $37^{\circ} \mathrm{C}$-on és $4^{\circ} \mathrm{C}$-on. Négy fajta DermaVirt készítettünk, melyek összetételét a 14. Táblázat összegzi.

14. Táblázat. A vizsgált 4 féle formuláció összetétele (formulációs oldószer mindnél a 7,5-ös pH-jú TEAM puffer volt).

\begin{tabular}{ccc}
$\begin{array}{c}\text { Poliplex } \\
\text { neve }\end{array}$ & $\begin{array}{c}\text { pDNS } \\
\text { komponens }\end{array}$ & $\begin{array}{c}\text { PEIm } \\
\text { komponens }\end{array}$ \\
\hline DV_11 & pDNS-1 & PEIm-1 \\
DV_12 & pDNS-1 & PEIm-2 \\
DV_21 & pDNS-2 & PEIm-1 \\
DV_22 & pDNS-2 & PEIm-2 \\
\hline
\end{tabular}

A 3 hetes tárolás után a DV_11 részecske (vagyis a klinikai anyagok: 90\%-ban protonált PEIm és 6 molekvivalens $\mathrm{NaCl}$-ot tartalmazó pDNS) szignifikánsan kisebb biológiai aktivitást mutatott a friss kontrollhoz képest (17. Ábra, A). A DV_12 részecske (vagyis 60\%-ban protonált PEIm és 6 molekvivalens NaCl-ot tartalmazó pDNS) tárolás után kevésbé romlott, mint a DV_11, de ez is csupán 60\%-át érte el a frissen készített kontrollnak. Ennél az utóbbi formulációnál érdekesség, hogy a $37^{\circ} \mathrm{C}$-on illetve a $4^{\circ} \mathrm{C}$-on tárolt minták között nem volt különbség, egyforma mértékben vesztettek biológiai aktivitásukból a 3 hetes inkubáció alatt, vagyis a tárolási hőmérséklet (a vizsgált tartományban) nem befolyásolta a stabilitást (17. Ábra, B). 
A

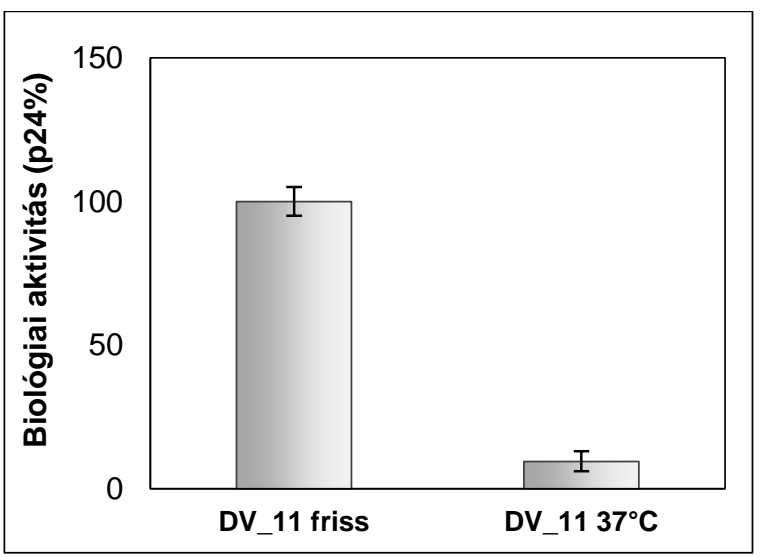

$\mathrm{B}$

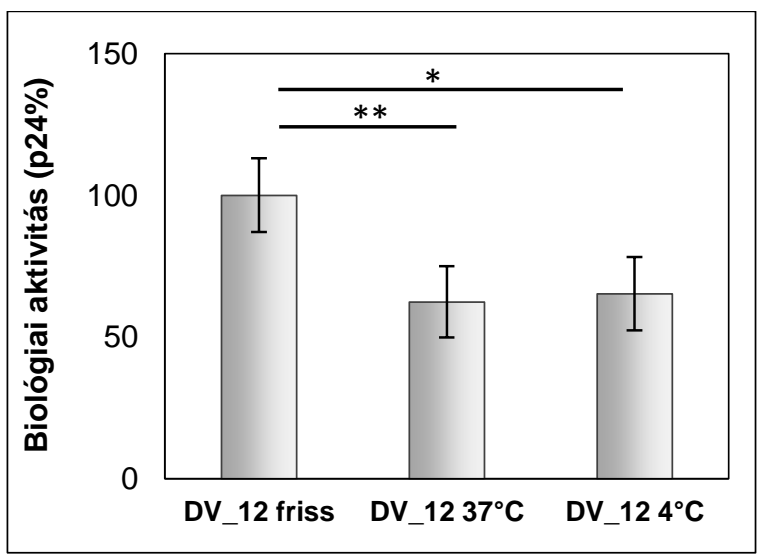

17. Ábra. pDNS-1-el készített nanorészecskék relatív biológiai aktivitásai 3 hetes tárolás után a friss kontrollokhoz képest A) PEIm-1-el ( $\mathrm{p}<0,0001)$, B) PEIm-2-vel (*p=0,032; **p=0,022).

A pDNS szuperhelikális formájának arányát $(\mathrm{ccc} \%)$ is vizsgáltuk a részecskén belül, illetve annak a tárolás során történő változását (15. Táblázat). Leginkább a DV_11 részecske esetében találtuk a pDNS részleges degradációját, ebben 14,2\%-ra csökkent a kiindulási 78,6\%-ról, illetve a DV_12-nél 48,4\%-ig fogyatkozott a szuperhelikális topoizomer százalékos aránya. Ez a mértékủ ccc\% csökkenés oka lehet a csökkent biológiai aktivitásnak, mint azt fent láttuk.

15. Táblázat. A vizsgált pDNS-1 tartalmú részecskék 3 hetes tárolása után a poliplexek dekomplexálásával mért ccc\%-ok a bennük található pDNS-ekre.

\begin{tabular}{ccccc}
\hline Poliplex/pDNS & pDNS & pDNS-SDS & DV_11 (37 $\left.{ }^{\circ} \mathbf{C}\right)$ & DV_12 (37 $\left.{ }^{\circ} \mathbf{C}\right)$ \\
\hline Cec\% & 78,6 & 80,5 & 14,2 & 48,4 \\
\hline
\end{tabular}

Mind a DV_11, mind a DV_12 formulációknál megfigyeltünk aggregációt is (355 nm-es részecskeméretet hatalmas szórással), ami nagy valószínűséggel szintén szerepet játszott a biológiai aktivitás csökkenésében. Összefoglalva tehát mindkét formulációban a magas ionerősségű pDNS szerepelt (a 6 molekvivalens NaCl-ot tartalmazó) és egyik PEIm-mel készített nanorészecskéje sem tudta megőrizni stabilitását. 
A DV_21 (90\%-ban protonált PEIm-mel és 0,3 ekvivalens NaCl-ot tartalmazó pDNS-sel) aktivitása szintén meglehetősen leromlott, a 3 hetes $37^{\circ} \mathrm{C}$-os tárolás után csupán a friss kontroll 12\%-át érte el (18. Ábra, A). A DV_22 formuláció azonban (60\%os PEIm és 0,3 ekvivalens NaCl-ot tartalmazó pDNS) a 3 hetes tárolás után is ugyanolyan biológiai aktivitást mutatott, mint frissen, függetlenül attól, hogy $4^{\circ} \mathrm{C}$-on, vagy $37^{\circ} \mathrm{C}$-on inkubáltuk (18. Ábra, B). A DV_22 formuláció tesztelését folytattuk tovább is, és $4{ }^{\circ} \mathrm{C}$-on 8 hét után sem lehetett biológiai aktivitás csökkenést, vagy aggregációt kimutatni (18. Ábra, C).

A

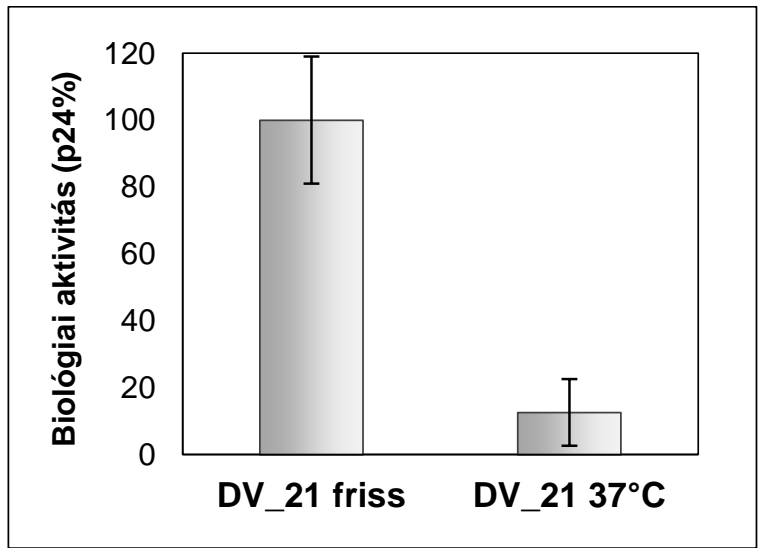

B

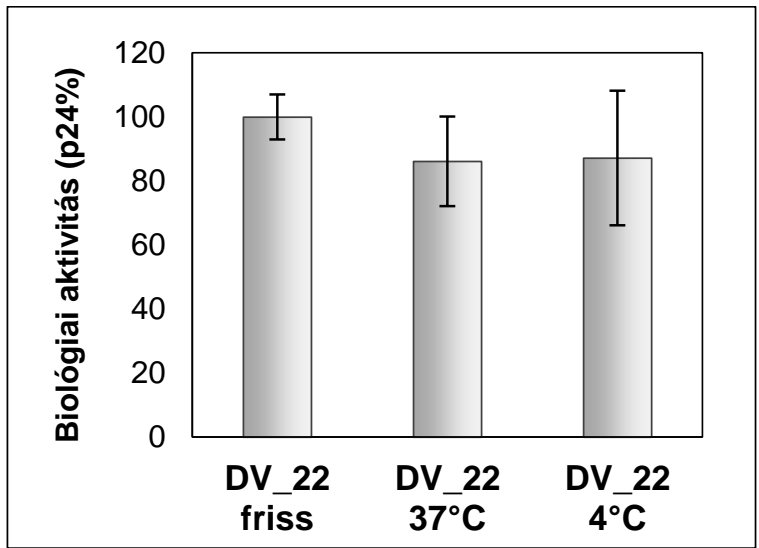

$\mathrm{C}$

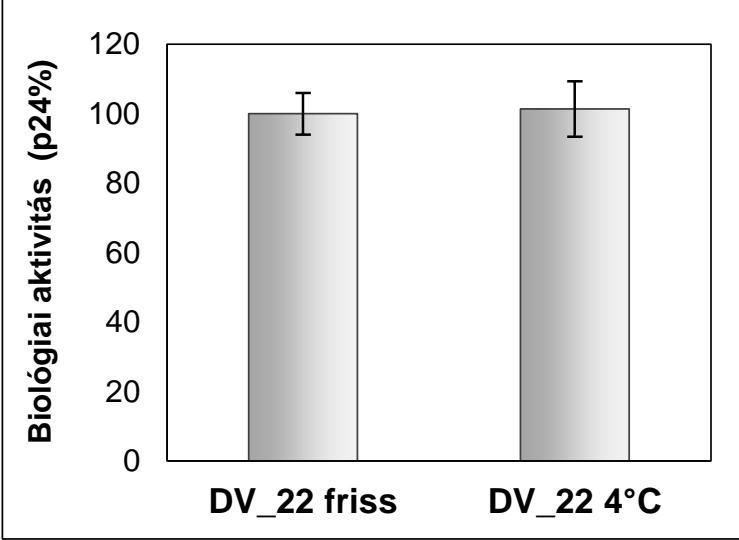

18. Ábra. pDNS-2-vel készített nanorészecskék relatív biológiai aktivitásai a frissen készített kontrollokhoz képest A) 3 hetes tárolás után PEIm-1-gyel, B) 3 hetes tárolás után PEIm-2-vel, C) 8 hetes tárolás után PEIm-2-vel. 
Kiválasztottuk tehát a DV_22 formulációt, vagyis a kis ionerősségű pDNS oldat, 60\%-os protonáltságú PEIm-mel, 7,5-ös pH-jú TEAM pufferben alkotott részecskéjét, mint új formulációt, mivel ennél az irodalomban egyedülálló 3 hetes $37^{\circ} \mathrm{C}$-os illetve 8 hetes $4^{\circ} \mathrm{C}$-os stabilitást tudtunk elérni.

Azonban nem szabad elfelejtenünk, hogy a 8 hetes $4^{\circ} \mathrm{C}$-os stabilitás adat az új folyadékformulációra bár egyedülálló eredmény, és óriási ugrás a 3 különböző hőmérsékleten tárolt jelenlegi klinikai formulációval szemben, amely pár órán keresztuil volt csupán stabil, a nemzetközi ajánlások (International Conference on Harmonization, ICH) alapján minimum 6 hónapos stabilitás adatra van szükség. Emiatt a fenti folyadékformuláció további, hosszabb távú stabilitásvizsgálatokat igényel, amivel a jövőben fogunk foglalkozni.

\section{$\underline{\text { A liofilizált formuláció }}$}

A leginkább limitáló tényező egy stabil formuláció kidolgozásában az, hogy a kész nanorészecske szuszpenzió nem fagyasztható és nem liofilizálható. Pontosabban fagyasztás után, a kiolvasztás során kicsapódik a részecske, illetve liofilizálás után nem oldódik vissza (19. Ábra).

A

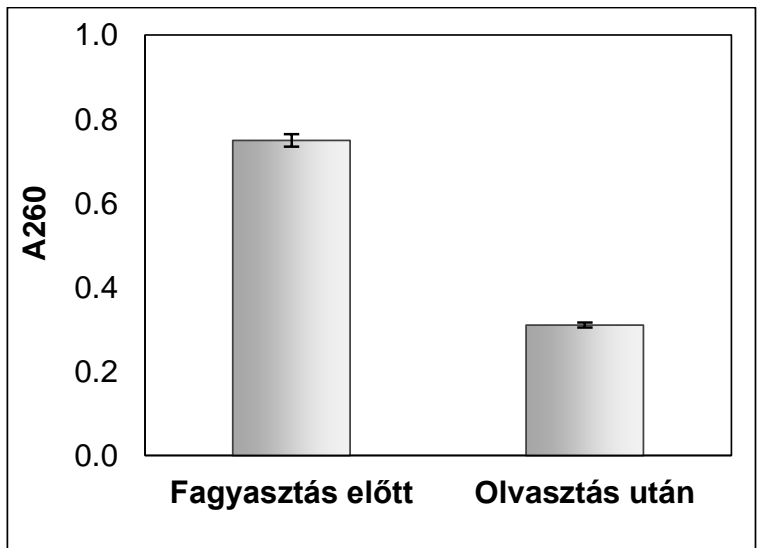

B

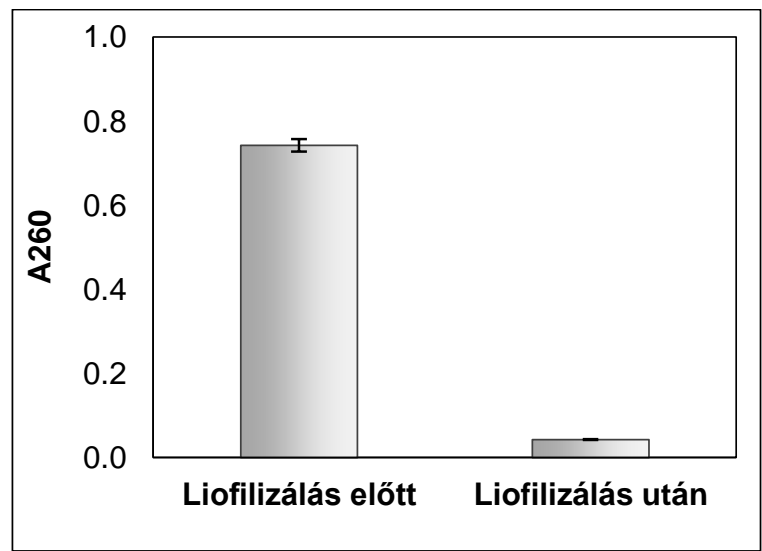

19. Ábra. DermaVir A) fagyasztás és B) liofilizálás előtti és utáni $260 \mathrm{~nm}$-en mért abszorbanciái. Az abszorbancia nagymértékủ csökkenése kicsapódásra utal. 
Pedig elméletileg mind a fagyasztás, mind a liofilizálás hosszabb távú eltarthatóságot nyújthatna, mint a folyadékformuláció. ${ }^{66}$ Ezt a fajta instabilitást a fagyasztott és liofilizált mintáknál feltehetőleg ugyanaz a jelenség okozza, miután a liofilizálás első lépése is a fagyasztás. A PEI/pDNS rendszer e problémája már ismert az irodalomban, megoldásként pedig lioprotektorokat alkalmaznak, melyekkel javítható, de teljesen nem küszöbölhető ki a probléma, mert ha a visszaoldás sikeres is, a biológiai aktivitás mégsem éri el a liofilizálás előtti mértéket. ${ }^{64,65}$ Lioprotektoroknak számítanak a poliolok, vagyis a hidroxid-csoportokban gazdag cukorszerű molekulák, mint például a trehalóz vagy a mannitol. A DermaVir szuszpenzió bár 7,5 tömeg\% mannitolt tartalmaz a végösszetételben, ez nem bizonyult elég, vagy megfelelö lioprotektornak.

Megvizsgáltuk a glicerin, mint lehetséges lioprotektor hatását a formulációra fagyasztás előtt és olvasztás után. A glicerin az egyik leggyakrabban használt stabilizátor, amit föként fehérjék mellett alkalmaznak, ráadásul gyógyszerkönyvi anyag is. ${ }^{115} \mathrm{Az}$ eredményeket az alábbi táblázat összegzi.

16. Táblázat. A TEAM-mal, illetve az 50 tömeg\% glicerint is tartalmazó TEAM-mal készített DermaVir-ek fizikokémiai tulajdonságai fagyasztás előtt és olvasztás után.

\begin{tabular}{ccc}
\hline & DV-TEAM & DV-TEAM+50\% glicerin \\
\hline A260 fagyasztás elő́tt & 0,7496 & 0,8484 \\
A260 olvasztás után & 0,3105 & 0,8147 \\
$\mathbf{D}_{\text {Eff }} \pm$ SD fagyasztás előtt $(\mathbf{n m})$ & $184 \pm 3$ & $173 \pm 4$ \\
$\mathbf{D}_{\mathrm{Eff}} \pm$ SD olvasztás után $(\mathbf{n m})$ & $9021 \pm 1000$ & $218 \pm 7$ \\
\hline
\end{tabular}

A glicerin képes volt oldatban tartani a részecskét az olvasztás után is, a csupán 4\%-os az abszorbancia-csökkenés még nem szignifikáns, és a részecskeméret is csak kis mértékben emelkedett, olvasztás után is a vírus mérettartományban van. Ezzel szemben a glicerint nem tartalmazó DermaVir A260 értéke kevesebb, mint a fele, a részecskeméret pedig majd 
2 nagyságrenddel nőtt meg az olvasztás után a kiindulási állapothoz képest, ami egyértelmúen kicsapódást jelez.

Ezután készítettünk egy TEAM puffer sorozatot 10;20;30;40; 50 tömeg\% glicerinnel, és mindből készítettünk DermaVirt, lefagyasztottuk, majd 1 hetes $-20^{\circ} \mathrm{C}$-os tárolás után megmértiik a biológiai aktivitásokat és a részecskeméreteket (20. Ábra).

A

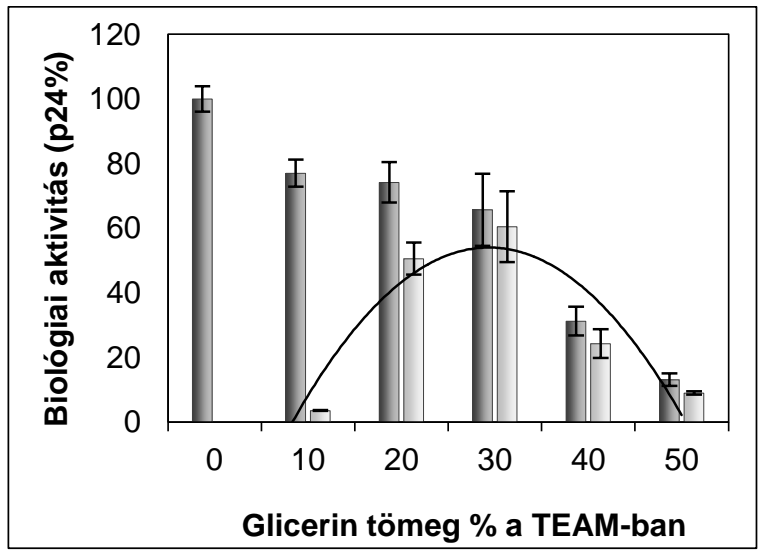

B

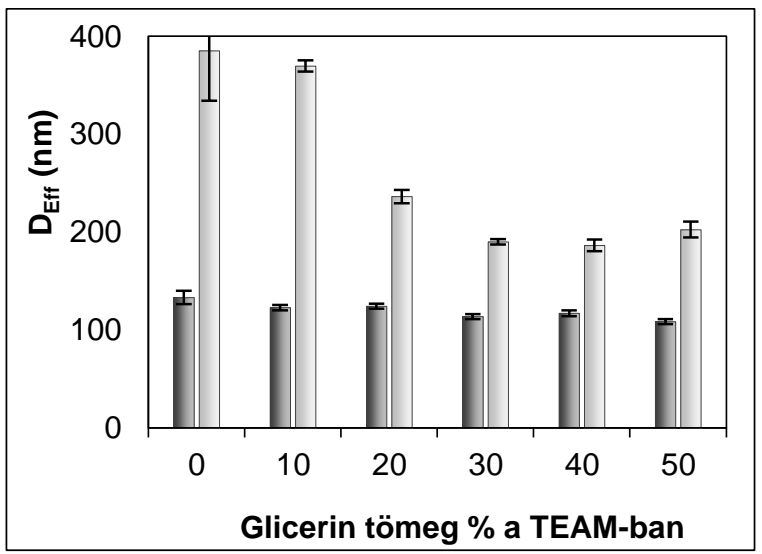

C

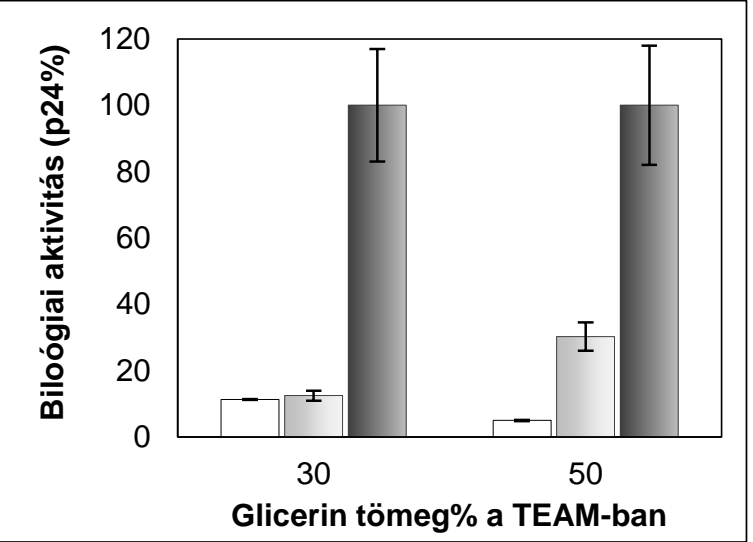

20. Ábra. A különböző glicerin-tartalmú DermaVirek A) biológiai aktivitása 1 hetes $-20^{\circ} \mathrm{C}$-os tárolás után $(\square)$ a glicerint nem tartalmazó TEAM-ban frissen formulált formulációhoz $(\square)$ képest $\left(\mathrm{y}=-0.1219 \mathrm{x}^{2}+\right.$ $7.1608 \mathrm{x}-51.149, \mathrm{R}^{2}=0.834$ ). B) részecskeméretek 1 hetes $-20^{\circ} \mathrm{C}$-os tárolás után ( $\square$ ) és a friss kontrollok (匹). C) Glicerin tartalmú formulációk stabilitás vizsgálata során mért relatív biológiai aktivitások $-20^{\circ} \mathrm{C}$-on $(\square)$ és $4{ }^{\circ} \mathrm{C}$-on $(\square)$ (viszonyítási alap mindkét formulációnál a friss kontroll $\square$ ). 
Azt tapasztaltuk, hogy a friss mintáknál a glicerin mennyiségének növekedésével csökken a biológiai aktivitás (20. Ábra, A). A tároltaknál azonban optimuma van a glicerintartalomnak 30 tömeg\%-nál ahol nem szignifikáns $(\mathrm{p}=0,48)$ a különbség a tárolt és a kontroll között. Azonban ez is csak 60\%-át éri el a glicerint nem tartalmazó frissen készített formuláció potenciájának. A részecskeméreteknél a 30 és a 40\%-os glicerintartalom mellett kaptuk vissza leginkább a kiindulási értékeket (20. Ábra, B), bár a glicerint nem tartalmazó és 10\%-os glicerines kivételével minden minta elfogadási kritériumon belül volt $(70-300 \mathrm{~nm})$. A kapott eredményt azzal magyarázhatjuk, hogy valószínűleg a glicerin citotoxikus tulajdonsága sem elhanyagolható (erre enged következtetni az is, hogy a növekvő glicerin mennyiséggel csökken a mérhető génexpresszió). A fenti biológiai aktivitás vizsgálatot 96 lyukú lemezen végeztük, ahol a sejtek száma alacsony (30000 sejt/lyuk), a további kísérleteket 48 lyukú lemezen végeztük, ahol egy lyukban 200000 sejt van, így a citotoxikus tulajdonság kisebb mértékben avatkozhat az eredménybe. Itt már csak a 30 és az 50\%-os glicerines TEAM-ot használtuk, és 4 hetes $-20^{\circ} \mathrm{C}$-os, illetve $4^{\circ} \mathrm{C}$-os tarolást indítottunk. A kísérletből kiderült, hogy a glicerin nem képes hosszú távon megőrizni a DermaVir stabilitását a fagyasztott folyadék formulációban egyik hőmérsékleten sem (20. Ábra, C). A glicerint nem tartalmazó kontrollt ismét nem közelítették meg a glicerines minták, a sejtek nagyobb számának ellenére, ami arra enged következtetni, hogy nem csupán a glicerin citotoxikus tulajdonsága okozza a problémát.

Hasonló eredményeket kaptunk a liofilizált glicerines formulációval is: a visszaoldás problémája bár megoldódott, de a biológiai aktivitás nem volt képes utolérni a glicerint nem tartalmazót, illetve a saját frissen készített kontrollját (17. Táblázat).

17. Táblázat. A TEAM-mal, illetve a $30 \%$ és $50 \%$ glicerint is tartalmazó TEAM-mal készített DermaVir-ek vizsgálata liofilizálás után. A biológiai aktivitásoknál a viszonyítási alap minden formulációnál a frissen készített kontroll.

\begin{tabular}{ccccccc}
\hline & $\begin{array}{c}\text { A260 liof } \\
\text { előtt }\end{array}$ & $\begin{array}{c}\text { A260 liof } \\
\text { után }\end{array}$ & $\begin{array}{c}\mathbf{D}_{\text {Eff }} \text { liof előtt } \\
(\mathbf{n m})\end{array}$ & $\begin{array}{c}\mathbf{D}_{\text {Eff liof után }} \\
(\mathbf{n m})\end{array}$ & $\mathbf{4}^{\circ} \mathbf{C}, \mathbf{4}$ hét után & $\mathbf{- 2 0}^{\circ} \mathbf{C}, \mathbf{4}$ hét után \\
\hline TEAM & 0,7221 & 0,0226 & $181 \pm 6$ & $484 \pm 174$ & $2 \pm 1$ & $1 \pm 1$ \\
TEAM + 30\% & 0,8379 & 0,7909 & $135 \pm 5$ & $234 \pm 5$ & $19 \pm 9$ & $11 \pm 1$ \\
\hline
\end{tabular}




\begin{tabular}{|c|c|c|c|c|c|c|}
\hline glicerin & & & & & & \\
\hline $\begin{array}{c}\text { TEAM + 50\% } \\
\text { glicerin }\end{array}$ & 0,7980 & 0,7539 & $121 \pm 35$ & $183 \pm 7$ & $4 \pm 1$ & $8 \pm 6$ \\
\hline
\end{tabular}

Annak ellenére, hogy a glicerintartalmú liofilizált formuláció egyelőre elmarad a várt biológiai aktivitástól és stabilitástól, tovább vizsgáljuk a jövőben, mint lehetséges liofilizált formulációt.

A glicerintartalmú formulációk esetében fontos megemlíteni, hogy minden kísérletben nagyon magas abszorbancia-maximumot mutatnak. A DermaVir nanorészecskére jellemző, hogy a komponensek abszorbancia-összegéhez képest magasabb értéket mérünk, tehát hiperkromofória jelenik meg az UV-spektrumon, amikor a részecskét vizsgáljuk. A fenti kísérletekben a kontroll TEAM-tartalmú formulációhoz képest mindig magasabb hiperkromofória értékeket kaptunk a glicerines formulációkra, annak ellenére, hogy a pDNS koncentráció ugyanakkora minden esetben (18. Táblázat). Ennek jelentőségével a későbbiekben a DermaVir nanorészecske szerkezetének vizsgálata fejezetben foglalkozunk.

18. Táblázat. A TEAM-mal, illetve a 30\% és 50\% glicerint is tartalmazó TEAM-mal készített DermaVir-ek hiperkromofóriái.

\begin{tabular}{cc}
\hline Formuláció & Hiperkromofória $(\boldsymbol{\%}) *$ \\
\hline TEAM & 26,0 \\
TEAM+30\% glicerin & 59,8 \\
TEAM+50\% glicerin & 60,8 \\
\hline
\end{tabular}

*A nanorészecske 260 nm-en mért abszorbanciájának emelkedése a komponensek azonos koncentrációban 260 nm-en mért abszorbancia-összegéhez képest százalékos formában.

\section{$\underline{\text { A kétfiolás fagyasztott formuláció }}$}

Miután a glükóz összeférhetetlensége a PEIm-mel megoldódott azzal, hogy azt TEAM pufferre cseréltük, megtehettük, hogy a korábbi háromról kettőre csökkentjük az 
összekeverendő oldatok számát. Elképzelésünk szerint kétfiolás formulációt készítünk, melyben a pDNS és a PEIm külön fiolában van tárolva $-20^{\circ} \mathrm{C}-o s$ fagyasztóban, majd a kezelés elött kiolvasztva egyszerüen össze kell keverni őket, és kész a DermaVir nanomedicína. Elindítottunk egy hosszú távú stabilitás vizsgálatot, ahol a 19. Táblázatban részletezett formulációkat vizsgáltuk.

19. Táblázat. A stabilitás vizsgálatban tárolásra letett formulációk komponenseinek összetétele.

\begin{tabular}{cccc}
\hline Formuláció & pDNS komponens & PEIm komponens & $\begin{array}{c}\text { Komponensek térfogat } \\
\text { aránya }\left(\mathbf{V}_{\mathbf{p D N S}}: \mathbf{V}_{\text {PEIm }}\right)\end{array}$ \\
\hline F1 & pDNS + 3 rész TEAM & PEIm + 3 rész TEAM & $1: 1$ \\
F2 & pDNS + 6 rész TEAM & PEIm oldat & $7: 1$ \\
F3 & pDNS + 3 rész MilliQ víz & PEIm + 3 rész 2TEA2M* & $1: 1$ \\
& pDNS oldat & PEIm + 6 rész TEAM & $1: 7$ \\
\hline
\end{tabular}

*2TEA2M: 20\% mannitol tartalmú 20 mM TEA puffer, $\mathrm{pH}=7,6$.

A tárolás hőmérsékletének a $-20^{\circ} \mathrm{C}$-ot választottuk, mivel korábbi eredményeink alapján a pDNS $-20^{\circ} \mathrm{C}$-on megörzi stabilitását évekig, hasonlóan, mint $-80^{\circ} \mathrm{C}$-on. A formulációk tehát mindannyian ugyanazt a végösszetételt eredményezik az összekeverés után: az új formulációt. A tesztelési pontok 1, 6, 9 és 12 hónapi tárolásnál voltak. A biológiai aktivitás változását a tárolás során a különböző formulációknál a 21 . Ábra mutatja. Viszonyítási alap minden időpontban a frissen készített kontroll. Legstabilabb formulációnak az F2 bizonyult (21. Ábra, B), vagyis az a verzió, amikor mind a 6 rész TEAM puffer a pDNS mellett van, a PEIm pedig önmagában. Ez a formuláció a stabilitás program alatt végig hibahatáron belül megegyező eredményt produkált a frissen készített kontroll mintákkal. Az F1, vagyis a 3-3 rész puffert tartalmazó formuláció ugyan nem sokkal, de elmarad ettől az eredménytől, a 12. hónapra csupán a friss kontroll 74\%-át érte el. Az F3 formulációval kapcsolatban nem csak az a probléma merült fel, hogy már 1 hónap után csak $81 \%$-os potenciát mutat, hanem mivel a PEIm mellett van az összes szükséges mannitol, így a 15\%-os mannitol oldatot kellett fagyasztani, amiből a hütés 
folyamán a cukoralkohol kikristályosodását figyeltük meg, ami a kiolvasztás utáni hosszas vortexelés hatására sem oldódott vissza teljesen.

A

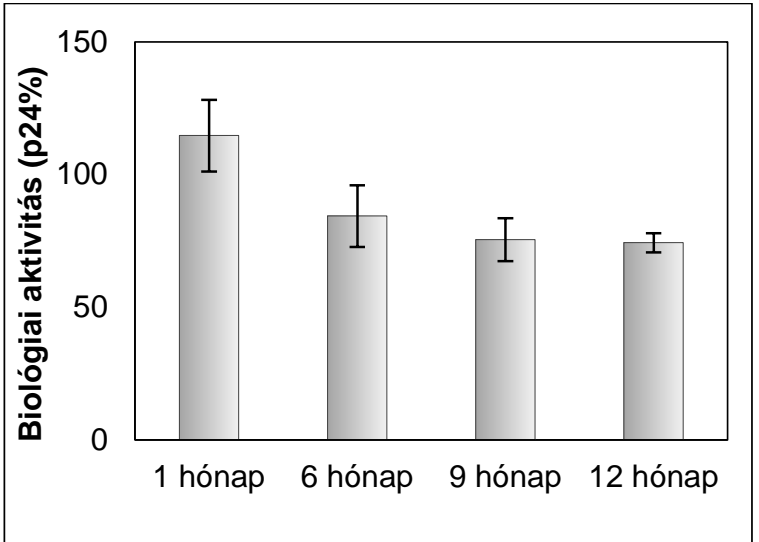

$\mathrm{C}$

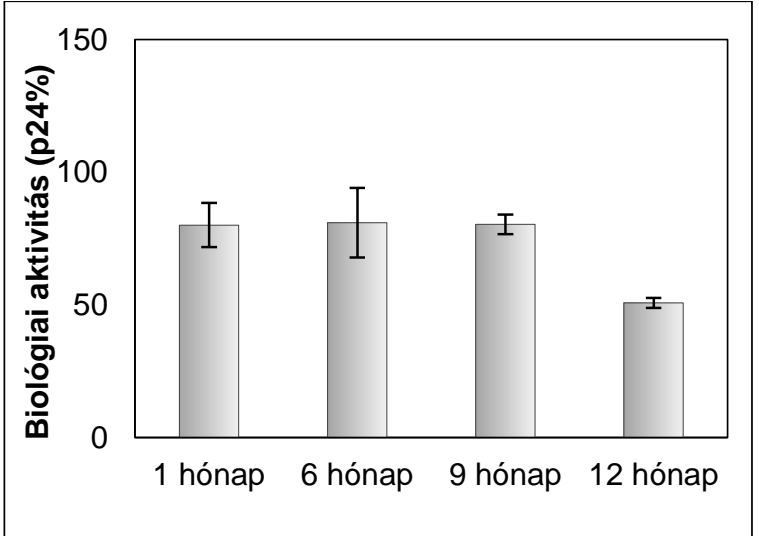

B

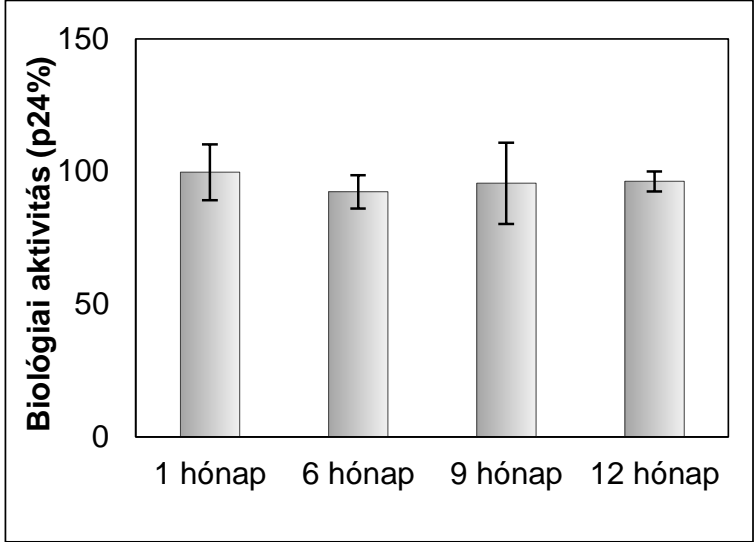

$\mathrm{D}$

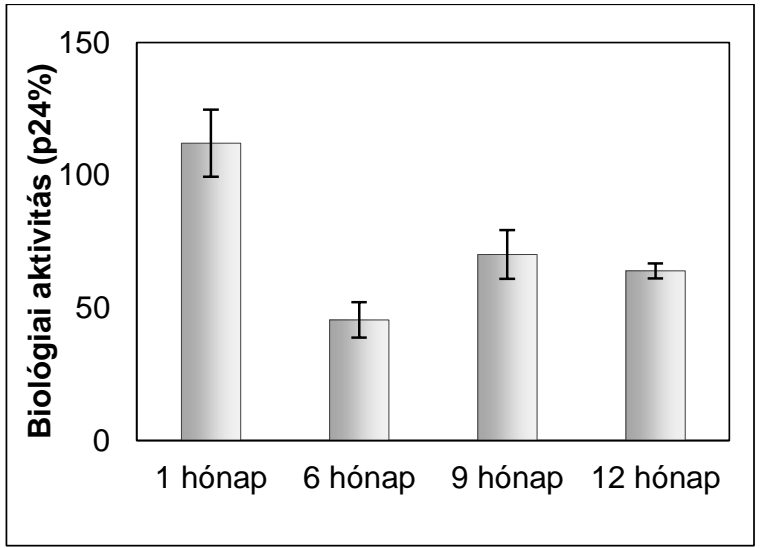

21. Ábra. A kétfiolás fagyasztott formulációk stabilitás vizsgálata során mért relatív biológiai aktivitások a mindenkori friss kontrollhoz képest A) F1: pDNS3xTEAM+PEIm3xTEAM, B) F2: pDNS6xTEAM+PEIm, C) F3: pDNS3xMQ+PEIm3x2TEA2M, D) F4: pDNS+PEIm6xTEAM.

Annak érdekében, hogy biztosak lehessünk a termék stabilitásában, az F2 kompozíciót választottuk, a következő klinikai vizsgálatban ezt fogjuk használni. Ez a formuláció mutatott egyedül 100\%-os biológiai aktivitást a stabilitás vizsgálatban a friss kontrollhoz képest minden mért időpontban. Ezt a formulációt az eddigi kritikus $-80^{\circ} \mathrm{C}$ helyett $-20^{\circ} \mathrm{C}$-on lehet tárolni, ami nagyban megemeli azon klinikák és egészségügyi 
intézmények számát, melyek képesek lesznek tárolni a készítményt. A komponensek számának lecsökkentése pedig lehetővé teszi, hogy ne csak klinikai gyógyszerész, hanem a nővér is elkészíthesse a nanomedicínát. Elképzelésünk szerint a legpraktikusabb kiszerelés az lenne, ha a TEAM pufferrel hígított pDNS üvegfiolába, míg a PEIm elöre töltött fecskendőben lenne letöltve (22. Ábra). A polimer oldat fiolába való fecskendezésével egyszerüen elkészíthető lenne a nanomedicína szuszpenzió.

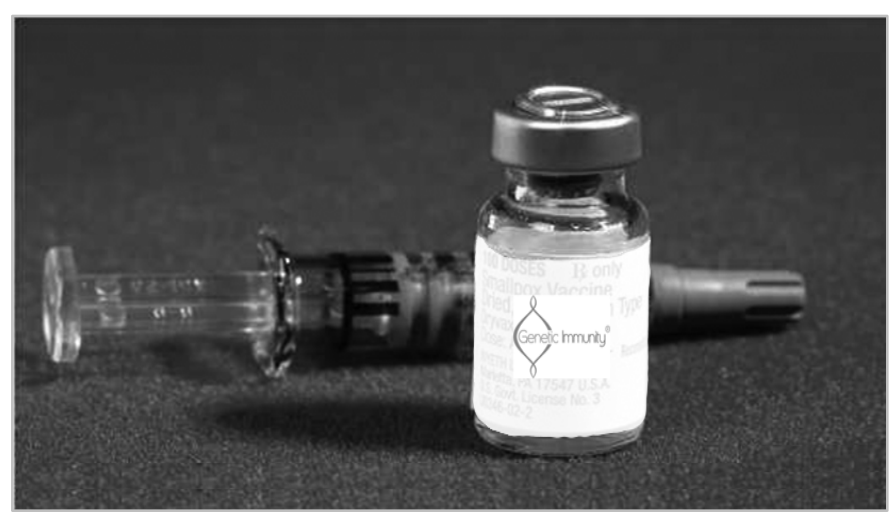

22. Ábra. A kétfiolás fagyasztott formulációk tervezett kiszerelése.

A termék engedélyeztetése sok kihívással jár, miután a polimerbe kondenzált pDNS precedens nélküli a gyógyászatban, de maga a kétfiolás forma már elfogadott, például a mell- illetve a prosztata rák gyógyítására szolgáló kemoterápiás szereknél. ${ }^{116,117}$ 


\subsection{A DermaVir nanorészecske szerkezetének vizsgálata}

\subsubsection{A részecske kialakulásának nyomon követése}

A DermaVir nanomedicína esetében, a hagyományos gyógyszerekkel, a kis molekulákkal ellentétben, az analitikai módszerek tárháza jóval kisebb. Olyan egzakt eredményt szolgáltató módszer, mint például a szerkezetazonosításra használt NMR, HPLC és hasonló nagymüszeres módszerek az ilyen összetett rendszereknél nem alkalmazhatók. Tény, hogy a legtöbb információt adó teszt a biológiai aktivitás vizsgálat, azonban a formuláció jobbá, stabilabbá tételének az a feltétele, hogy kiderítsük, a különböző formulációk között milyen (akár apró) különbségek okozzák a biológiai aktivitás (akár hatalmas) eltérését.

Eltekintve a nagymüszeres szerkezetazonosító módszerektől, azért a DermaVir nanorészecske kialakulása és a termék minősége, fizikokémiai tulajdonságai több módszerrel is vizsgálhatók. Ilyen például az általunk használt dinamikus fényszórás elvén alapuló (DLS) részecskeméret meghatározási módszer. Ez a módszer a nanorészecskék körében gyakran használt módja a részecskeméret meghatározásának, mivel gömbszerü részecskék esetén meglehetősen pontosan méri a hidrodinamikai átmérőt. ${ }^{118} \mathrm{Az}$ általunk használt analitikai módszer a nemzetközi International Conference on Harmonisation Q2(R1) ajánlása alapján validált: pontosságát, precizitását, reprodukálhatóságát és állóképességét ellenőriztük és bizonyítottuk, a készülék pedig a gyártói előírások szerint kvalifikált. Az, hogy a PEIm és a pDNS összekeverésével képesek vagyunk detektálni kompakt részecskét a DLS módszerrel, arra bizonyíték, hogy a polimer kondenzálja a plazmidot. A komponenseket ugyanis önmagukban nem tudjuk mérni, nem olyan tömör molekulák/gombolyagok külön-külön, hogy ezzel a módszerrel detektálhatóak legyenek. Ez tehát már önmagában bizonyíték a PEIm/pDNS részecske kialakulására, azonban ezt számos más, független módszerrel is alá tudjuk támasztani. Az egyik ilyen a neutralizációs gélelektroforézis, vagyis a retardációs gél. E standardizált módszer során a pDNS-t gyakorlatilag megtitráljuk a PEIm-mel, aminek hatására az fokozatosan kondenzálódik, ami a gélen úgy jelentkezik, hogy a pDNS egyre kevésbé képes migrálni a gélben, majd a teljes kondenzációtól kezdve a zsebben marad (23. Ábra, A). Ezért két tényező felelős: az egyik, hogy az addig negatív töltésű pDNS a „becsomagolódás” után a külső kationos buroknak köszönhetően pozitív felületü lesz, ami miatt nyilvánvalóan nem fog vándorolni 
a pozitív elektród felé, ahogy azt a csupasz pDNS anion teszi. Azonban ha a 23. Ábra, A) gélfotóját megfigyeljük, az is világosan látszik, hogy a másik irányba, a negatív elektród felé sem migrál a részecske. Ennek pedig az az oka, hogy kompakt nanorészecskék alakulnak ki, amelyek nem tudnak belépni a gél pórusaiba. A gélről az is leolvasható, hogy a pDNS a N/P=2 felett kondenzálódik maradéktalanul és marad a zsebben. Ezzel a töltéskiegyenlítődés/változással teljes összhangban van az a titrálási görbe, amit a fent leírt módon készített minták zeta potenciál mérésével kaptunk (23. Ábra, B). Itt ugyanis látszik, hogy a negatív plazmidból kiindulva a PEIm mennyiségének fokozatos növelésével hogyan kondenzálódik a pDNS és válik teljesen pozitívvá a nanorészecske. A titrálási görbe ekvivalencia pontja, vagyis jelen esetben az a pont, ahonnan a részecske egyértelmúen pozitív, ugyanúgy a N/P=2, összhangban a gél retardációs eredményekkel. A zeta potenciál a részecskeméret méréshez hasonlóan nagyon divatos módszer a nanomedicínák területén, bár nem egyértelmủ az irodalom álláspontja, hogy milyen érték is a kedvező biológiai aktivitás szempontjából. ${ }^{119}$ Az előjelet tekintve egyetértés van, mivel a negatív sejtmembránhoz való kötődés, illetve az azon való átjutás miatt pozitív felületü részecskékre van szükség, azonban nem lehetnek túl pozitívak, mert a túl nagy töltés toxikus lehet in vivo környezetben. ${ }^{47}$ Olyan zeta potenciál értéket, ami biztosítja a megfelelő célzást és bejutást, de biztonságot is szavatol, egyelöre nem állapítottak meg, bár ez nyilván több más tényezőtől is függ, nem kizárólag a felületi töltéstől. ${ }^{47,58}$ Annyi mindenesetre elmondható a DermaVir nanorészecskéről, hogy a gyengén pozitív részecskék közé tartozik. ${ }^{119}$ A fényszórásmérés, a gélelektroforézis és a zeta potenciál titrálás mellett a részecskék kialakulása UV-spektrofotometriásan is követhető. Ahogy már a glicerintartalmú formulációknál említésre került, pDNS kondenzálódása során, az UV spektrumon abszorbancia-emelkedést figyelhetünk meg (23. Ábra, C). Ez nem magyarázható a komponensek abszorbanciáinak összeadódásával, mivel a PEIm és a TEAM puffer spektruma alapvonal. A pDNS PEIm-mel való titrálása során a zeta potenciál eredményekhez hasonlóan UV méréssel követve is látszik a fokozatosság (23. Ábra, D), ahogy a polimer egyre inkább kondenzálja a pDNS-t, míg végül az abszorbancia állandó értéket mutat a teljes kondenzálódástól, a már előzőleg 2 módszerrel is igazolt $\mathrm{N} / \mathrm{P}=2$ aránytól felfelé. 
A

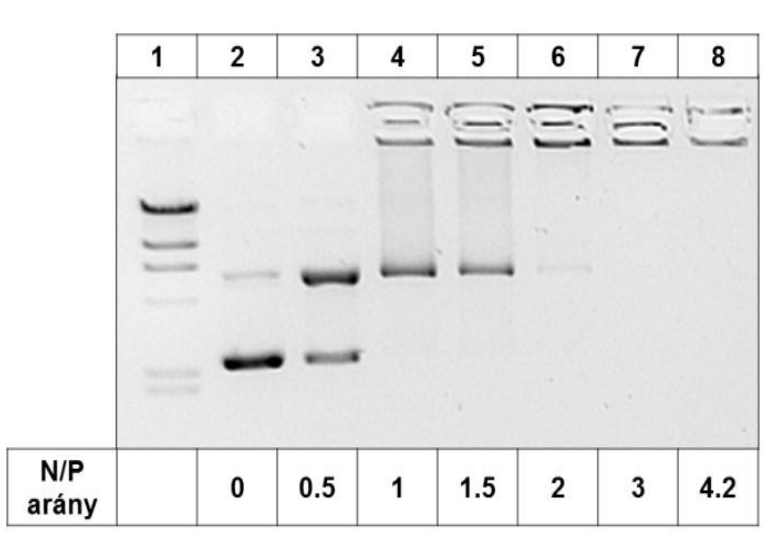

C

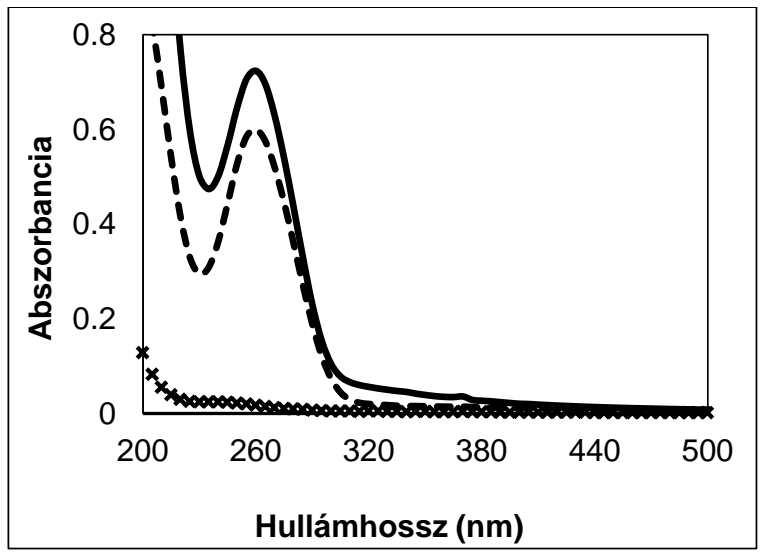

E

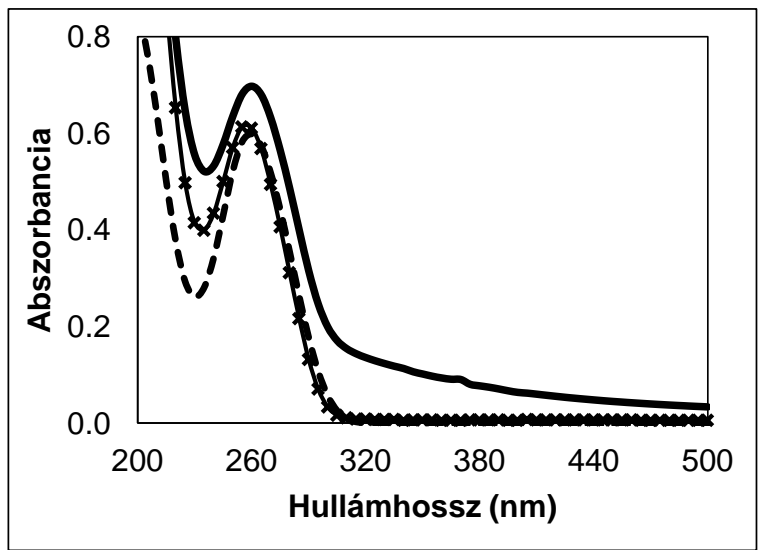

B

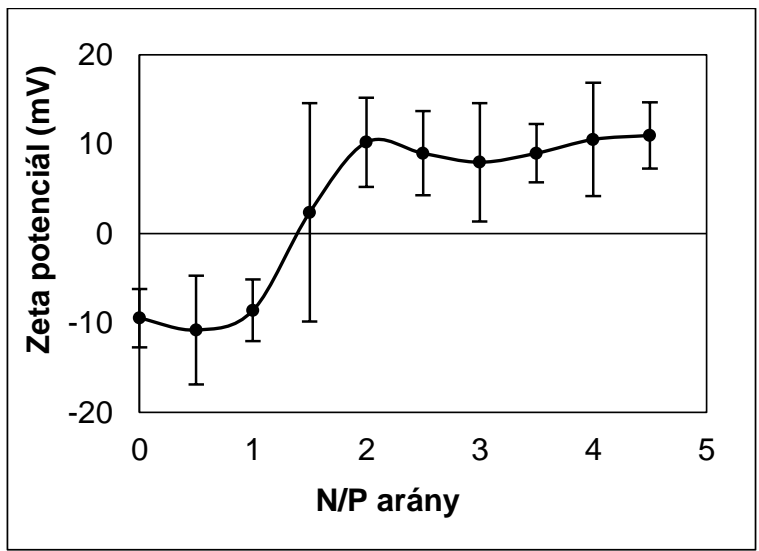

D

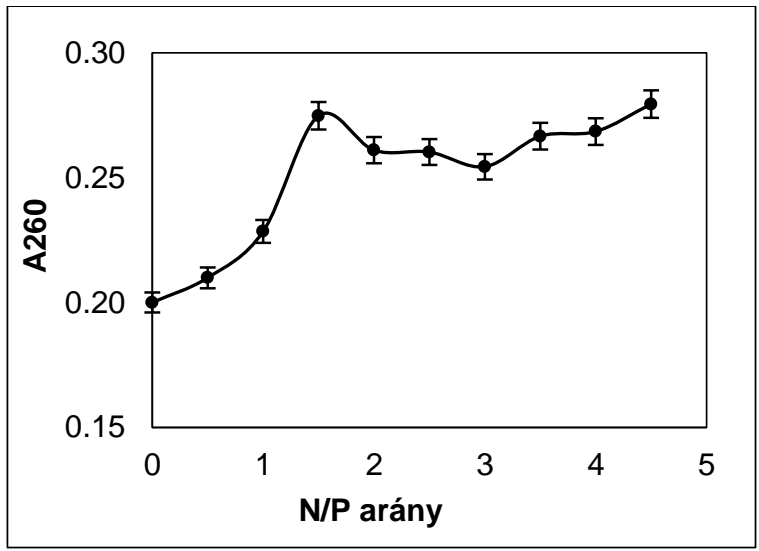

F

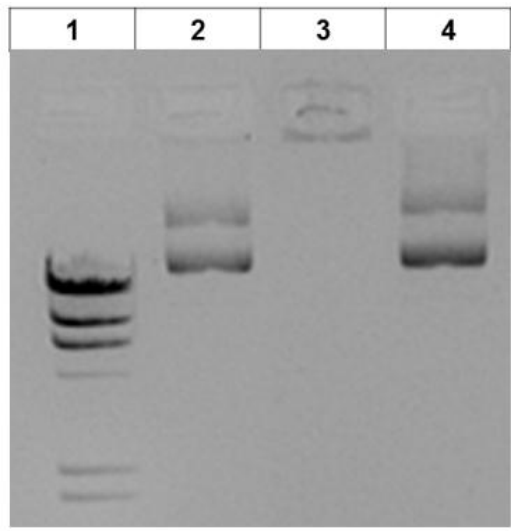

23. Ábra. A nanorészecske kialakulásának követése különböző módszerekkel. A) Neutralizációs gélelektroforézis eredménye. A N/P=0 arány a pDNS (pRED) kontrollnak felel meg. Az \#1 zsebben a molekulatömeg marker látható. B) A titrálás követése zeta potenciál méréssel. Az $\mathrm{N} / \mathrm{P}=0$ arány itt is a

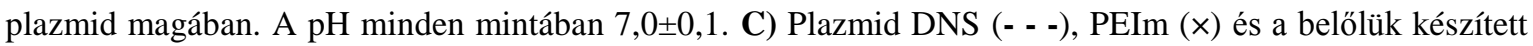
DermaVir nanorészecske (-) UV spektruma (pDNS koncentráció $30 \mu \mathrm{g} / \mathrm{ml}$ ). D) A titrálás követése UVspektrofotometriával (pDNS koncentráció $10 \mu \mathrm{g} / \mathrm{ml}$ ). E) A pDNS (- - -), a poliplex (-) és a dekomplexált poliplex (*) UV spektrumai (pDNS koncentráció $30 \mu \mathrm{g} / \mathrm{ml}$ ). F) A pDNS (\#2 zseb), a nanorészecske (\#3 
zseb) és a dekomplexált nanorészecske (\#4 zseb) gélelektroforézis felvétele. Az \#1 zsebben a molekulatömeg marker látható.

Ez az abszorbancia-emelkedés, vagyis hiperkromofória, azzal a szerkezetváltozással magyarázható, ami akkor lép fel, mikor a PEIm pDNS-hez való adagolása során a polimer kondenzálja, nanorészecskévé tömöríti azt. ${ }^{120}$ Ezt az elméletet alátámasztja, hogy ha a részecskét szétszedjük, dekomplexáljuk SDS segítségével, visszakapjuk az eredeti abszorbancia-értéket, vagyis a pDNS-ét (23. Ábra, E), illetve így a dekomplexált pDNS újra migrál a gélben (23. Ábra, F).

Már az új formuláció kifejlesztése során is megfigyeltük azt a jelenséget, hogy a DermaVir készítésekor kialakuló hiperkromofória nem állandó mértékü, hanem a különböző minőségü komponensek összekeverésével különböző mértékű abszorbanciaemelkedés mérhető. Reprodukálhatóan kisebb hiperkromofóriát mutat a jelenlegi klinikai (DV1), glükózos formuláció, mint az új (DV2), TEAM pufferes (24. Ábra, A).

A

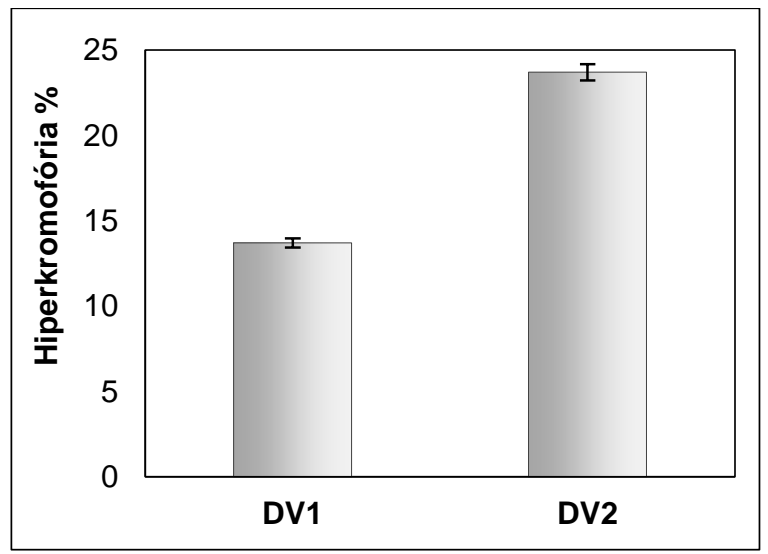

B

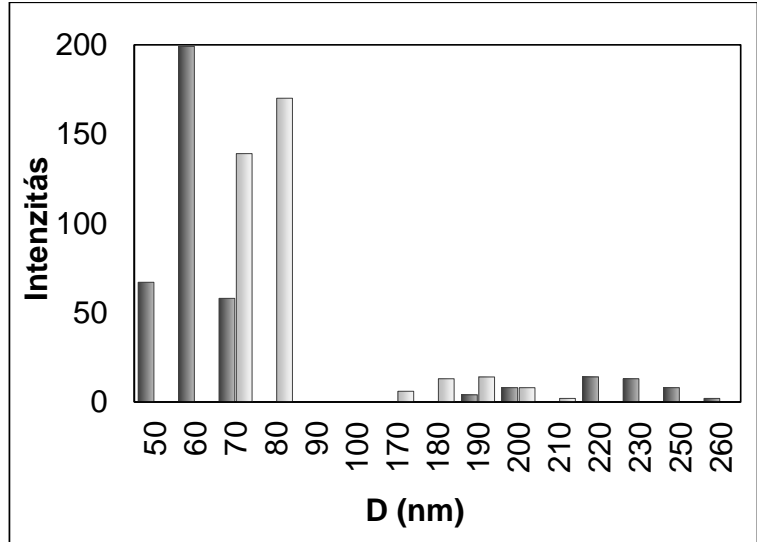

24. Ábra. A hiperkromofória vizsgálata. A) A jelenlegi klinikai (DV1) és az új formulációkra (DV2) számított hiperkromofóriák. B) A jelenlegi klinikai (DV1 @) és az új formulációkra (DV2 匹) mért részecskeméret eloszlás (DLS módszerrel). 
A hiperkromofóriát magyarázni lehetne akár azzal is, hogy a nanorészecskék kompakt, tömör jellege miatt megnövekszik a fényszórás az oldatban. ${ }^{121}$ Ennek azonban ellentmond az a tény, hogy mindkét formulációban hasonlók a mért részecskeméretetek (DV1: $130 \pm 7$ nm és DV2: $133 \pm 5 \mathrm{~nm}$ ), így ha a fényszórást a részecske maga okozná, a mért abszorbancia-emelkedés is (közel) egyforma kellene, hogy legyen. Nem csak az átlag részecskeméret, hanem emellett a két formuláció részecskéinek méreteloszlása is nagyon hasonló, ahogy azt már a különböző méretű plazmidokkal készített nanorészecskéknél is láttuk (10. Ábra, 24. Ábra, B). Mindkét formulációnál két viszonylag diszkrét mérettartományba eső részecskék vannak: egy kisebb régió 50-90 nm között és egy nagyobb 170-260 nm között.

\subsubsection{A DermaVir nanorészecske szerkezete}

Mivel azt már a fent leírtak szerint bizonyítottuk, hogy a hiperkromofória a részecske kialakulásakor létrejövő szerkezetváltozással van összefüggésben, különböző mértékének magyarázatát a két formuláció nanorészecskéinek finomszerkezete közötti eltérésekben kellett keresni. Mivel a különbség a két formuláció között föként a NaCl-tartalom, megvizsgáltuk annak hatását a hiperkromofóriára: az alacsony NaCl-tartalmú pDNS-t kiegészítettük 0,3 molekvivalensről 1-re; 3-ra; 6-ra és 10-re. Az eredmény azt mutatta, hogy fordított arányosság van a pDNS melletti nátrium-klorid koncentráció és az UVfotometriásan mérhető abszorbancia (így a számított hiperkromofória) között (25. Ábra, A). Amikor az új formuláció (DV2) alacsony NaCl-tartalmú pDNS-ét kiegészítettük a jelenlegi klinikai formuláció (DV1) pDNS-e mellett megtalálható $\mathrm{NaCl}$ mennyiségével, vagyis a 6 molekvivalenst, annak hiperkromofóriája is lecsökkent az erre a formulációra jellemző 13\%-ra. Az ionerősség mellett a másik fontos tényező a $\mathrm{pH}$. A pH nemcsak a formulációs oldószer miatt fontos, miután a DermaVir rendszer egy polisavból (pDNS) és egy polibázisból (PEIm) áll, a protonkoncentráció nagyon fontos szerepet játszik azok ionos jellegének alakulásában a közeg ionerőssége mellett. Elkészítettünk ismét egy sorozat TEAM oldatot pH 3 és 9 között. Mindegyikkel készítettünk DermaVirt ugyanazt a pDNS-t és PEIm-et használva, majd az elkészült mintáknak megmértük az abszorbanciáit és kiszámítottuk a hiperkromofóriáit. Azt találtuk, hogy a $\mathrm{pH}$ a hiperkromofóriával egyenesen arányos, a NaCl-dal ellentétben (25. Ábra, B). Ez az eredmény összhangban 
van a korábban is kapott eredményekkel: amikor a DV2 egyébként 7,5-es pH-ját 3-4 közöttire állítottuk, visszakaptuk a DV1-re mért 13\% körüli hiperkromofóriát.

A

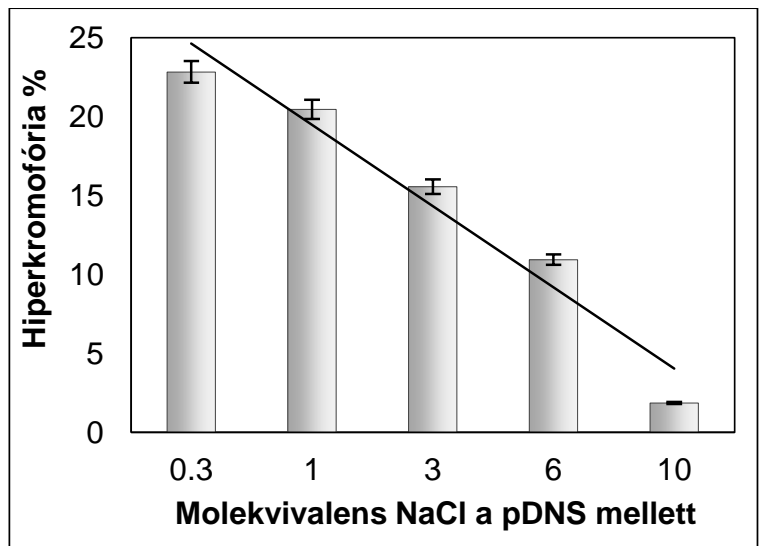

B

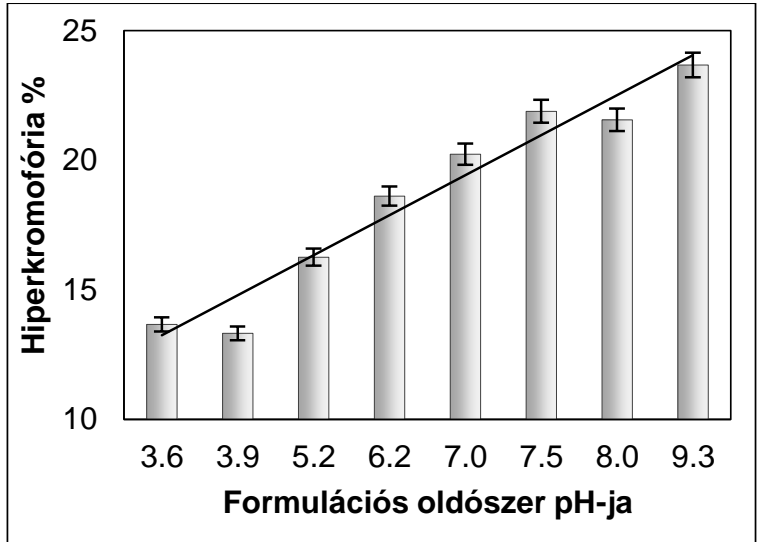

C

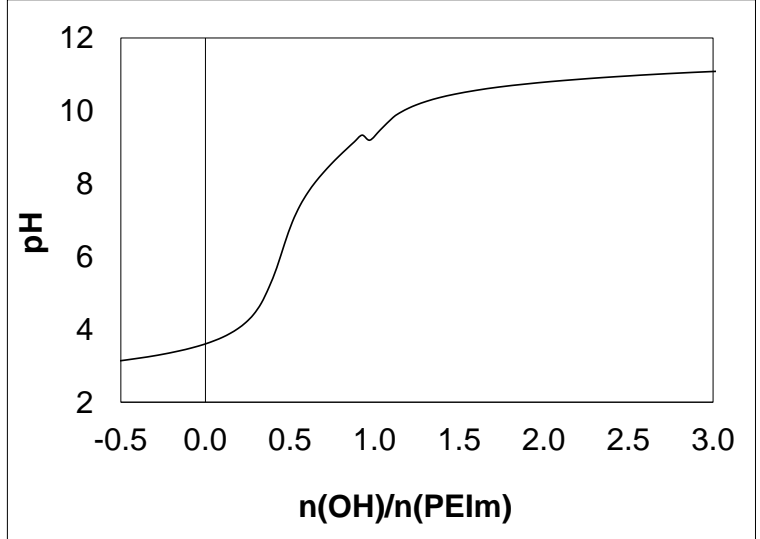

25. Ábra. A hiperkromofória vizsgálata. A) A DV2 és NaCl-dal kiegészített változatainak hiperkromofóriái $\left(y=-5,1448 \mathrm{x}+29,761 ; \mathrm{r}^{2}=0,95\right)$. A részecskeméretek rendre: $119 \pm 5 \mathrm{~nm} ; 118 \pm 2 \mathrm{~nm} ; 110 \pm 3 \mathrm{~nm} ; 109 \pm 4 \mathrm{~nm}$; $113 \pm 6 \mathrm{~nm}$. B) A pH és a hiperkromofória összefüggése $\left(\mathrm{y}=1,9403 \mathrm{x}+6,3354 ; \mathrm{r}^{2}=0,98\right)$. C) PEIm $\mathrm{pH}$ potenciometriás normált titrálási görbéje. A PSEQUAD programmal becsült pK érték 8,32 $\pm 0,002$. a 9-es pH felett látható törés a görbén a PEIm kezdődő kicsapódásának tulajdonítható.

Elméletünk szerint a jelenlegi klinikai, DV1 formulációban a magas protonáltsági fokú PEIm és a 6 molekvivalensnyi NaCl-ot tartalmazó pDNS oldatnál kevesebb kötés jöhet létre a pDNS és a PEIm között, mivel a pDNS foszfátjainak nagy része nátrium só 
formájában van jelen. Bár a mellette lévő PEIm 90\%-ban protonált, tehát erősen pozitív töltésü, a nátrium erősebb kation, mint a polimer $-\mathrm{NH}_{2}{ }^{+}$csoportja, így a pDNS-t körülvevő nátriumionokat nem tudja kihelyettesíteni, vagyis egy sokkal lazább szerkezetü nanorészecske jön létre, mint a DV2 formulációnál, ahol a nátrium hiánya miatt nem kell ilyen gátló tényezőkkel megküzdenie. Tehát a hiperkromofóriát a pDNS és a PEIm között kialakuló kötések indikátoraként értelmezzük, vagyis mértékét a kialakuló kötések száma határozza meg. Ugyanígy, alacsony pH-n a pDNS, mint gyenge sav, deprotonálódása meglehetősen visszaszorul, kevés a negatív töltése, így hiába protonált a PEIm nagyobb mértékben, kevés kötés fog kialakulni a komponensek között, így alacsonyabb lesz a hiperkromofória. Ahogy a pH növekszik, nő a pDNS deprotonáltsága és egyre több ionos kötést tud kialakítani, annak ellenére, hogy a PEIm kationos jellege csökken a hidroxidion koncentráció emelkedésével. Nem szabad azonban megfeledkezni arról, hogy a PEIm nitrogénjei négyszeres moláris feleslegben vannak a pDNS foszfátjaihoz képest, így akkor is marad elegendő ionos nitrogén a kötések létrehozásához, ha nő a pH. Emellett a PEIm potenciometriás titrálása során kiderült, hogy annak közelítő pK-ja 8,3 körüli érték (25. Ábra, C), tehát az általunk vizsgált $\mathrm{pH}$-tartományban a négyszeres feleslegben jelenlévő polimer pozitív töltéseinek száma mindenképp nagyobb kell, hogy legyen, mint a plazmid negatív töltéseinek száma. Ezzel az eredménnyel újabb bizonyosságot nyert a pH fontossága a formulációban a stabil szerkezet kialakulása szempontjából, ami a korábbi biológiai aktivitásbeli különbségeket is magyarázhatja. Arra is fény derült, hogy bár a PEIm ionos tulajdonságai is fontosak, mégis elsősorban a pDNS paraméterei határozzák meg a kialakuló részecske tulajdonságait. Emellett azt sem szabad figyelmen kívül hagynunk, hogy a fenti kísérletekben a pH-hiperkromofória kapcsolat vizsgálatakor az ionerősséget tartottuk állandó értéken a mintákban, a $\mathrm{NaCl}$ koncentráció-hiperkromofória viszonyának vizsgálatánál pedig a pH volt állandó, bár nyilván ezek együttesen határozzák meg a kialakuló nanorészecskék szerkezetét.

A $\mathrm{NaCl}$ hatásának fenti elméletét a hiperkromofóriára gél-retardációs vizsgálattal támasztottuk alá. 0,3 illetve 3 molekvivalensnyi NaCl-ot tartalmazó pDNS-t titráltuk PEIm-mel. Mivel a teljes kondenzálódás 1,5 és 2-es N/P arány közé esik, „nagy felbontású” vizsgálatot végeztünk: 1,6-2,0 N/P arányig készítettük a mintákat 0,2-enként (26. Ábra). Az eredmény alátámasztotta a teóriánkat, a 3 molekvivalensnyi NaCl-ot tartalmazó pDNS szemmel láthatóan nagyobb mennyiségű polimert igényel a teljes 
kondenzációhoz, mint a 0,3-szeres NaCl-ot tartalmazó pDNS. A 3 molekvivalens NaCltartalmú pDNS-nél még 1,8-as N/P aránynál is látszik szabadon migráló pDNS, míg a 0,3 molekvivalens NaCl-ot tartalmazó pDNS ekkor már teljesen kondenzált, nincs szabad pDNS a mintában.

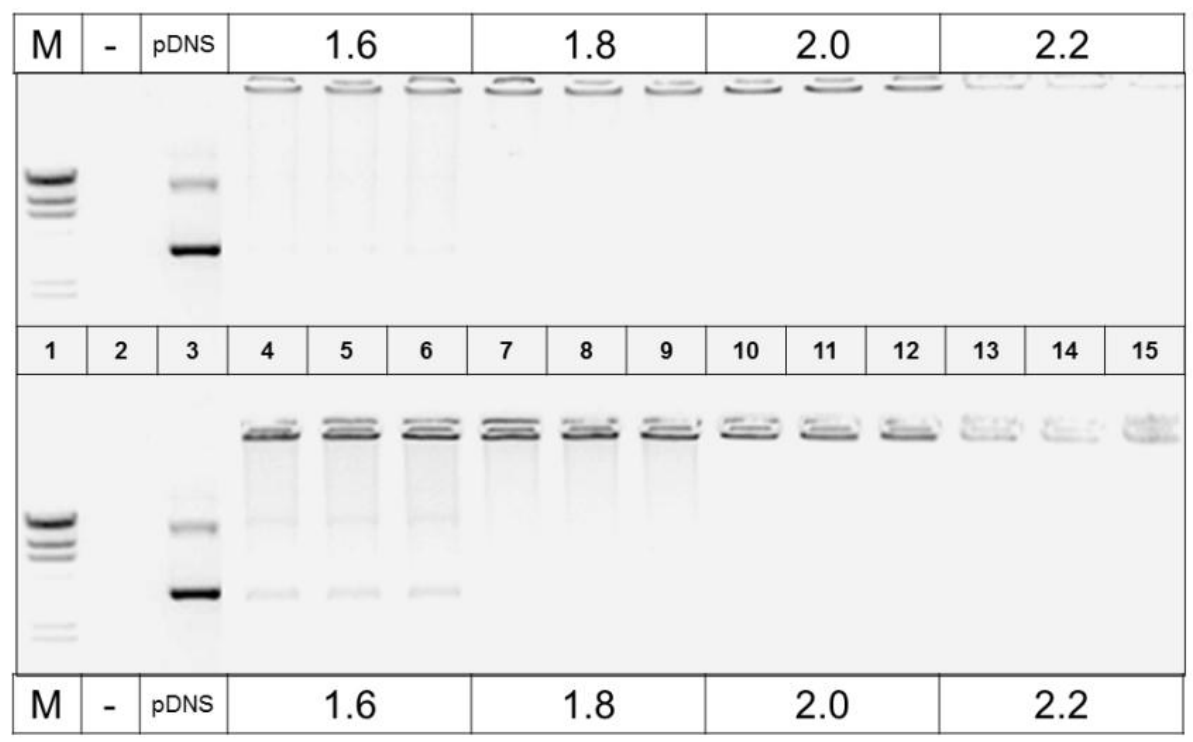

26. Ábra. A 0,3 molekvivalensnyi NaCl-ot tartalmazó pDNS (felső sor) és a 3 molekvivalensnyi NaCl-ot tartalmazó pDNS (alsó sor) titrálása ugyanazzal a PEIm-mel ugyanabban a TEAM pufferben. Zsebek: 1marker; 2-üres; 3-kontroll pDNS; 4-6-N/P=1,6; 7-9-N/P=1,8; 10-11-N/P=2,0; 13-15-N/P=2,2.

Az, hogy a hiperkromofória a komponensek asszociációjának mértékét mutatja bizonyítást nyert egy független módszerrel. Azonban az agaróz gélelektroforézis nem tartozik azon érzékeny módszerek közé, melyeket alkalmasak lennének szerkezeti különbségek egyértelmủ kimutatására. További bizonyítékot akartunk tehát a fentiekre, így a jelenlegi klinikai és az új formulációt összehasonlítottunk atomerő mikroszkópos kifinomult képalkotó módszerrel (27. Ábra). Ezzel a mikroszkóp-technikával bár a tárgylemezen rögzített részecskéket lehet vizsgálni, nem az oldatban közvetlenül, azonban mégis ez az irodalomban leginkább használt képalkotó módszer a poliplexek szerkezetének tanulmányozására. Az eredmény meglepően kézzelfogható igazolását adta korábbi eredményeinknek, a két formuláció eltérő kompaktsága egyértelmüen láthatóvá vált. Elsőként magáról a pDNS-ről készítettünk felvételeket, amelyen szépen látszik annak 
fonalas szerkezete (27. Ábra, A). A részecskék vizsgálata során bár a részecskeméret és az eloszlás a két formulációnál (a DLS mérésekhez hasonlóan) összemérhető, azok szerkezete merőben eltérőnek mutatkozott.

A

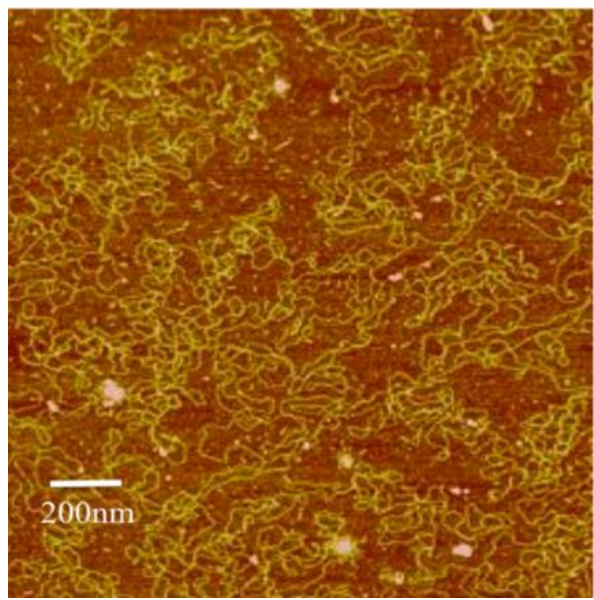

$\mathrm{C}$

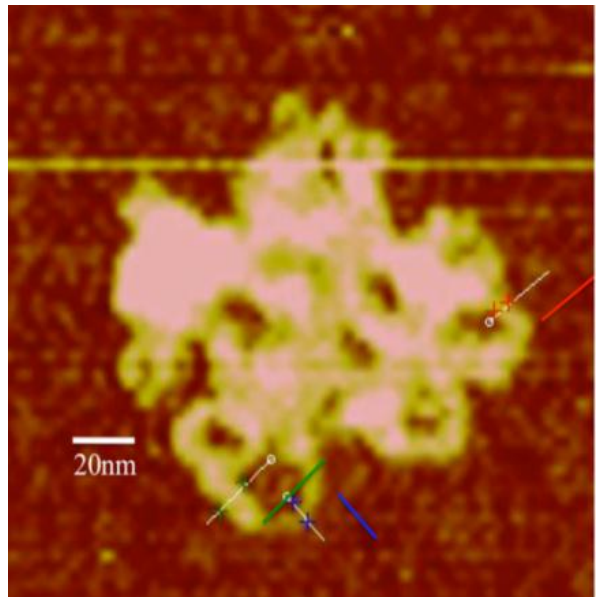

$\mathrm{B}$

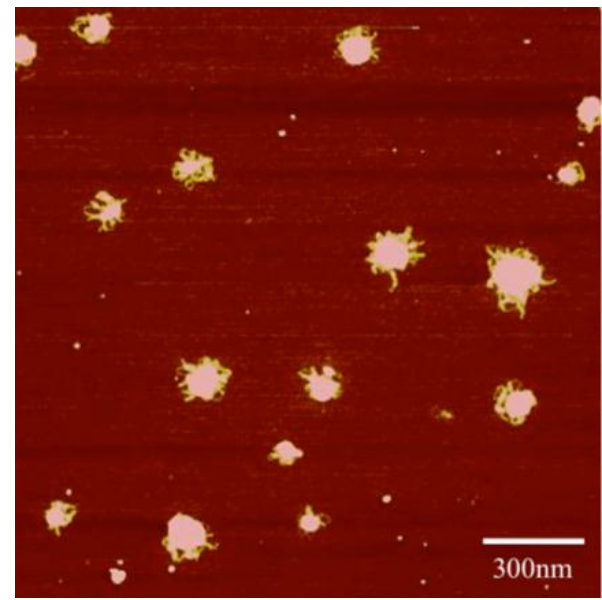

D

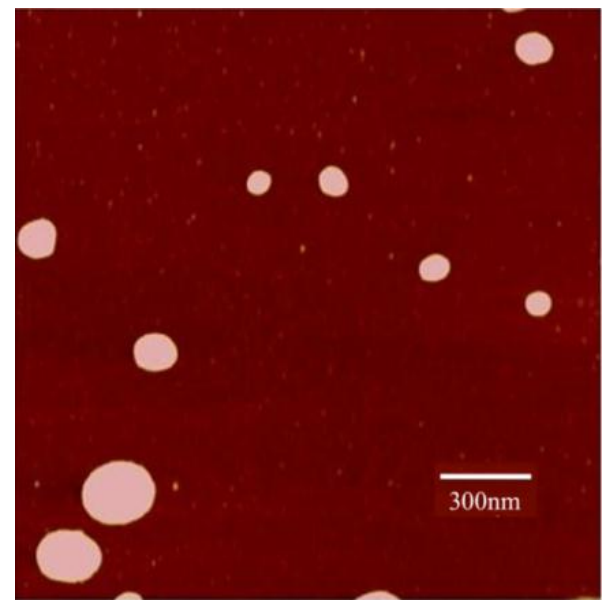

27. Ábra. pDNS és a két formuláció nanorészecskéinek AFM felvételei. A) pDNS önmagában. B) DV1 (jelenlegi klinikai) formuláció. C) DV1 részecske felnagyított képe. D) DV2 (új) formuláció.

A DV1 formuláció vizsgálatánál sok olyan részecskét találhatunk, melyeknél látható a pDNS kitüremkedése a poliplexből (27. Ábra B és C). Ezzel ellentétben a DV2 (új) formuláció szabályos gömb alakú, kompakt nanorészecskéket alkot, ahol a polimer burok teljes, zárt „kérget” alkot a pDNS körül. Ez az eredmény egyértelmüen alátámasztja azon 
elméletünket, miszerint a hiperkromofória a komponensek közötti asszociáció mértékének mutatója.

Ezután azt tanulmányoztuk, hogy a tárolási kísérletek során tapasztalt stabilitási különbségek a két formuláció között nyomon követhetők-e egyszerü UV méréssel (a hiperkromofória változásának követésével). Azt már az előzetes stabilitás vizsgálatok és AFM eredmények is bizonyították, hogy a DV2, vagyis az új formuláció sokkal stabilabb rendszer, de a hiperkromofória, vagyis a szerkezet szempontjából eddig még nem vizsgáltuk a poliplexek stabilitását. Készítettünk tehát egy olyan kísérleti tervet, melyben három hömérsékleten: $4^{\circ} \mathrm{C}, 25^{\circ} \mathrm{C}$ és $37^{\circ} \mathrm{C}$-on vizsgáltuk a két formuláció hiperkromofóriáinak alakulását tárolás során meghatározott időközönként (28. Ábra).

A

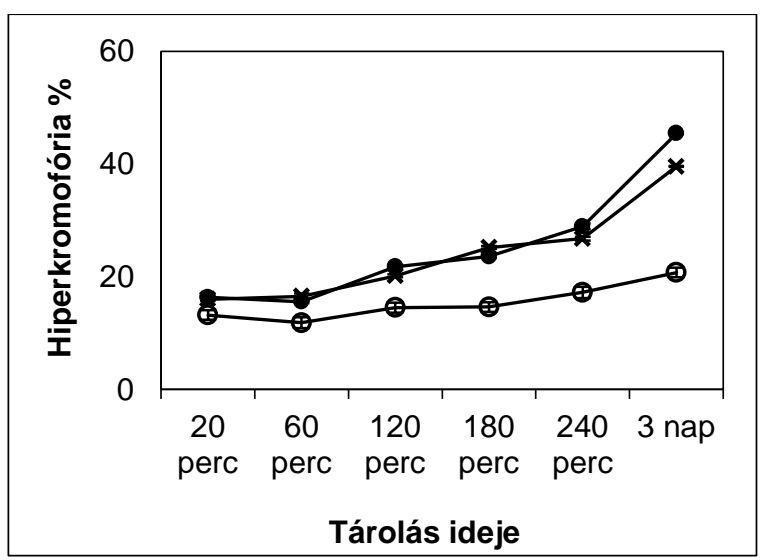

B

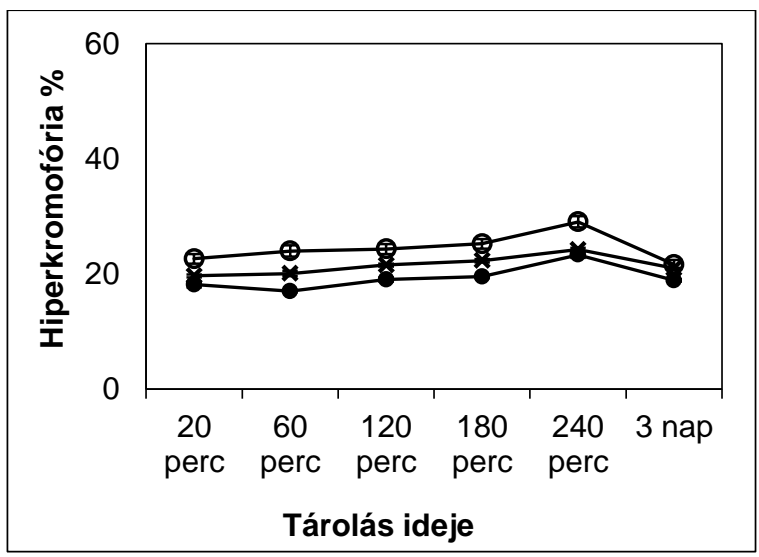

$\mathrm{C}$

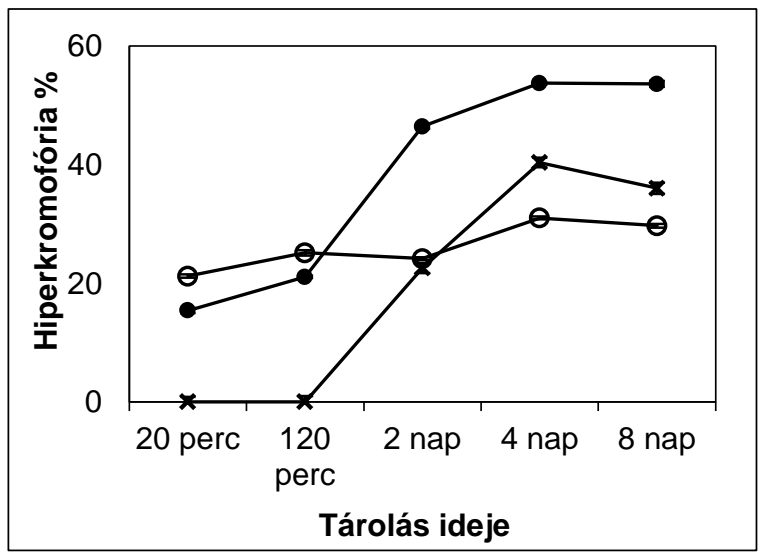


28. Ábra. A DV1 (jelenlegi klinikai) és a DV2 (új) formulációk hiperkromofóriájának változása. A) A DV1 hiperkromofóriája emelkedő trendet mutat $4^{\circ} \mathrm{C}$-on $(\mathrm{O})$, szobahőmérsékleten $(\times)$ és $37^{\circ} \mathrm{C}$-on (o) is. B) DV2 formuláció hiperkromofóriája kis fluktuációtól eltekintve állandó $4^{\circ} \mathrm{C}$-on $(\circ)$, szobahőmérsékleten $(\mathrm{x})$ és $37^{\circ} \mathrm{C}$-on (•) is. C) A DV1 (jelenlegi klinikai •) és a DV2 (új o) formulációk valamint a kontroll pDNS (x) hiperkromofóriájának változása $37^{\circ} \mathrm{C}$-on 8 nap alatt.

A három, illetve nyolc napos kísérletben azt láttuk, hogy a DV1 (klinikai) formuláció hiperkromofóriája nőtt a tárolás során mindhárom vizsgált hőmérsékleten (28. Ábra, A), míg a DV2 (új) formulációé állandó maradt (28. Ábra, B). A hiperkromofória növekedése ebben az esetben nem a komponensek szorosabb asszociációját jelenti, hanem a szabad, védelem nélküli pDNS egyfajta degradációjának indikátora. A DNS szálai ugyanis magasabb hőmérsékleten szétválnak (a pDNS denaturálódik), ami az abszorbancia növekedésével jár. ${ }^{122,123}$ Ezt bizonyítja a kontroll, „becsomagolatlan” pDNS-nél mért abszorbancia-növekedés a tárolás során (28. Ábra, C). A DV2 formuláció abszorbanciája 8 nap alatt $37^{\circ} \mathrm{C}$-on nem változik, amit az AFM-mel mért eredményekkel könnyen magyarázhatunk: a kompakt, tömör polimer burokkal rendelkező nanorészecske védelmet biztosít a pDNS számára belül. Azonban a DV1 részecskékben a pDNS néhol kitüremkedik a poliplexböl, vagyis a védelem nem teljes, a pDNS degradálódik magasabb hőmérsékleten csakúgy, mint a kontroll, amelyik nem volt nanorészecskévé „csomagolva”.

A DV1 és DV2 szerkezet- és stabilitás különbségének okát tehát tisztáztuk. Mind az ionerősség, mind a komponensek ionos jellege és a pH-hiperkromofória összefüggés magyarázza, hogy mért mérünk kisebb biológiai aktivitást a DV1 formulációra, mint a DV2-re (29. Ábra, A). Utolsó bizonyítékként pedig a DV2 formuláció előnyösebb szerkezetére és nagyobb stabilitására elvégeztünk egy kísérletet, melyben a két formulációt aspecifikus endonukleáz enzimmel inkubáltuk, majd leállítottuk az enzimreakciót EDTA hozzáadásával, végül dekomplexálás után megvizsgáltuk a részecskékben lévő pDNS-eket agaróz gélen (29. Ábra, B). Ebben a kísérletben gyakorlatilag az in vivo környezetet modelleztük, ahol szintén számos enzimatikus reakcióban degradálódhat a részecske. Az eredmény ismét megerősítette korábbi eredményeinket: a DV1-ben olyan nagymértékü károsodás érte a pDNS-t, hogy dekomplexálódás után csupán nagyon kevés pDNS-t lehetett detektálni a gélen, míg a DV2 esetében szemmel láthatólag sokkal több pDNS örződött meg. Ez logikus eredmény, ha meggondoljuk, hogy az AFM felvételeknél is 
látszott a kitüremkedő pDNS szálak sokasága a DV1 részecskéknél, míg a DV2 kompakt falán sokkal nehezebb áthatolni az enzimnek.

A

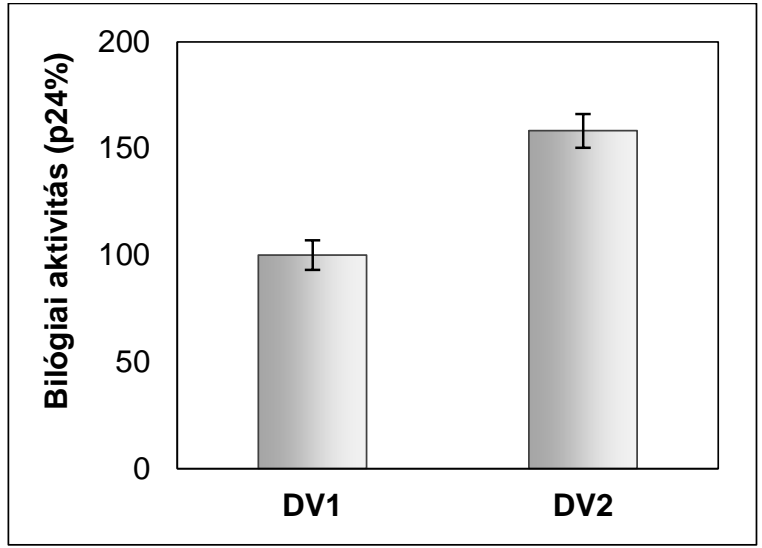

B

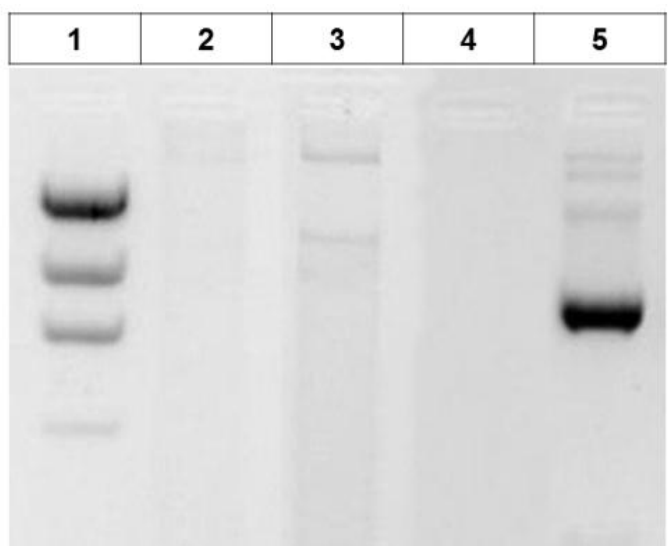

29. Ábra. A DV1 (jelenlegi klinikai) és a DV2 (új) formulációk összehasonlítása. A) Biológiai aktivitás vizsgálatban. B) Endonukleázzal szembeni ellenálló képességben. Zsebek: 1-marker, 2-DV1 (jelenlegi klinikai formuláció) aspecifikus endonukleázzal való emésztés majd SDS dekomplexálás után, 3-DV2 (új formuláció) aspecifikus endonukleázzal való emésztés majd SDS dekomplexálás után, 4- pDNS aspecifikus endonukleázzal való emésztés után, 5-kontroll, kezeletlen pDNS.

Kimutattuk és bizonyítottuk, hogy az egyszerü UV-fotometriás vizsgálattal mérhető abszorbancia-emelkedés (hiperkromofória) a DermaVir kialakulásakor arányos a foszfátok és az aminok között kialakuló kötések számával. Elméletünket igazoltuk számos független módszerrel. Bebizonyítottuk, hogy a komponensek (pDNS és PEIm) ionos jellege befolyásolja a hiperkromofóriát, vagyis a kialakuló kötések számát. A jelenlegi klinikai formuláció a magas protonáltságú PEIm-mel, a magas NaCl-tartalmú pDNS-sel és a 3-4 közötti pH-val, a mért alacsony hiperkromofóriájával és kisebb biológiai aktivitásával ebbe a csoportba tartozik, ahol a részecske a sejten belül túl hamar szétesik (30. Ábra, A), ezt mutatja a róla készült AFM felvétel is (27. Ábra, B). Ezzel ellentétben a glicerin-tartalmú formulációknál látott magas hiperkromofória a kötések túl nagy számával magyarázható, amit alátámaszt az is, hogy az SDS dekomplexálás módszerével nem lehetett dezintegrálni a részecskét, és a biológiai aktivitás csökkenése is utalhat arra, hogy a részecske túlságosan stabil, nem esik szét időben a sejtben (30. Ábra, B). 


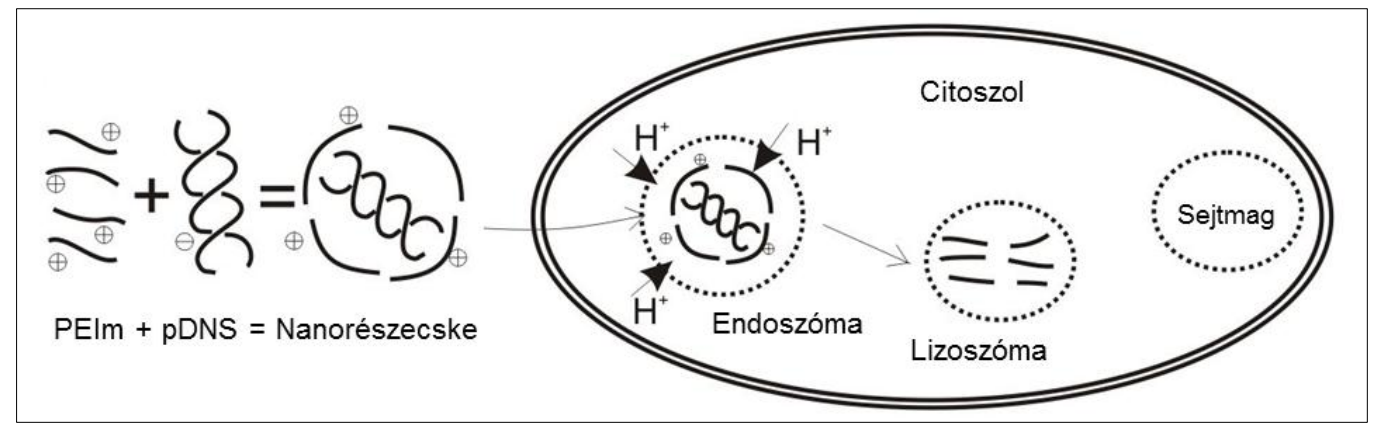

B

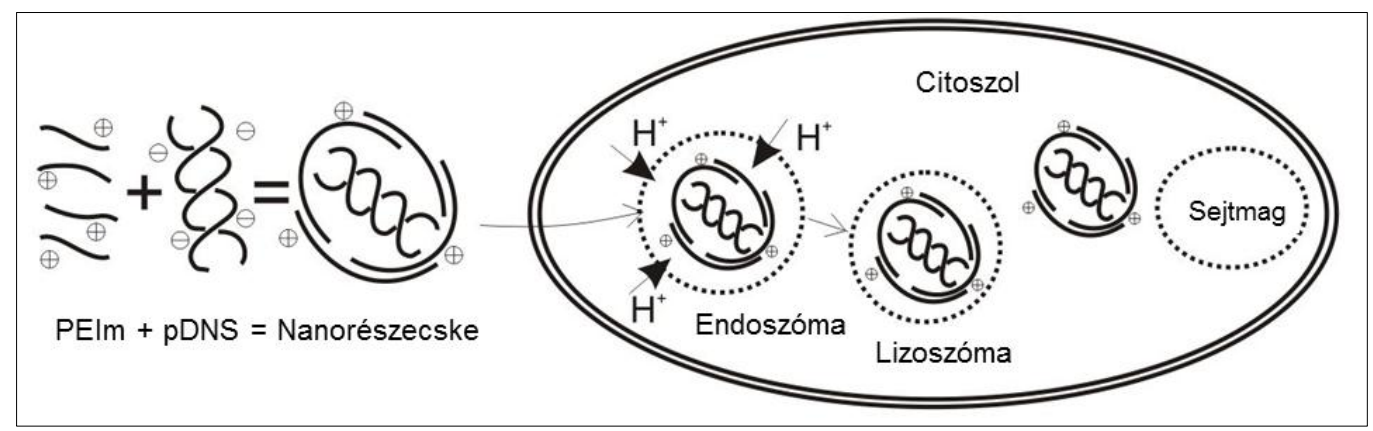

$\mathrm{C}$

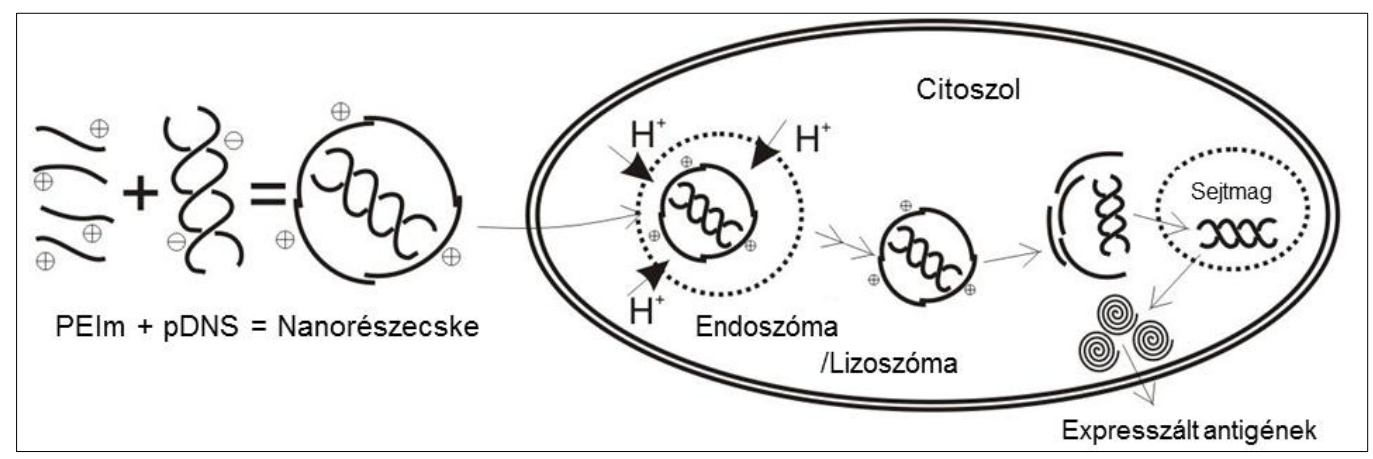

30. Ábra. Sematikus ábra: a hiperkromofória, vagyis a nanorészecske kompaktságának hatása a sejten belüli mechanizmusra. A) Alacsony hiperkromofória, vagyis a komponensek közötti kötések kis száma esetén a részecske nem éli túl az endoszómát. B) Magas hiperkromofória, vagyis a komponensek közötti kötések nagy száma esetén a részecske nem engedi el időben a pDNS-t, hogy az beléphessen a sejtmagba. C) Optimális hiperkromofória, vagyis a komponensek közötti kötések optimális száma esetén a részecske túléli az endoszómát és a sejtmag előtt dekomplexálódva a pDNS bejut, a magba, magas a génexpresszió.

Ideális esetben a hiperkromofóriának, vagyis a pDNS és a PEIm közötti kötések számának optimuma van, ami se nem túl nagy, se nem túl alacsony. Így a megfelelő kompaktságú nanorészecske jön létre, amiben az ideális kationos jellegü PEIm elegendő számú kötést 
alakít ki a megfelelően kevés $\mathrm{NaCl}$-ot tartalmazó pDNS-sel, hogy a részecske be tudjon jutni a sejtbe. Ott a polimer semleges nitrogénjei puffereljék az endoszómát és megvédje a pDNS-t a degradációtól, majd a sejtmagig eljutva, ott időben elengedje a pDNS-t, hogy az bejuthasson a magba a hatékony génexpresszió eléréséhez (30. Ábra, C). ${ }^{124,125}$ Az új formuláció, az optimális protonáltságú PEIm-mel, a csaknem NaCl-mentes pDNS-sel és a fiziológiás pH-t biztosító TEAM pufferrel optimális hiperkromofóriát és magas biológiai aktivitást mutat, ahogy szerkezetének kompaktsága is jól látható az AFM felvételeken a jelenlegi klinikai formulációhoz képest (27. Ábra, D).

Felállítottuk tehát a nanorészecske sejten belüli mechanizmusának elméletét és kísérletekkel alátámasztottuk a biológiai aktivitás és a hiperkromofória, mint új, a szerkezetre jellemző paraméter összefüggését. A hiperkromofória jelenségének felismerésével, annak feltérképezésével és a különböző körülmények összefüggésbe hozatalával érthetővé vált a DermaVir új formulációjának kiugró stabilitása a jelenlegi formulációhoz képest. A fejlesztési munka során megismert kritikus minőségi paraméterek leginkább a komponensek ionos jellegéből adódtak, ezek a PEIm, illetve a pDNS specifikációjába kerültek be, ezért a DermaVir nanorészecske specifikációja a részecskeméret és a pH paraméterekre vonatkozó határértékekkel bővült (20. Táblázat).

20. Táblázat. A DermaVir nanomedicína kibővített specifikációja.

\begin{tabular}{lcc}
\multicolumn{1}{c}{ Paraméter } & Módszer & Elfogadási kritérium \\
\hline Megjelenés & Szemrevételezés & Tiszta, színtelen oldat \\
Azonosság & Agaróz gélelektroforézis & Nincs migráció \\
Tartalom & $\begin{array}{l}\text { Spektrofotometria } 260 \mathrm{~nm} \text {-en a } \\
\text { részecske dekomplexálása után }\end{array}$ & $0,125 \pm 0,0125 \mathrm{mg} / \mathrm{mL}$ pDNS \\
Biológiai aktivitás & Transzfekciós módszer & $\geq 70 \%$ referencia standard \\
pH & pH-metria & $7,5 \pm 0,2$ \\
Részecskeméret & Dinamikus fényszórás & $70 \mathrm{~nm} \leq \mathrm{D}_{\text {Eff }} \leq 300 \mathrm{~nm}$ \\
\hline
\end{tabular}


A DermaVir nanomedicína tehát a kétfiolás fagyasztott formulációval kezdi meg a fázis III-as klinikai vizsgálatokat, és lép majd a piacra az engedélyeztetés után. Ez a multidiszciplináris fejlesztés segítségével feljavított, kémiailag optimalizált formuláció a jelenlegi klinikaihoz képest egyszerübb kezelést és tárolást igényel, magasabb biológiai aktivitást és nagyságrendekkel hosszabb stabilitást mutat a fent bizonyított stabilabb szerkezete miatt, mindemellett a hatóság számára a szinte változatlan forma miatt nem igényel kiegészítő toxikológiai és biztonságossági vizsgálatokat. 


\section{KöSZÖNETNYILVÁNÍTÁS}

Ezúton szeretnék köszönetet mondani témavezetőmnek Dr. Lisziewicz Juliannának, és Dr. Tőke Enikőnek. Külön köszönöm Dr. Somogyi Eszternek a biológiai folyamatok értelmezésében nyújtott segítségét, valamint a teljes Genetic Immunity csapatnak a sok-sok munkát, amit a fenti fejlesztésbe vetettek és vetnek ma is.

Külön köszönettel tartozom a volt egyetemi témavezetőmnek, Dr. Gyurcsik Bélának azért, hogy lehetővé tette a PEIm potenciometriás titrálását és segített az eredmények értékelésében és értelmezésében.

Végül, de nem utolsó sorban köszönöm a lelkes együttmüködőknek, Dr. Jack Douglas-nek, Dr. Horkay Ferencnek, Dr. Preethi Chandran-nak és Dr. Szebeni Jánosnak a közös munkát.

Végezetül hálásan köszönöm édesanyámnak, nővéremnek és páromnak, hogy személyes támogatásukkal és bátorításukkal hozzájárultak e dolgozat létrejöttéhez. 


\section{6. ÖSSZEFOGLALÓ}

Munkám során egy olyan innovatív nanomedicína termékjelölt, a DermaVir formulációjának fejlesztésében vettem részt, amely jelenleg fázis II-es klinikai stádiumban van, HIV és AIDS elleni terápiás vakcinaként. Napjainkban a HIV-fertőzés és az AIDS a világ egyik legnagyobb egészségügyi kihívása. Jelenleg több mint 30 millió regisztrált HIV-fertőzött van világszerte, akik közül mindössze kb. 5 milliót kezelnek a ma elérhető gyógyszeres terápiával. A vírusellenes gyógyszerek forradalmasították ugyan a fertőzés kezelését, de csak az AIDS-betegség késleltetett kialakulását okozzák, végleges gyógyulást nem hoznak. Emiatt nagy hangsúlyt fektetnek ma is a megfelelö ellenszer (preventív vagy terápiás) megtalálására. A DermaVir nanomedicína hatóanyaga egy plazmid DNS (pDNS), amely a HIV vírus 15 fehérjéjét kódolja. Ezt a pDNS-t egy mannozilált lineáris polietilénimin (PEIm) polikation segítségével 100-300 nm-es nanorészecskékké, poliplexekké kondenzáljuk. A nanorészecskék a két oldat összekeverésével, spontán önrendeződő folyamatban alakulnak ki, melyben a plazmid negatív töltésű foszfát csoportjai ionos kötéseket alakítanak ki a polimer pozitív töltésü szekunder amin csoportjaival. Az így kialakuló részecskék „patogén-szerü” nanorészecskék, mivel méretük, alakjuk és felületi tulajdonságaik kórokozókra jellemzőek. A nanorészecske szuszpenziót transzdermális tapasz segítségével alkalmazzuk, a bőrben található antigén prezentáló sejteket célozva, melyek felveszik őket, majd a nyirokcsomókba juttatják, ahol a pDNS-ben kódolt fehérjék átíródása után bemutatják őket a naiv T-sejteknek, így generálva specifikus immunválaszt a betegség ellen. Ez a technológia platform technológiának tekinthető, mivel a pDNS-ben kódolt információ változtatásával más fertőző betegségek, rákos- vagy allergiás megbetegedések kezelésére is alkalmas patogénszerü nanorészecskét állíthatunk elő.

A DermaVir nanomedicína eddig klinikán használt formulációját a kezelés helyszínén frissen keveri össze a klinikai gyógyszerész három, különböző hőmérsékleten tárolt komponensből (pDNS $-80^{\circ} \mathrm{C}, \quad$ PEIm $-20^{\circ} \mathrm{C}$ és $10 \%$ glükóz/dextróz szobahőmérséklet), majd 3 órán belül fel is kell azt használni, nagyon rövid stabilitása miatt. A cél egy stabil formuláció kidolgozása. Mivel azonban ez a termék már túl van a szükséges toxikológiai vizsgálatokon, így a fejlesztésben csak olyan paramétereket 
változtathatunk, melyek után nem szükségesek újabb biztonságossági klinikai vizsgálatok, amelyek évekkel késleltethetnék a termék piacra kerülését. Miután a nanomedicínának nem csak a kompozíciója (plazmid DNS hatóanyag), de a hatásmechanizmus is innovatív, a részecske szerkezet-aktivitás összefüggése is vizsgálat tárgya.

A formuláció fejlesztése során a két fő komponens, a pDNS és a PEIm esetében is megfigyeltük, hogy azok különböző sarzsai különböző biológiai aktivitást mutattak, annak ellenére, hogy akkori minőségi követelményüknek (specifikációjuknak) megfeleltek GMP gyártást követően. Részletes elemanalízis során kiderült, hogy mindkét komponens esetében az ionos jelleg az, ami eltérő a sarzsok között. A hatékony génexpresszió megörzéséhez és a stabilitás eléréséhez a komponenseket külön-külön és a rendszert egészében is vizsgálat alá vettük és megtaláltuk a kritikus paraméterek optimumát, ennek eredményeképp pedig kibővítettük az anyagok specifikációját. A nanorészecske egészének tanulmányozása során a polimerrel összeférhetetlen glükóz oldatot, ami a formuláció oldószereként szerepelt, lecseréltük egy 7,5-ös pH-jú, mannitoltartalmú trietanolaminhidroklorid pufferre, amely nem okoz mellékreakciót és emellett magas biológiai aktivitást biztosít. Kidolgoztunk egy stabil folyadék- formulációt, mely az irodalomban eddig egyedülálló stabilitást mutatott: $37^{\circ} \mathrm{C}$-on 3 hétig, $4^{\circ} \mathrm{C}$-on 8 hétig tárolva a frissen készített kontrollal megegyező in vitro biológiai aktivitást mérhettünk. ${ }^{40}$ A folyadék-formulációval párhuzamosan egy olyan kétfiolás, $-20^{\circ} \mathrm{C}$-on tárolt formulációt is kidolgoztunk, melynél kiolvasztás után a két komponens (a pufferrel hígított pDNS és a PEIm) egyszerüen összekeverhető. Ez a formuláció 1 éves stabilitás adattal rendelkezik, a jelenlegi klinikaival ellentétben nem igényel különleges tárolási körülményeket, nem kell klinikai gyógyszerésznek elkészítenie bonyolult elöírás szerint, elegendő a nővér az adminisztrációhoz.

A fejlesztési munka során feltérképeztük a DermaVir nanomedicína szerkezetaktivitás összefüggéseit is. Ennek során a jelenlegi klinikai nanorészecske-szuszpenziót vizsgáltuk az optimalizált újjal szemben. Atomerő mikroszkópos felvételekről kiderült, hogy a két formuláció közötti biológiai aktivitás különbséget a részecskék finomszerkezetének különbsége okozza. Több fizikokémiai tulajdonságot is vizsgálva azt találtuk, hogy kizárólag a részecskék UV spektrofotometriásan mérhető hiperkromofóriája az a paraméter, amely összefüggésbe hozható a biológiai aktivitásbeli eltérésekkel; ez az új, eddig nem vizsgált paraméter ad információt a szerkezetek különbözőségéről. ${ }^{120} \mathrm{~A}$ 
hiperkromofória jelenségét több oldalról vizsgálva azt találtuk, hogy a formuláció ionerősségével és a pH-val van összefüggésben. Felállítottuk a részecske sejten belüli processzálásának mechanizmusát, és igazoltuk AFM felvételekkel, valamint gél retardációs kísérlettel, nukleáz enzimmel szembeni ellenállás vizsgálattal és termodinamikai stabilitás vizsgálatokkal is.

A DermaVir nanomedicína az újonnan kidolgozott kétfiolás fagyasztott formulációval fogja megkezdeni a fázis III-as klinikai vizsgálatokat. Mindemellett, a szinte változatlan összetétel miatt nem igényel kiegészítő toxikológiai és biztonságossági vizsgálatokat. Ez az optimalizált formuláció a jelenlegi klinikaihoz képest egyszerübb kezelést és tárolást igényel, magasabb biológiai aktivitást és nagyságrendekkel hosszabb stabilitást mutat a fent bizonyított stabilabb szerkezete miatt. 


\section{SUMMARY}

During my work I participated in the formulation development of an innovative nanomedicinal product-candidate, the DermaVir which is a phase II clinical stage investigational medicinal product for the treatment of HIV/AIDS. Today HIV infection and the disease of AIDS is one of the most urgent unmet medical needs. There is more than 30 million HIV infected people worldwide, from whom only 5 million receives the available antiretroviral therapy. Although the antiviral drugs improved the treatment of the disease, they do not provide cure only delay the development of AIDS. Therefor the development of appropriate medicament (both preventive and therapeutic) is still a problem to be solved. The active pharmaceutical ingredient of DermaVir nanomedicine is a plasmid DNA (pDNA) encoding 15 major antigens of the HIV. This pDNA is condensed into 100-300 $\mathrm{nm}$ nanoparticles (or polyplexes) using a cationic mannosilated linear polyethylenimine (PEIm). Nanoparticles are formed spontaneously when the pDNA and PEIm solutions are mixed; the negative phosphate groups of the pDNA and the positive secondary amines of the PEIm evolve ionic interactions and self-assemble into nanoparticles. The formed nanoparticles are pathogen-like nanoparticles as their size, shape and surface properties resemble pathogens. The suspension of the nanoparticles is administered using a transdermal patch that targets the antigen presenting cells of the skin. These cells take up the particles which are recognized as pathogens and take them to the lymph nodes, where the pDNA encoded antigens are expressed, presented to the naive $\mathrm{T}$ cells thus generating specific immune response against the disease. This is a platform technology as the pDNA sequence can be changed to encode various antigens against other infectious diseases, cancer or allergy.

The formulation of DermaVir nanomedicine currently on the clinic is prepared freshly by a clinical pharmacist from 3 components stored at 3 different temperatures (pDNA $-80^{\circ} \mathrm{C}, \mathrm{PEIm}-20^{\circ} \mathrm{C}$ and $10 \%$ glucose/dextrose room temperature), and use within 3 hours because of the poor stability. The aim is to develop a stable formulation taking into consideration that the necessary safety and toxicology studies are already accomplished for the product thus the parameters which could be modified in the formulation are limited, to avoid the need of additional safety/toxicology studies which would delay the marketing 
approval. As not only the composition is innovative but also the mechanism of action of the nanomedicine, the structure-activity relationship is also studied.

While developing a new formulation we observed that there is great difference between the biological activity of the different lots of the two main components, pDNA and PEIm, although each of them fulfilled specifications and were manufactured in GMP. Detailed elemental analysis of the components revealed that in both cases (pDNA and PEIm) is the ionic character which varies from lot to lot. To maintain potent biological activity and achieve stability we investigated the components alone and also the system together, we found the optimum of the crucial parameters, extended their specification and developed a stable, liquid formulation with the same biological activity as the fresh control after storage of 8 weeks at $4{ }^{\circ} \mathrm{C}$ and 3 weeks at $37^{\circ} \mathrm{C} .{ }^{40}$ Parallel the liquid formulation we were also working on a two-vial formulation stored at $-20^{\circ} \mathrm{C}$, where after thawing the two vials can be simply mixed together. This formulation bears 1 year stability and unlike the old one, needs no special storage $\left(-80^{\circ} \mathrm{C}\right)$, or clinical pharmacist for preparation, a nurse can easily mix the two solutions.

During the development work we also studied the structure-activity relationship of DermaVir nanomedicine; we compared the old formulation with glucose with the new (TEAM buffer containing) one. Atomic force microscopy images showed that the different biological activity of the formulations is caused by the different fine structure of the nanoparticles. The investigation of more physico-chemical properties revealed that only the new phenomenon of the hyperchromicity of the nanoparticles (measured by UVspectrophotometry) can be associated with the difference of the biological activities and structure. ${ }^{120}$ When exploring the phenomenon of hyperchromicity we found that the ionic strength and the $\mathrm{pH}$ are the most important parameters. We set up the mechanism of the nanoparticles' intracellular processing and confirmed it with AFM images, agarose gelelectrophoresis assays, nuclease-enzyme resistance assay and thermodynamic stability test.

DermaVir nanomedicine will start phase III clinical trials with the newly developed two-vial formulation. Besides, the almost unchanged composition there is no need for additional safety or toxicology studies. This optimized formulation provides more simple 
handling and storage, higher biological activity and orders of magnitude longer stability because of the above proven stable structure. 


\section{IRODALOMJEGYZÉK}

${ }^{1}$ Feltquate, D.M., Heaney, S., Webster, R.G., Robinson, H.L. Different T helper cell types and antibody isotypes generated by saline and gene gun DNA immunization. J. Immunol. 1997, 158, 2278-2284.

${ }^{2}$ Wolff, J.A., Budker, V. The mechanism of naked DNA uptake and expression. $A d v$. Genet. 2005, 54, 3-20.

${ }^{3}$ Neumann, E., Schaefer-Ridder, M., Wang, Y., Hofschneider, P.H. Gene transfer into mouse lyoma cells by electroporation in high electric fields. EMBO. J. 1982, 1, 841-845.

${ }^{4}$ Abdulhaqq, S.A., Weiner, D.B. DNA vaccines: developing new strategies to enhance immune responses. Immunol Res. 2008, 42, 219-32.

${ }^{5}$ Trombone, A.P., Silva, C.L., Lima, K.M., Oliver, C., Jamur, M.C., Prescott, A.R., Coelho-Castelo, A.A. Endocytosis of DNA-Hsp65 alters the $\mathrm{pH}$ of the late endosome/lysosome and interferes with antigen presentation. PLoS One. 2007, 26, e923.

${ }^{6}$ Alarcon, J.B., Waine, G.W., McManus, D.P. DNA vaccines: technology and application as anti-parasite and anti-microbial agents. Adv. Parasitol. 1999, 42, 343-410.

${ }^{7}$ Medina-Kauwe, L.K. Endocytosis of adenovirus and adenovirus capsid proteins. $A d v$. Drug. Deliv. Rev. 2003, 14, 1485-1496.

${ }^{8}$ Larocca, C., Schlom, J. Viral vector-based therapeutic cancer vaccines. Cancer J. 2011, $17,359-371$.

${ }^{9}$ Cao, X., Wei, R., Liu, X., Zeng, Y., Huang, H., Ding, M., Zhang, K., Liu, X.Y. Cancer targeting Gene-Viro-Therapy specific for liver cancer by alpha-fetoprotein-controlled oncolytic adenovirus expression of SOCS3 and IL-24. Acta. Biochim. Biophys. Sin. 2011, $43,813-821$. 
${ }^{10}$ Breen, A., Strappe, P., Kumar, A., O’Brien, T., Pandit, A. Optimization of a fibrin scaffold for sustained release of an adenoviral gene vector. J. Biomed. Mater. Res. A. 2006, 78, 702-708.

${ }^{11}$ Lilley, C.E., Branston, R.H., Coffin, R.S. Herpes simplex virus vectors for the nervous system. Curr. Gene Ther. 2001, 4, 339-358.

${ }^{12}$ Woods, N.B., Bottero, V., Schmidt, M., von Kalle, C., Verma, I.M. Gene therapy: therapeutic gene causing lymphoma. Nature. 2006, 440, 1123-1130.

${ }^{13}$ Resina, S., Prevot, P., Thierry, A.R. Physico-Chemical Characteristics of Lipoplexes Influence Cell Uptake Mechanisms and Transfection Efficacy. PLoS ONE. 2009, 4, e6058.

14 Gomez-Hens, A., Fernandez-Romero, J.M. Analytical methods for the control of liposomal delivery systems. Trends Anal. Chem. 2006, 25, 167-178.

15 Mozafari, M.R., Johnson, C., Hatziantoniou, S. \& Demetzos, C. Nanoliposomes and their applications in food nanotechnology. J. Liposome Res. 2008, 18, 309-327.

16 Mozafari, M.R. \& Mortazavi, S.M. Nanoliposomes: From Fundamentals to Recent Developments. Trafford Publishing Ltd, 2005, Oxford, UK.

${ }^{17}$ Piechaczek, C., Fetzer, C., Baiker, A., Bode, J., Lipps, H.J. A vector based on the SV40 origin of replication and chromosomal S/MARs replicates episomally in CHO cells. Nucleic Acids Res. 1999, 27, 426-428.

${ }^{18}$ Garcea RL. \& Gissmann, L. Virus-like particles as nanomedicines and vessels for the delivery of small molecules. Curr. Opin. Biotechnol. 2004, 15, 513-517.

${ }^{19}$ Jeong, J.H., Sung, W.K. \& Park, T.G. Molecular design of functional polymers for gene therapy. Prog. Polym. Sci. 2007, 32, 1239-1274.

${ }^{20}$ Zuber, G., Dauty, E., Nothisen, M., Belguise, P. \& Behr, J.P. Towards synthetic viruses. Adv. Drug Deliv. Rev. 2001, 52, 245-253.

${ }^{21}$ Louise, C. Nonviral vectors. Methods Mol Biol. 2006, 333, 201-226. 
${ }^{22}$ Dubruel, P., Schacht, E. Vinyl polymers as non-viral gene delivery carriers: current status and prospects. Macromol Biosci. 2006, 20, 789-810.

${ }^{23}$ Chen, J., Tian, B., Yin, X., Zhang, Y., Hu, D., Hu, Z., Liu, M., Pan, Y., Zhao, J., Li, H., Hou, C., Wang, J., Zhang, Y. Preparation, characterization and transfection efficiency of cationic PEGylated PLA nanoparticles as gene delivery systems. J Biotechnol. 2007, 130, 107-113.

${ }^{24}$ De Smedt, S.C., Demeester, J., Hennink, W.E. Cationic polymer based gene delivery systems. Pharm. Res. 2000, 17, 113-126.

${ }^{25}$ Lobo, B.A., Koe, G., Smith, J.G. \& Middaugh, C.R. Isothermal Titration Calorimetric Analysis of the Interaction Between Cationic Lipids and Plasmid DNA. Arch. Biochem. Biophys. 2001, 386, 95-105.

26 Zuidam, N.J. \& Barenholz, Y. Electrostatic and structural properties of complexes involving plasmid DNA and cationic lipids commonly used for gene delivery. Biochim. Biophys. Acta. 1998, 1368, 115-128.

${ }^{27}$ Kleemann, E. et al. Modified polyethylenimines as non-viral gene delivery systems for aerosol gene therapy: investigations of the complex structure and stability during air-jet and ultrasonic nebulization. J. Contr. Rel. 2004, 100, 437-450.

${ }^{28}$ Remy, J. et al. Gene transfer with lipospermines and polyethylenimines. $A d v$. Drug Deliv. Rev. 1998, 30, 85-95.

${ }^{29}$ Sternberg, B., Sorgi, F.L. \& Huang, L. New structures in complex formation between DNA and cationic liposomes visualized by freeze-fracture electron microscopy. FEBS Lett. 1994, 356, 361-366.

${ }^{30}$ Abdallah, B., Hassan, A., Benoist, C., Goula, D., Behr, J.P.,Demeneix, B.A. A powerful nonviral vector for in vivo gene transfer into the adult mammalian brain: polyethylenimine. Hum. Gene Ther. 1996, 7, 1947-1954.

${ }^{31}$ Boletta, A., Benigni, A., Lutz, J., Remuzzi, G., Soria, M.R., Monaco, L. Nonviral gene delivery to the rat kidney with polyethylenimine. Hum. Gene Ther. 1997, 8, 1243-51. 
${ }^{32}$ Choosakoonkriang, S., Lobo, B. A., Koe, G. S., Koe, J.G., Middaugh, C.R. Biophysical characterization of PEI/DNA complexes, J. Pharm. Sci. 2003, 92, 1710-1722.

${ }^{33}$ Fischer, D., Bieber, T., Li, Y., Elsasser, H.P., Kissel, T. A novel non-viral vector for DNA delivery based on low molecular weight, branched polyethylenimine: effect of molecular weight on transfection efficiency and cytotoxicity. Pharm. Res. 1999, 16, $1273-$ 1279.

34 Brus, C., Kleemann, E., Aigner, A., Czubayko, F., Kissel, T. Stabilization of oligonucleotide-polyethylenimine complexes by freeze-drying: physicochemical and biological characterization. J. Contr. Rel. 2004, 95, 119-131.

${ }^{35}$ Gomes dos Santos, A.L., Bochot, A., Tsapis, N., Artzner, F., Bejjani, R.A., ThillayeGoldenberg, B., et al. Oligonucleotide-polyethylenimine complexes targeting retinal cells: structural analysis and application to anti-TGFbeta-2 therapy. Pharm. Res. 2006, 23, 770781.

${ }^{36}$ Werth, S., Urban-Klein, B., Dai, L., Hobel, S., Grzelinski, M., Bakowsky, U., et al. A low molecular weight fraction of polyethylenimine (PEI) displays increased transfection efficiency of DNA and siRNA in fresh or lyophilized complexes. J. Contr. Rel. 2006, 112, $257-270$.

${ }^{37}$ Urban-Klein, B., Werth, S., Abuharbeid, S., Czubayko, F., Aigner, A. RNAi-mediated gene-targeting through systemic application of polyethylenimine (PEI)-complexed siRNA in vivo. Gene Ther. 2005, 12, 461-466.

38 von Harpe, A., Petersen, H., Li, Y., Kissel, T. Characterization of commercially available and synthesized polyethylenimines for gene delivery. J. Contr. Rel. 2000, 69, 309-322.

39 Jeong, J.H., Song, S.H., Lim, D.W., Lee, H., Park, T.G. DNA transfection using linear poly(ethylenimine) prepared by controlled acid hydrolysis of poly(2-ethyl-2-oxazoline). $J$. Contr. Rel. 2001, 73, 391-399. 
40 Tőke, E.R., Lőrincz, O., Somogyi, E., Lisziewicz, J. Rational development of a stable liquid formulation for nanomedicine products. Int. J. Pharm. 2010, 392, 261-267.

${ }^{41}$ Boussif, O. et al. A versatile vector for gene and oligonucleotide transfer into cells in culture and in vivo: Polyethylenimine. Proc. Natl. Acad. Sci. 1995, 92, 7297-7301.

${ }^{42}$ Suh, J., Paik, H.J., Hwang, B.K. Ionization of polyethyleneimine and polyallylamine at various pHs. Bioorg. Chem 1994, 22, 318-27.

${ }^{43}$ Wightman, L., Kircheis, R., Rossler, V., Carotta, S., Ruzicka, R., Kursa, M., et al. Different behavior of branched and linear polyethylenimine for gene delivery in vitro and in vivo. J. Gene. Med. 2001, 3, 362-372.

${ }^{44}$ Godbey, W.T., Barry, M.A., Saggau, P., Wu, K.K., Mikos, A.G. Poly(ethylenimine)mediated transfection: a new paradigm for gene delivery. J. Biomed. Mater. Res. 2000, 51, $321-328$.

45 Godbey, W.T., Wu, K.K., Mikos, A.G. Tracking the intracellular path of poly(ethylenimine)/DNA complexes for gene delivery. Proc. Natl. Acad. Sci. 1999, 96, $5177-5181$.

${ }^{46}$ K. Itaka, A. Harada, Y. Yamasaki, et al., In situ single cell observation by fluorescence resonance energy transfer reveals fast intra-cytoplasmic delivery and easy release of plasmid DNA complexed with linear polyethylenimine. J. Gene. Med., 2004, 6, 76-84.

${ }^{47}$ Hongtao, L., Zhang, S., Wang, B., Cuib, S., Yanc, J. Toxicity of cationic lipids and cationic polymers in gene delivery. J. Contr. Rel. 2006, 114, 100-109.

${ }^{48}$ Gautam, A., Densmore, C.L., Xu, B., Waldrep J.C. Enhanced gene expression in mouse lung after PEI-DNA aerosol delivery. Mol. Ther. 2000 ,2, 63-70.

${ }^{49}$ Gharwan, H., Wightman, L., Kircheis, R., Wagner, E., Zatloukal, K. Nonviral gene transfer into fetal mouse livers (a comparison between the cationic polymer PEI and naked DNA). Gene Ther. 2003, 10, 810-817. 
${ }^{50}$ Goula, D., Remy, J.S., Erbacher, P., Wasowicz, M., Levi, G., Abdallah, B., et al. Size, diffusibility and transfection performance of linear PEI/DNA complexes in the mouse central nervous system. Gene Ther. 1998, 5, 712-717.

${ }^{51}$ Coll, J.L., Chollet, P., Brambilla, E., Desplanques, D., Behr, J.P., Favrot, M. In vivo delivery to tumors of DNA complexed with linear polyethylenimine. Hum. Gene Ther. 1999, 10, 1659-1666.

52 Iwai, M., Harada, Y., Tanaka, S., Muramatsu, A., Mori, T., Kashima, K., et al. Polyethylenimine-mediated suicide gene transfer induces a therapeutic effect for hepatocellular carcinoma in vivo by using an Epstein-Barr virus-based plasmid vector. Biochem. Biophys. Res. Commun. 2002, 291, 48-54.

${ }^{53}$ http://clinicaltrials.gov/ct2/show/NCT01274455?term=NCT01274455\&rank=1

54 Vernejoul, F., Ghénassia, L., Souque, A., Lulka, H. Drocourt, D., Cordelier, P., Pradayrol, L., Pyronnet, S., Buscail, L., Tiraby, G. Gene Therapy Based on Gemcitabine Chemosensitization Suppresses Pancreatic Tumor Growth. Mol. Ther. 2006, 14, 758-767.

${ }^{55}$ Anwer, K., Barnes, M.N., Fewell, J., Lewis, D.H., Alvarez, R.D. Phase-I clinical trial of IL-12 plasmid/lipopolymer complexes for the treatment of recurrent ovarian cancer. Gene Ther. 2010, 17(3), 360-369.

${ }^{56}$ Lappalainen, K., Urtti, A., Söderling, E., Jääskeläinen, I., Syrjänen, K. and Syrjänen, S. Cationic liposomes improve stability and intracellular delivery of antisense oligonucleotides into CaSki cells. Biochem. Biophys. Acta. 1994, 1196, 201-208.

${ }^{57}$ Bennett, C.F., Chiang, M.Y., Chan, H., Shoemaker, J.E.E. and Mirabelli, K. Cationic lipids enhance cellular uptake and activity of phosphorothioate antisense oligonucleotides. Mol. Pharmacol. 1992, 41, 1023-1033.

${ }^{58}$ Salvati A., Ciani L., Ristori, S., Martini, G., Masi, A., Arcangeli, A. Physico-chemical characterization and transfection efficacy of cationic liposomes containing the pEGFP plasmid. Biophys. Chem. 2006, 121, 21-29. 
${ }^{59}$ Srinivasachar, S., Liu, Y., Prevette, L.E., Reineke, T.M. Effects of trehalose click polymer length on pDNA complex stability and delivery efficacy. Biomaterials. 2007, 28, 2885-2898.

${ }^{60}$ Evans, R.K., Xu, Z., Bohannon, K.E. Wang, B., Bruner, M.W., Volkin, D.B. Evaluation of degradation pathways for plasmid dna in pharmaceutical formulations via accelerated stability studies. J. Pharm. Sci. 2000, 89, 76-87.

${ }^{61}$ Lindahl, T. Instability and decay of the primary structure of DNA. Nature. 1993, 362, $709-715$.

${ }^{62}$ Ohana, P., Gofrit, O., Ayesh, S., Al-Sharef, W., Mizrahi, A., Birman, T., Schneider, T., Matouk, I., de Groot, N., Tavdy, E., Sidi, A., Hochberg, A. Regulatory sequences of the H19 gene in DNA based therapy of bladder cancer. Gene Ther. Mol. Biol. 2004, 8, 181 192.

${ }^{63}$ Neu, M., Fischer, D., Kissel, T. Recent advances in rational gene transfer vector design based on poly(ethylene imine) and its derivatives. J. Gene Med. 2005, 7, 992-1009.

${ }^{64}$ Molina, M.C., Allison, S.D., Anchordoquy, T.J. Maintenance of nonviral vector particle size during the freezing step of the lyophilization process is insufficient for preservation of activity: insight from other structural indicators. J. Pharm. Sci. 2001, 90, 1445-1455.

65 Anchordoquy, T.J., Armstrong, T.K., Molina, M.C. Low molecular weight dextrans stabilize nonviral vectors during lyophilization at low osmolalities: concentrating suspensions by rehydration to reduced volumes. J. Pharm. Sci. 2005, 94, 1226-1236.

66 Hobel, S., Prinz, R., Malek, A., Urban-Klein, B., Sitterberg, J., Bakowsky, U., Czubayko, F., Aigner, A. Polyethylenimine PEI F25-LMW allows the long-term storage of frozen complexes as fully active reagents in siRNA-mediated gene targeting and DNA delivery. Eur. J. Pharm. Biopharm. 2008, 70, 29-41.

${ }^{67}$ Barré-Sinoussi, F., Chermann, J.C., Rey, F., Nugeyre, M.T., Chamaret, S., Gruest, J., Dauguet, C., Axler-Blin, C., Vézinet-Brun, F., Rouzioux, C., Rozenbaum, W., Montagnier, 
L. Isolation of a T-Lymphotropic Retrovirus from a Patient at Risk for Acquired Immune Deficiency Syndrome (AIDS). Science. 1983, 220, 868-871.

${ }^{68}$ Marx, J. L. Strong new candidate for AIDS agent. Science. 1984, 224, 475-477.

${ }^{69}$ Marx, J. L. A virus by any other name? Science. 1985, 227, 1449-1451.

${ }^{70}$ Coffin, J., Haasen, A., Levy, J. A., Montagnier, L., Oroszlan, S., Teich, N., Temin, H., Toyoshima, K., Varmus, H., Vogt, P. et al. What to call the AIDS virus? Nature. 1986, $321,134-136$.

${ }^{71}$ Sills, J. Unsung Hero Robert C. Gallo. Science. 2009, 323, 206-207.

72 http://www.who.int/hiv/data/en/

73 Lisziewicz, J., Töke, E.R. Nanomedicine applications towards the cure of HIV. Nanomedicine. 2013, 9(1), 28-38.

${ }^{74}$ Lisziewicz, J., Trocio, J., Xu, J., Whitman, L., Ryder, A., Bakare, N., Lewis, M.G., Wagner, W., Pistorio, A., Arya, S., Lori, F. Control of viral rebound through therapeutic immunization with DermaVir. AIDS. 2005, 19, 35-43.

75 Lisziewicz, J., Gabrilovich, D.I., Varga, G., Xu, J., Greenberg, P.D., Arya, S.K., Bosch, M., Behr, J.P., Lori, F. Induction of potent human immunodeficiency virus type 1-specific T-cell-restricted immunity by genetically modified dendritic cells. J. Virol. 2001, 75, 7621-7628.

${ }^{76}$ Lisziewicz, J., Trocio, J., Whitman, L., Varga, G., Xu, J., Bakare, N., Erbacher, P., Fox, C., Woodward, R., Markham, P., Arya, S., Behr, J.P., Lori, F. DermaVir: a novel topical vaccine for HIV/AIDS. J. Invest. Dermatol. 2005, 124, 160-169.

${ }^{77}$ Somogyi, E. et al. A plasmid DNA immunogen expressing fifteen protein antigens and complex virus-like particles (VLP+) mimicking naturally occurring HIV. Vaccine. 2011, $29,744-753$.

${ }^{78}$ Lori, F., Trocio,J., Bakare, N., Kelly, L.M., Lisziewicz, J. DermaVir, a novel HIV immunisation technology. Vaccine. 2005, 23, 2030-2034. 
${ }^{79}$ McGreal, E.P., Martinez-Pomares, L., Gordon, S. Divergent roles for C-type lectins expressed by cells of the innate immune system. Mol. Imm. 2004, 41, 1109-1121.

${ }^{80}$ Asahina, A., Tamaki, K. Role of Langerhans cells in cutaneous protective immunity: Is the reappraisal necessary? J. Dermatol. Sci. 2006, 44, 1-9.

\section{${ }^{81} \mathrm{http}: / / \mathrm{www} . g e n e t i c i m m u n i t y . c o m / G I 0204 . \mathrm{html}$}

${ }^{82}$ Liu, L., Zhong, Q., Tian, T., Dubin, K., Athale, S.K. \& Kupper, T.S. Epidermal injury and infection during poxvirus immunization is crucial for the generation of highly protective T cell-mediated immunity. Nat. Med. 2010, 16, 224-227.

${ }^{83}$ Moser, M., Leo, O. Key concepts in immunology. Vaccine. 2010, 28, C2-C13.

${ }^{84}$ Kushwah, R., Hu, J. Complexity of dendritic cell subsets and their function in the host immune system. Immunology. 2011, 133, 409-419.

${ }^{85}$ Bauer, J. et al. A strikingly constant ratio exists between Langerhans cells and other epidermal cells in human skin. A stereologic study using the optical disector method and the confocal laser scanning microscope. J. Invest. Dermatol. 2001, 116, 313-318.

${ }^{86}$ Irache, J.M., Salman, H.H., Gamazo, C., Espuelas, S. Mannose-targeted systems for the delivery of therapeutics. Expert Opin. Drug Deliv. 2008, 5, 703-724.

${ }^{87}$ Lamaze, C. et al. Interleukin 2 receptors and detergent-resistant membrane domains define a clathrin-independent endocytic pathway. Mol. Cell. 2001, 7, 661-671.

88 Trochilin, V.P. Recent approaches to intracellular delivers of drugs and DNA and organelle targeting. Ann. Rev. Biomed. Eng. 2006, 8, 343-375.

${ }^{89}$ Bruewer, M. et al. Interferon-gamma induces internalization of epithelial tight junction proteins via a macropinocytosis-like process. Faseb. J. 2005, 19, 923-933.

${ }^{90}$ Le Bihan, et. al. Probing the in vitro mechanism of action of cationic lipid/DNA lipoplexes at a nanometric scale. Nucleic Acids Res., 2011, 39, 1595-1609.

91 Suh, J., Wirtz, D., Hanes, J. Efficient active transport of gene nanocarriers to the nucleus. Proc. Natl. Acad. Sci. 2003, 100, 3878-3882. 
${ }^{92}$ Han, X. et al. The heterogeneous nature of polyethylenimine-DNA complex formation affects transient gene expression. Cytotechnology. 2009, 60, 63-75.

${ }^{93}$ Edina Garaczi, E., Szabó, K., Francziszti, L., Csiszovszki, Zs., Lőrincz, O., Tőke, E.R., Molnár, L., Bitai, T., Jánossy, T., Bata-Csörgő, Zs., Kemény, L., Lisziewicz, J. DermAll nanomedicine for allergen-specific immunotherapy. Nanomedicine: NBM. 2013. doi:10.1016/j.nano.2013.05.011.

${ }^{94}$ Lisziewicz, J., Calarota, S., Banhegyi, D., Lisziewicz, Zs., Ujhelyi, E., Lori, F. Single DermaVir Patch treatment of HIV+ individuals induces long-lasting, high-magnitude, and broad HIV-specific $\mathrm{T}$ cell responses. Paper presented at the 15th Conference on Retroviruses and Opportunistic Infections, Boston, MA, USA, 2008, Poster \#715.

95 van Lunzen, J. et al. DermaVir for initial treatment of HIV-infected subjects demonstrates preliminary safety, immunogenicity and HIV-RNA reduction versus placebo immunization. Paper presented at the XVIIIth International AIDS Conference, Vienna, Austria, 2010, Abstract \#A-240-0111-12561.

96 Lisziewicz, J., Bakare, N., Calarota, S.A., Bánhegyi, D., Szlávik, J. et al. Single DermaVir Immunization: Dose-dependent Expansion of Precursor/Memory $\mathrm{T}$ Cells Against All HIV Antigens in HIV-1 Infected Individuals. PLoS ONE. 2012, 7(5), e35416.

${ }^{97}$ Cupillard, L., Juillard, V., Latour, S., Colombet, G., Cachet, N., Richard, S., Blanchard, S., Fischer, L. Impact of plasmid supercoiling on the efficacy of a rabies DNA vaccine to protect cats. Vaccine. 2005, 23, 1910-1916.

${ }^{98}$ Tumanova, I., Boyer, J., Ausar, S.F., Burzynski, J., Rosencrance, D., White, J., Scheidel, J., Parkinson, R., Maguire, H., Middaugh, C.R., Weiner, D., Green, A.P. Analytical and biological characterization of supercoiled plasmids purified by various chromatographic techniques. DNA Cell. Biol. 2005, 24, 819-831.

${ }^{99}$ http://water.epa.gov/scitech/methods/cwa/bioindicators/upload/2007_07_10_methods_m ethod_1650.pdf

100 Zékány, L., Nagypál, I., Computation Methods for the Determination of Formation Constants. Plenum Press, 1991, New York, USA. 
101 Rungsardthong, U., Bailey, L., Armes, S.P., Garnett, M.C., Stolnik, S. Effect of polymer ionization on the interaction with DNA in nonviral gene delivery systems. Biomacromol. 2003, 4, 683-690.

102 Lee, H., Son, S.H., Sharma, R., Won, Y.Y. A discussion of the pH-dependent protonation behaviors of poly(2-(dimethylamino)ethyl methacrylate) (PDMAEMA) and poly(ethylenimine-ran-2-ethyl-2-oxazoline) (P(EI-r-EOz)). J. Phys. Chem. B. 2011, 10, 844-860.

${ }^{103}$ Graham, F.L., Smiley, J., Russell, W.C., Nairn, R. Characteristics of a human cell line transformed by DNA from human adenovirus type 5. J. Gen. Virol. 1977, 36, 59-74.

104 Tjan, S.B., Ouweland, G.A.M.V.D. PMR investigation into the structure of some nsubstituted 1-amino-1-deoxy-D-fructoses (amadori rearrangement products): Evidence for a preferential conformation in solution. Tetrahedron. 1974, 30, 2891-2897.

105 Bhattacharyya, S. Reductive alkylation of dimethylamine using titanium(IV) isopropoxide and sodium borohydride: an efficient, safe, and convenient mathod for the synthesis of N,N-dimethylated tertiary amines, J. Org. Chem. 1995, 60, 4928-4929.

106 Tan, Z.J., Chen, S.J. Nucleic acid helix stability: effects of salt concentration, cation valence and size, and chain length. Biophys. J. 2006, 15, 1175-1190.

${ }^{107}$ Gruenwedel, D.W., Hsu, C.H. Salt effects on the denaturation of DNA. Biopolymers. 1969, 557-570.

${ }^{108}$ Butzow, J.J., Eichhorn, G.L. Different susceptibility of DNA and RNA to cleavage by metal ions. Nature. 1975, 254, $358-359$.

${ }^{109}$ Sreedhara, A., Cowan, J.A. Catalytic hydrolysis of DNA by metal ions and complexes J Biol Inorg Chem. 2001, 6(4), 337-347.

${ }^{110}$ Racoosin, E.L. \& Swanson, J.A. M-CSF-induced macropinocytosis increases solute endocytosis but not receptor-mediated endocytosis in mouse macrophages. J. Cell. Sci. 1992, 102, 867-880. 
111 Kuo, J.-h. S. and Hwang, R. Preparation of DNA dry powder for non-viral gene delivery by spray-freeze drying: effect of protective agents (polyethyleneimine and sugars) on the stability of DNA. J. Pharm. Pharmacol. 2004, 56, 27-33.

112 Bragonzi, A., Boletta, A., Biffi, A., Muggia, A., Sersale, G., Cheng, S.H., Bordignon, C., Assael, B.M., Conese, M. Comparison between cationic polymers and lipids in mediating systemic gene delivery to the lungs. Gene Ther. 1999, 6, 1995-2004.

${ }^{113}$ Chollet, P., Favrot, M.C., Hurbin, A., Coll, J.L. Side-effects of a systemic injection of linear polyethylenimine-DNA complexes. J. Gene Med. 2002, 4, 84-91.

114 Fahrmeir, J., Gunther, M., Tietze, N., Wagner, E., Ogris, M. Electrophoretic purification of tumor-targeted polyethylenimine-based polyplexes reduces toxic side effects in vivo. J. Contr. Rel. 2007, 122, 236-245.

115 Epstein-Barash, H., Gutman, D.,Markovsky E., Mishan-Eisenberg G., Koroukhov N., Szebeni, J., Golomb, G. Physicochemical parameters affecting liposomal bisphosphonates bioactivity for restenosis therapy: Internalization, cell inhibition, activation of cytokines and complement, and mechanism of cell death. J. Contr. Rel. 2010, 146, 182-195.

${ }^{116}$ Clarke, S.J., Rivory, L.P. Clinical pharmacokinetics of docetaxel. Clin. Pharmacokinet. 1999, 36, 99-114.

${ }^{117}$ Sonpavde, G. Abiraterone and increased survival in metastatic prostate cancer. N. Engl. J. Med. 2011, 365, 766-767.

118 Anderson, W., Kozak, D., Coleman, V.A., Jämting, Å.K., Trau, M. A comparative study of submicron particle sizing platforms: accuracy, precision and resolution analysis of polydisperse particle size distributions. $J$ Colloid Interface Sci. doi: 10.1016/j.jcis.2013.02.030. 2013.

119 Tomalia, D.A. In quest of a systematic framework for unifying and defining nanoscience. J Nanopart Res. 2009,11(6), 1251-1310. 
Lőrincz, O., Tőke, E.R., Somogyi, E., Horkay, F., Chandran, P.L., Douglas, J.F., Szebeni, J., Lisziewicz, J. Structure and biological activity of pathogen-like synthetic nanomedicines. Nanomedicine: NBM. 2012, 8, 497-506.

121 Petrov, A.I., Khalil, D.N., Kazaryan, R.L., Savintsev, I.V. \& Sukhorukov, B.I. Structural and thermodynamic features of complexes formed by DNA and synthetic polynucleotides with dodecylamine and dodecyltrimethylammonium bromide. Bioelectrochemistry. 2002, 58, 75-85.

${ }^{122}$ Bloomfield V.A., Criothers DM., Tinoco I. Nucleic Acids: Structure, Properties and Functions; University Science Books, 2000, Sausalito, California, USA.

123 Tomac S. et al. Ionic Effects on the Stability of Peptide Nucleic Acid (PNA) Complexes. J. Am. Chem. Soc. 1996, 118, 5544-5552.

${ }^{124}$ Lőrincz, O., Lisziewicz, J. Transdermal immunotherapy with synthetic pathogen-like nanomedicines and its clinical application towards the cure of HIV. Handbook of Clinical Nanomedicine: From Bench to Bedside. Pan Stanford Publishing, Szerk.: Raj Bawa, Gerald F. Audette, ISBN 9789814316170 . Tördelés alatt.

125 Lisziewicz, J., Lörincz, O. HIV-specific immunotherapy with DermaVir, the first pDNA/PEIm pathogen-like nanomedicine. Eur. J. Nanomed. 2012, 4, 81-87. 